\title{
VIEJAS Y NUEVAS NECRÓPOLIS EN LA EVOLUCIÓN DEL PAISAJE FUNERARIO DE ILICI EN LA ANTIGÜEDAD TARDÍA
}

\author{
OLD AND NEW NECROPOLEIS IN THE EVOLUTION OF THE FUNERARY LANDSCAPE OF ILICI IN LATE \\ ANTIQUITY
}

\author{
ROBERTO LORENZO DE SAN ROMÁN \\ "Curatio funeris, conditio sepulturae, pompa exequiarum, \\ magis sunt vivorum solatia quam subsidia mortuorum" \\ Aurelius Augustinus (De civitate Dei, 1, 12)
}

\begin{abstract}
Resumen. A partir del análisis de documentación inédita de P. Ibarra y A. Ramos, y revisando la escasa información publicada al respecto, este trabajo defiende que la Colonia Iulia llici Augusta tuvo, al menos, cinco necrópolis en un radio de $1500 \mathrm{~m}$ en la Antigüedad tardía. Tres de ellas se organizaron a lo largo de un mismo eje viario norte-sur, probablemente la propia via Augusta y cardo máximo de la centuriación ilicitana, y dos necrópolis intramuros alteraron el urbanismo anterior y el paisaje funerario de la colonia.
\end{abstract}

Palabras clave. Antigüedad tardía, llici, necrópolis, paisaje funerario.

\begin{abstract}
By analyzing P. Ibarra and A. Ramos' unpublished documents, and reviewing the limited information published on the subject, this work asserts that there were at least five necropoleis within a $1500 \mathrm{~m}$ radius of the Colonia Iulia Ilici Augusta in Late Antiquity. Three were located on the same north-south road, probably the via Augusta, which was the cardo maximus of llici's centuriation, and two cemeteries were within the city walls, changing the previous layout of the city and the colony's funerary landscape.
\end{abstract}

Key Words: Late Antiquity, Ilici, necropoleis, funerary landscape.

A la hora de intentar una aproximación arqueológica al mundo de la muerte y los rituales de enterramiento en la Colonia lulia llici Augusta (I'Alcúdia d'Elx) ${ }^{1}$, nos encontramos con que "[...] los cementerios de la antigua llici son escasamente conocidos al igual que su ubicación en la estructura urbana. Las noticias son escasas o confusas, y cuando conocemos algunos materia-

1. Una introducción historiográfica en las obras de: Jocelyn Toynbee (1971) sobre antecedentes, creencias, ritos y características formales de las tumbas y necrópolis romanas; Jean Prieur (1986), con referencias a ritos, monumentos, simbolismo funerario y el más allá; Javier Arce (1988), exhaustivamente centrado en los emperadores y el simbolismo político de sus funerales; Juan Manuel Abascal (1991), para aspectos legislativos y su paralelo arqueológico; y Ricardo González Villaescusa (2001 y 2003), para un anàlisis ideológico a partir de la realidad material de los ejemplos conocidos en el País Valenciano. Vid. también un reciente resumen divulgativo de Lorenzo Abad y Juan Manuel Abascal (2003) sobre necrópolis y ritos funerarios romanos en tierras valencianas, así como otro de María Luisa Ramos (2003) para Hispania. les no podemos precisar su lugar de procedencia" (González, 2001, 396). El desconocimiento de la posición y la relación entre las distintas tumbas, de las medidas de algunas y las relaciones estratigráficas de todas, pero también de los ajuares con un cierto detalle, de las posiciones y características físicas de los cadáveres, o incluso de la ubicación exacta de las necrópolis, todo ello vuelve una tarea casi imposible la correcta atribución cultural y cronológica de las áreas cementeriales de Ilici.

Este trabajo plantea la necesidad de recuperar para la investigación actual la información hasta ahora fragmentada y/o desconocida sobre las necrópolis ilicitanas, si bien centrado en el análisis de aquellas encuadrables en momentos tardíos, es decir, los siglos IV al VIII. Hablar de viejas y nuevas necrópolis adquiere aquí un doble sentido, puesto que no sólo se añaden algunas hasta ahora desconocidas para la historiografía ilicitana sino que se demuestra que hubo en Ilici necrópolis altoimperiales que siguieron en uso, o bien se reutilizaron, en la Antigüedad tardía. 
Por otra parte se combina la doble acepción de "viejas y nuevas necrópolis" con el "paisaje funerario tardío" y, pese al interés que éste último ha despertado en la historiografia reciente -con importantes congresos los últimos años (e.g. Gurt y Ribera, 2005)-, son escasos los trabajos centrados en esta época de $l l i c i^{2}$. Aquí se propone una primera aproximación a sus necrópolis ${ }^{3}$, con el objetivo de concretar tanto su número y ubicación como una estimación del total de individuos y sus rituales de enterramiento, para que futuros hallazgos e investigaciones puedan acercarnos progresivamente a la realidad del paisaje funerario -y de la mentalidad e ideología de la sociedad humana que lo crea- de llici en la Antigüedad tardía.

\section{BASE EMPÍRICA}

\subsection{Fuentes publicadas}

En este punto constatamos un desolador vacío historiográfico pues las únicas fuentes publicadas $^{4}$-las cuales se reproducen a continuación por no suponer textos demasiado largos y resultar

2. La historiografia tradicional no ha mostrado interés por las últimas fases de llici, las correspondientes a la Antigüedad tardía hasta su desaparición en el siglo VIII. A lo largo del siglo XX se ha escrito mucho sobre el cristianismo y la basílica descubierta en 1905, pero no es hasta la década de 1990 cuando surge la primera aportación arqueológica sobre la transformación tardoantigua de un sector de la ciudad (Molina y Poveda, 1995), así como diversos trabajos sobre la cerámica (Reynolds, 1993; Gutiérrez, 1996; Abad et alii, 2000), la basílica (Márquez y Poveda, 2000; Poveda, 2000, Lorenzo, 2005) o las necrópolis (González, 2001). Estas reflexiones han facilitado la actualización del yacimiento de acuerdo a modernos criterios científicos (vid. Abad y Hernández, 2004) con la aparición del primer gran revulsivo al desinterés anterior (Gutiérrez, 2004), de algunas consideraciones sobre la evolución del urbanismo (Tendero y Lara, 2004; Poveda, 2005), y de la primera monografía sobre la llici tardía (Lorenzo, 2006).

3. Y se propone una denominación de las mismas de acuerdo al aprovechamiento tradicional de la microtoponímia local para "bautizar" tanto necrópolis como yacimientos en general. Tendremos así necrópolis que hacen referencia al propietario de las tierras en que aparecieron -necrópolis del Torrero o del Tio Peix-, pero también a la realidad geográfica -necrópolis del Borrocat, del Campo de Experimentación Agrícola- o a la especial ubicación de las mismas -necrópolis de la basílica-

4. Existe una tercera fuente, que será analizada en su momento, pero no se transcribe aquí por hacer referencia a una única sepultura, "enclavada en el centro de la antiquísima ciudad", estudiada por Bernardo Morales en 1887, y presentada al Archivo de Roque Chabàs aquel año (Morales, 1888). interesante su análisis directo- son dos: el compendio sobre Ilici de Aureliano Ibarra de 1879 y las memorias de excavación de Alejandro Ramos sobre sus campañas de los años 1950-1954.

Anterior en el tiempo, Aureliano Ibarra (1879, 167-168), nos transmite haber excavado en 1856 un conjunto de sepulturas al norte de la loma:

"¿Tiene nada de extraño, [...] que, inmediatamente que descendemos de la Alcudia, hácia el norte de ésta, encontremos los enterramientos de sus antiguos habitantes? En vez de causarnos extrañeza, debemos hallarlo muy natural, sirviendo además para demostrarnos que por aquel sitio, se dilataba una de las principales vías de la ciudad, por cuanto por aquella parte se establecieron los sepulcros [...].

Son dignos de mención primeramente, entre los que hemos hallado, por ser los más toscos y sencillos, unos enterramientos construidos de sillares medianamente labrados, que dejaban un espacio bastante holgado para la colocación del cadáver: dos grandes piedras, algunas, de una longitud mayor de $2 \mathrm{~m}$, un ancho de 0'80 m, y un espesor de 0'40 m, formaban las paredes laterales; $y$ otras dos piedras, una colocada sobre el testero, y otra sobre los piés, encajando en una ranura de las laterales, cerraban el cuadrilongo, que tenía por cubierta, tres grandes ladrillos de 0'90 m cuadrados cada uno, por 0'08 m de espesor, los cuales, conservaban la huella de los dedos del alfarero, impresa en toda la superficie, en forma de $X$ al fabricarlos.

Otros enterramientos descubrimos, que en vez de las grandes piedras que dejamos mencionadas, tenían muros de mampostería, pero cubiertos con el mismo género de ladrillos; debiendo advertir, que tanto en unos como en otros, existía sobre los ladrillos, un maciso de cal y canto, de un espesor de 0'45 m. ¿Acaso este maciso, podría servir de cimentación bastante sólida y segura para elevar sobre el nivel del suelo algún modesto monumento?

Es de notar, que en el interior de alguno de estos sepulcros, se encontraban varios clavos de hierro, algunos de los cuales, adheridos por el rovin sobre la superficie interior de las paredes, por la parte de su cabeza, y toda la pua del clavo, hácia el centro; causándonos tal posición en el primer momento cierta extrañeza, que desapareció bien pronto, al observar en algunos de ellos, resíduos de madera, que demostraban, que los cadáveres se habían depositado encerrados en cajas de dicha materia, sobre las que se había hecho la obra, ó colocado las piedras de que antes dimos cuenta, para mejor resguardarlos sin duda.

Otros sepulcros, consistian en un gran trozo de piedra, regularmente tallada, con una cavidad bastante para contener el cadáver, y los cuales se cubrían con una desmesurada losa, que ocupaba toda la extensión de aquellos toscos sarcófagos.

En ninguno de estos sepulcros, hecha excepción de algunos restos humanos, de que guardaban ciertos vestigios, se hallaba cosa digna de mención especial, excepto alguna que otra cáscara de huevo; y sólo en uno, encontramos una redomita de vidrio, colocada entre los huesos de las piernas del esqueleto, que en este sepulcro se encontraba bastante entero, y la cual, debió servir de vaso lacrimatorio, ó para contener cualquier esencia [...].

Contigüo á donde aparecian los modestos enterramientos ya mencionados, y entre los que dejamos de de- 
cir, hallamos vasos ó urnas de tierra cocida, conteniendo cenizas y ánforas cortadas longitudinalmente, en el interior de las que se hallaban restos humanos [...]"

Por su parte, Alejandro Ramos reexcavó la basílica -descubierta en 1905- y su entorno norte en 1948 (Ramos, 1954) y dedicó los dos años siguientes a ampliar la excavación al sur y al este del edificio absidado (Ramos, 1956 y 1962). A finales de 1950 avanzó, pues, al este, desde el ábside hacia el caminal de entrada a su casamuseo, actualmente asfaltado, y excavó un conjunto de sepulturas muy superficiales, con restos de cinco individuos (Ramos, 1956, 107):

"Apenas comenzamos a cavar y a una profundidad de 25 centímetros de la superficie, o sea en pleno nivel agrícola, observamos la aparición de unos huesos, que descubiertos con el cuidado que el caso requería, nos mostraron la existencia de varios esqueletos casi completos, en número de cuatro, orientados de Este a Oeste, más los huesos de las piernas de otro, y todos ellos deteriorados seguramente a causa de las labores agrícolas, dada su proximidad a la superficie, razón por la cual deben haber desaparecido otros esqueletos de esta supuesta necrópolis visigoda $[\ldots]$

En ninguna de estas sepulturas se han encontrado restos ni huellas de madera, clavos ni otros indicios de cajas o féretros para su enterramiento; es más, las fosas excavadas para inhumar los cadáveres eran de dimensiones reducidas. Este conjunto de observaciones nos hace suponer que los cadáveres, tal vez envueltos en simple sudario, fueron colocados en las fosas y cubiertos de tierra, de forma que probablemente a simple vista pudieran localizarse las sepulturas.

La modestia de estas sepulturas se manifiesta asimismo en sus ajuares, que casi no existían, pues sólo se han encontrado fragmentos de vasijas muy bastas, y tan sólo junto a uno de los cráneos y en el lugar correspondiente a las orejas había unos pendientes en forma de aro y con un adorno perforado de pasta vítrea. [...]. Este reducido número de sepulturas, conservado por hallarse entre árboles viejos, creo son parte de una necrópolis visigoda destruída por las labores agrícolas, necrópolis que corresponde a la última época en que estuvo poblada La Alcudia y que corresponde al tipo de las de Herrera del Pisuerga, Castiltierra y Villel de Mesa, y cuya cronología se puede calcular que corresponde a los siglos VI-VII después de J.C."

Años más tarde, en publicaciones de carácter general Alejandro Ramos recuperó la noticia de la necrópolis de la basílica y precisó algún punto como la posición de las cabezas "a levante" (Ramos, 1970, 84), y también modificó la profundidad en que debió aparecer alguna de ellas, "a poco más de diez centímetros de la superficie" (Ramos, 1974, 121).

Finalmente, el propio Alejandro Ramos excavó también entre los años 1952 y 1954 una tercera necrópolis en el llamado sector 6-F de l'Alcúdia, al sur del caminal de acceso a su casa desde el camino del Borrocat, y al norte de las
Termas Orientales excavadas recientemente, y presentó los resultados en dos memorias de excavación. Alguna fotografía y una introducción en la correspondiente al año 1952 (Ramos 1956, Lám.CIX), en cuyos pies de foto indicaba "enterramientos, posiblemente visigodos", y nuevas descripciones de tumbas y ajuares en la correspondiente a 1953 (Ramos 1962, 91):

"Al lado [en las tierras sitas al sur del caminal que conduce al camino del Borrocat y al linde de la finca] había un piso de argamasa, sobre el que había varias losas, que delataba la existencia de unas sepulturas, que una vez descubiertas mostraron una de ellas dos esqueletos y uno en la otra, pero sin ajuar alguno" (Ramos, 1956, 113).

"[...] Arrancando el piso de época romana tardía que conservaba restos de estucos en sus paredes [...] y continuada la excavación, encontramos una construcción de tipo funerario [...] saqueada de antiguo, sin que en ella hayamos encontrado resto alguno. En ella había aún dos huecos cubiertos, en parte todavía con grandes ladrillos cuadrados, que por su forma nos hace pensar fueron sepulturas. La obra es de un cemento bien enlucido en las paredes y el piso. Otra razón para considerar de tipo funerario este monumento es que alrededor de él y en su mismo nivel, hemos encontrado varias sepulturas, todas ellas construídas con losas de sillería los lados y cubiertas con otras iguales [...]. Una de ellas conservaba su ajuar, integrado por un collar de cuentas de vidrio y espinas de pescado, unos pendientes de cobre con adornos de vidrio uno de ellos [...] y varios anillos de cobre y hierro, así como un botón [...]. Otra también tenía un collar, compuesto de cuentas de vidrio y ágata, y varios anillos de cobre [...], ajuares de factura romana tardía" (Ramos, 1962, 91-92 y Láms.LXX-LXXI-LXII).

Y, de nuevo en publicaciones de carácter general (Ramos, 1970 y 1974), posteriormente amplió algo la información sobre esta necrópolis del sector 6-F y le propuso una cronología del siglo $\mathrm{V}$ :

"También hemos localizado en La Alcudia una necrópolis de esta época [siglo V]. Las sepulturas estaban formadas por varias losas verticales y como tapadera en algunas ocasiones se utilizaban ladrillos de grandes dimensiones, de forma cuadrada. También las había abiertas en un gran bloque de piedra en el que habían hecho el hueco suficiente para alojar el cadáver, siendo en este caso la tapadera de una sola pieza. Por regla general carecían de ajuar funerario, revelando con ello el influjo del cristianismo, y tan sólo en dos sepulturas femeninas hallamos las modestas alhajas que usaron: sencillos anillos de bronce; pendientes del mismo metal y collares formados por cuentas, casi todas ellas, de pasta de vidrio. En esta necrópolis existía un monumento con pasillos, a cuyos lados, había varias sepulturas, todas ellas profanadas ya cuando se hizo la excavación, encontrándolas ya destrozadas. Estas sepulturas se hallaban cubiertas también con la misma clase de grandes ladrillos cuadrados, con un aspa hecha con los dedos cuando el barro estaba tierno" (Ramos, 1970, 74).

"De hacia el siglo $\mathrm{V}$ podemos considerar es una necrópolis hallada frente al edificio de la casa y actual Museo, en la que la mayor parte de las sepulturas se ha- 
llan formadas por losas verticales, de distintos tamaños, y cubiertas muchas de ellas por ladrillos rojos cuadrados, salvo una de ellas labrada la caja en piedra en una pieza así como la tapadera a dos vertientes. Casi todas ellas carecían de ajuar funerario, excepto dos de mujer que tenían su collar, pendientes y varios anillos" (Ramos 1974, 152)

Junto con alguna otra aislada y escueta referencia a la aparición de enterramientos en l'Alcúdia o sus inmediaciones, como los reseñados en la "Breve nota de mis Efemérides Arqueológicas llicitanas" de Pere Ibarra (1926, 155-166) o el "Mapa arqueológico del término municipal de Elche" de Alejandro Ramos (1953), ésta es toda la información publicada por los dos únicos excavadores de tumbas en llici que dejaron constancia escrita, Aureliano Ibarra y Alejandro Ramos, pues de las innumerables exploraciones y remociones de tierras que sufrió l'Alcúdia entre los siglos XVII y XIX apenas conocemos los nombres de unos cuantos participantes y algunos hallazgos. De manera que la información antes transcrita, incompleta y fuertemente descontextualizada -en parte por la antigüedad de las excavaciones y por la formación no arqueológica de ambos investigadores-, es la única que se ha repetido, fragmentariamente, en las distintas monografías sobre la historia de llici o del yacimiento de l'Alcúdia aparecidas en los últimos cincuenta años ${ }^{5}$.

\subsection{Material inédito}

Recientemente traté la problemática que envuelve a la basílica cristiana y los enterramientos adyacentes (Lorenzo, 2005) como avance a una revisión de conjunto de la llici tardía en que se ordena la información publicada sobre los enterramientos conocidos y excavados de antiguo en l'Alcúdia (Lorenzo, 2006, 86-93). Pero, posterior a la fase de redacción de dichos trabajos, el acceso a nuevos datos inéditos ha venido a enriquecer $\mathrm{o}$, en algún caso, matizar y corregir varias de las ideas que en ellos aparecían, motivando la presente reflexión. La consulta de los diarios de excavación de Alejandro Ramos de los años 1948 a 1954, y de croquis y notas suyas y de Pere

5. Así, por ejemplo, en la obra de Rafael Ramos sobre el conjunto de la llici romana $(1975,260)$, quien sólo habla de la necrópolis de la basílica y olvida la del sector 6-F, o en la "actualización planimétrica" de Alejandro Ramos (1997, 27-28), quien de la ciudad "reconstruida a partir de la invasión de los francos y que perduró hasta la invasión de los bárbaros a principios del siglo V" destaca la basílica y la necrópolis del sector $6-\mathrm{F}$, pero sin mencionar la necrópolis de la propia basílica.
Ibarra conservadas en el Museo Monográfico "La Alcudia" ${ }^{\prime \prime}$, unida al análisis de una serie de planos y fotografías inéditas de la basílica tomadas por un equipo del Instituto Arqueológico Alemán de Madrid en $1971^{7}$, así como la información generada por unas excavaciones de urgencia en 2003 al sur del camino del Borrocat, a levante de la loma ${ }^{8}$, han completado en gran medida la escasa información de que disponemos para la correcta interpretación del fenómeno de los enterramientos urbanos en la llici tardoantigua.

En primer lugar mencionaré el agradable descubrimiento en el Archivo de la Fundación l'Alcúdia (AFA) de una pequeña parte de las Efemérides llicitanas de Pere Ibarra ${ }^{9}$, manuscritas o mecanografiadas y reunidas por Alejandro Ramos -quien tuvo acceso al documento original como archivero de Elche entre 1940 y 1974, e hizo profusamente uso del mismo-. Estas Efemérides, recopiladas probablemente en la década de 1950 cuando Alejandro Ramos investigaba los enterramientos que le aparecían en el sector

6. Cortesía de sus descendientes el Dr. Rafael Ramos Fernández y Alejandro Ramos Molina, y de la Fundación Universitaria de Investigación Arqueológica "La Alcudia" -www.laalcudia.uafg.ua.es-, a quienes aprovecho para agradecer la oportunidad brindada.

7. Cuya consulta y reproduccion debo agradecer tanto a la amabilidad de la directora del Instituto Arqueológico Alemán de Madrid -www.dainst.org/abteilung.php?id=267-, la Dra. Dirce Marzoli, como a la de Laureano de Frutos, participante que fue de aquella expedición de 1971 en que se tomaron las únicas cotas existentes sobre los restos de la basílica, entonces ya reexcavada, y se realizó la única planta rigurosa publicada (Schlunk y Hauschild, 1978, 9), y quien me facilitó abundante información gráfica sobre el monumento por ellos dibujado. Agradezco también al Dr. Theodor Hauschild, autor de las fotografias sobre la basílica en aquella expedición, su tiempo, amabilidad y consejos.

8. Excavaciones realizadas por el equipo arqueológico que dirige Eduardo López Seguí, "Alebus S.L Patrimonio Histórico" -www.alebusph.com-, quien tuvo la amabilidad de enviarme el material inédito generado por aquella intervención de urgencia.

9. En palabras de Joan Castaño, quien mejor ha estudiado la obra de Pere Ibarra, "Aquestes Efemérides ilicitanas, [...] eren una mena de diari que va iniciar Ibarra l'any 1870 que fins a 1923 -última de les dates publicades en el llibre Elche: materiales...- abastava 1.773 notícies. Malauradament, els diversos volums que formaven aquesta collecció de notícies, sens dubte de trascendental importància per a conèixer la història de la ciutat en l'últim terç del segle XIX i el primer del XX, no estan actualment localitzats, encara que sí que figuren en l'inventari de la biblioteca Ibarra de l'any 1935. Trenta-tres fulls amb esborranys d'aquestes efemèrides es conserven en l'AHME (Manuscrits de P.Ibarra, lligall M/8, núm.1)" (Castaño, 2002, 191). 
6- $\mathrm{F}^{10}$, así como algunos borradores de otras Efemérides conservados en el Arxiu Històric i Municipal d'Elx (AHME) -vid. nota 9- nos transmiten la aparición de varios enterramientos en la loma de l'Alcúdia y cercanías a lo largo de los casi cuarenta años que median entre 1887 y 1925 :

Agosto de $1887^{11}$.

Se descubre una sepultura en la Alcúdia, cerca de la piscina. Cinco sillares formando la cubierta que suman en junto, 2'40 metros. Largo de sillar, 1,23 metros.

Dimensiones de la sepultura. Longitud 2,23, Ancho 0'60, Honda 0'75.

15 de agosto de $1895^{12}$.

Vengo de la Alcúdia, de ver una sepultura que descubrieron ayer a última hora. He entrado en ella y espero escarbarla mañana a primera hora, antes de que vengan los trabajadores.

Efectivamente: hoy 16 me he personado en la Alcúdia y por mi propia mano he registrado la sepultura. El hueco está perfectamente conservado y rebocado de cal, tiene la tapadera por poniente, por medio de una gran losa. La cubren cuatro losas y (encima) una fuerte capa de hormigón y piedras, al exterior. El suelo también está enlucido. Ningún objeto. El cadáver estaba colocado de poniente a levante, con los pies hacia este punto, $\mathrm{y}$, únicamente me he traído gran cantidad de clavos de hierro ( $\mathrm{n} .142$ del catálogo) a los cuáles permanece unida porción de materia que bien parece madera, y con los cuales estaría construida o clavada la caja. El esqueleto, completo, me he traido el cráneo.

Dimensiones de la sepultura: Longitud. 2'60 - anchura: 0'64. Profundidad: 0'85.

8 de octubre de 1897. Efeméride $126^{13}$.

A poniente de la casita de la loma unos 8 metros, se han eneontrado hallado dos sepulturas de piedra. En una de ellas había todavía, el esqueleto, en perfecto estado de conservación. Se ha encontrado en la misma, una sortija de plata, sin otro adorno que una marquita indescifrable, por lo borrosa"

10. Parte de la información proporcionada por estas efemérides inéditas sobre hallazgos en el Camp d'Elx fue extractada como noticia breve por Alejandro Ramos en su Mapa arqueológico del término municipal de Elche de 1953, y así recogida luego por Paul Reynolds (1993, 59-69), generalmente con una anotación de "unlocated" superada en este trabajo.

11. AHME, nota de Pere Ibarra. Otra versión conservada en el AFA dice: "Alcudia: Sepultura de argamasa, cubierta de grandes sillares, cerca de la gran "piscina". En la sepultura se encontró un plato saguntino y una moneda de cobre. Bernardo Morales San Martín.- Sepulcro romano en Illici. El Archivo, tom $2^{\circ}$ pag.111. Denia 1887 y 1888."

12. AHME, nota de Pere Ibarra.

13. AHME, nota de Pere Ibarra. Referenciada en la Breve nota de mis Efemérides Arqueológicas Illicitanas (Ibarra, 1926, 155): "De 6 Agosto a 8 de Octubre 1897: Excavación en la loma: hallazgo de dos sepulturas: algunos objetos".
13 de junio de 1898. Efeméride $147^{14}$.

Esta tarde he recibido la visita de Monsiéur Paris con Don Pascual Serrano de Bonete.

Hemos estado en la Alcúdia, donde están cavando para sembrar alfalfa, al norte, lindando con los olivares de Rojas, donde han salido, revueltos en la tierra, muchos huesos y un cráneo humano [...].

3 de junio de 1900 . Efeméride $247^{15}$.

Al Norte de la loma de la Alcúdia, en tierras del torrero, en las mismas que años atrás (1857), halló Aureliano una cripta subterránea de cantería, con bajada de escalera (IIlici, lámina XIII) se han encontrado algunas sepulturas muy a la superficie del terreno. He visto huesos de 3 esqueletos. Me he traído un cráneo de muger (número 144) perfectamente conservado. Por el carácter que presentan las sepulturas, parecen de romanos. El subsuelo queda intacto, pues el dueño, Antonio Esteve, no quiere ahondar, pues me dice que está muy obstruido de la obra antigua y piedras.

30 de enero de 1905. Efeméride 464. Hallazgo en Carmahadet $^{16}$.

En una finca propia de Ramon Espinosa Tari en Carmahadet ha sido hallada una sepultura al parecer romana. Estaba formada por un rectangulo de doble fila de sillares asentados sobre una gruesa capa de canto rodado y otras piedras sueltas. No he podido medirla por que cuando la he visto ya la habian destruido. Los sillares miden desde 1 metro hasta $1 ' 20 \mathrm{~cm}$. Objetos sueltos solo he recogido dos vinagreras de bronce.

11 de febrero de 1907. Efeméride 562. Hallazgo en la hacienda de Porter ${ }^{17}$.

En la hacienda de Porter propiedad de Ramon Irles Candela se ha encontrado éste cavando una sepultura romana. Varios huesos humanos, dos monedas de bronce de las cuales he podido adquirir una que es de Filipo el Padre y lo de más merito un fragmento de una inscripcion lapidaria en marmol blanco veteado de verde que es esta:

$D^{*}$

$M^{*} P U B L^{*}$

ET M*PUBL*

14. AHME, nota de Pere Ibarra.

15. AHME, nota de Pere Ibarra. Referenciada en la Breve nota de mis Efemérides Arqueológicas Illicitanas (Ibarra, 1926, 156): "3 Junio 1900.- Hallazgo en la Alcudia: sepulturas".

Esta misma nota se encuentra mecanografiada en el AFA: "Al N. de la loma de la Alcúdia en tierras del torrero las mismas que años atrás hallo Aureliano una cripta subterranea de canteria este se ha encontrado algunas sepulturas muy a la superficie. He visto huesos de tres esqueletos. Me he traido un craneo de mujer perfectamente conservado. Por el caracter que presentan las sepulturas parecen de romanos. El subsuelo queda intacto pues el dueño, Antonio Esteve no quiere ahondar y me dice que está muy obstruido de obra antigua y piedra".

16. AFA, nota de Pere Ibarra mecanografiada.

17. AFA, nota de Pere Ibarra mecanografiada. Referenciada en la Breve nota de mis Efemérides Arqueológicas Illicitanas (Ibarra, 1926, 157): "11 Febrero 1907.- Hallazgo interesante de una sepultura romana, lápida y dos monedas de bronce en la hacienda de Porter". 
15 de agosto de 1909. Efeméride 656. Restos humanos en enterramientos hallados en el barrio nuevo del teatro Llorente ${ }^{18}$

En la calle de Velarde (nueva del teatro Principal o Llorente) en la tercer manzana a mano derecha se han encontrado restos de enterramientos antiquisimos. EI dueño de la casa en construccion, esta haciendo una profunda excavacion en el ángulo izquierdo a la entrada para abrir un pozo en cual recoger las aguas llovedizas. A una profundidad de tres metros han hallado los cavadores diferentes osamentas humanas ordenados en serie de tres en tres y superpuestos en lineas de levante a poniente, aislados con tejas romanas puestas de plano, una a continuacion de la otra. De los restos lo mejor conservados son los craneos y algunos fémures y costillas. No han encontrado ningun objeto.

11 de octubre de 1914. Efeméride 1120. Sepultura cerca de la Alcudia junto al Borrocat ${ }^{19}$.

En la excavacion practicada para abrir un nuevo partidor que llevara el $n^{\circ}[\mathrm{sic}]$ en la tercera elevacion "brazo de levante" a levante de la Alcudia se ha descubierto una sepultura romana. Los muretes son de manposteria el piso de ladrillo cuadrado de 0 ' $23 \mathrm{~cm}$ y estaba cubierto de 4 ladrillos cuadrados de 0'63 de lado.

Largo sepultura 2'35 Ancho 0'50 profundidad 0'50. abierta a $1 \mathrm{~m}$ del piso del bancal.

Según me informan solo contenia huesos. He recogido algunos y dos ladrillos uno de cada tamaño.

24 de diciembre de 1915. Efeméride 1206. Sepultura en La Hoya ${ }^{20}$

Hallazgo en La Hoya. Un labrador llamado Francisco Guilló, por apodo el Fortet de Guilló, practicando ciertas labores en un bancal de su propiedad ha encontrado una sepultura de grandes dimensiones, cubierta con cinco losas de canteria. Aun conservaba el cadaver, cuya vestimenta se deshizo al contacto del aire, y no ha podido conservar mas que los zapatos con grandes tacones. Con el fin de poder enseñarlo, lo ha vuelto a cubrir otra vez. Revueltos en la tierra, varios objetos: Una moneda de oro, Constantino iiii de la que ha tomado esta impronta. Haré por visitar aquello.

A) Cab a derecha. Constantinus Aug

R) VOTISV MULTIS A

Exergo PTB
18. AFA, nota de Pere Ibarra mecanografiada. Adjunta una fotografía fragmentada de dos ladrillos cuadrados con digitaciones en aspa apoyados contra una pared de tierra. Nota referenciada en la Breve nota de mis Efemérides Arqueológicas Illicitanas (Ibarra, 1926, 158): "5 Agosto 1909.- Restos humanos, antiguos, en la Calle de Velarde".

19. AFA, nota de Pere Ibarra mecanografiada. Referenciada en la Breve nota de mis Efemérides Arqueológicas Illicitanas (Ibarra, 1926, 160): "11 Octubre 1914.- Sepultura romana junto a Alborrocat".

20. AFA, nota de Pere Ibarra. Referenciada en la Breve nota de mis Efemérides Arqueológicas Illicitanas (Ibarra, 1926, 161): "24 Diciembre 1915.- Sepultura antigua, en la Hoya".
9 de marzo de 1916. Efeméride 1221. Sepultura en Daimés ${ }^{21}$.

En la hacienda llamada de "Diego Sempere" en Daimes, hoy propiedad de Agustín Agulló (a) el peix, preparando un bancal para alfalfa se ha encontrado Agustín un interesante grupo de sepulturas prerromanas. Cuatro de ellas estan formadas con dos mitades de ataud de piedra de canteria, toscamente labrada; y varias otras formadas con losas colocadas en el suelo y otras verticales formando hiladas. La orientación de los esqueletos, todos, la cabeza hacia "la Cartagena". Objeto suelto ninguno tan solo unos fragmentos pequeños de hierro tenia un cadaver a su derecha, dentro de una de las de piedra. Tres fragmentos de piedra labrada he recogido del enorme montón de piedras sueltas y tejas rotas. Dos de estos son del mismo estilo que cierta ventana calada que se hallo en la excavación de la Alcudia por Albertini: Son una columnita, a modo de parteluz, y el arranque de los arquitos; y un trozo, con ambas superficies labradas, diseñando parte de unas alas o pliegue de ropaje. El tercer fragmento es de un pequeño friso con estrias triangulares.

[dibujo] Dimensión interior: ancho cabecera 0'38 metros, ancho pies 0'27 longitud 1'22 profundidad 0'20. Dos iguales en tamaño y otras dos mayores de igual forma 0'35 x 1'70 x 0'20.

Todas conservaban algunos huesos; y una de las dos pequeñas, el estado de conservación era mas completo pues de haberse extraido el esqueleto con precaución, se hubiera obtenido entero.

Todas las tapas, conpuestas de tres losas las grandes y dos las pequeñas. En una de aquellas, en la cara interior que corresponde a la cabecera de la sepultura tiene grabada en hueco, rusticamente, una muesca o concavidad circular, con boquete de salida en esta forma: [dibujo]

La vecina del ventorrillo de Carabanes me ha cedido un Honorio de hierro forrado de oro hallado alli cerca.

El grueso de las tapas de unos 0'10 m poco mas o menos. Registrada la tierra por los operarios nada hallaron que les llamara la atención. Dias despues he ido y repasado bien aquello y solo he recogido las piedras de que antes hago mención.

Me traigo esta sepultura hoy 5 de mayo de 1916 y la piedra. (La cursiva es mía).

3 de marzo de 1917. Efeméride 1294. Más restos en tierras de Peix ${ }^{22}$

Me participa mi amigo Agustin Agullo (El Peix) haber reanudado la cava al norte del bancalillo donde halló la caja de piedra (ver efemeride $n^{\circ} 1221$ ). Ha encontrado otra cavando al $\mathrm{N}$. donde le indiqué. Muchos trozos de canteria y no pocos tiestos de tejas arabes, esto es de las curvadas. Objeto interesante ninguno.

21. AFA, nota de Pere Ibarra, referenciada en la Breve nota de mis Efemérides Arqueológicas Illicitanas (Ibarra, 1926, 161): Efeméride 1221: "9 Marzo 1916.- Sepulturas en Daymés" y Efeméride 1228: " $1^{\circ}$ de Mayo 1916.- Honorio, de hierro con forro de oro, en Daymés. Regalo de una sepultura". También en AFA aparece mecanografiada con ligeras variantes, como recojido por recogido, así como con varios añadidos, aquí remarcados en cursiva, y sin los dibujos.

22. AFA, nota de Pere Ibarra mecanografiada. 
29 de enero de 1918. Efeméride 1381. Safarix en la hacienda de R. Irles ${ }^{23}$.

En la hacienda de Ramon Irles, cavando la era para plantar un jardin han sacado los cavadores algunos restos interesantes. Una rulera de argamasa con muretes laterales de N. a S. con todas las apariencias de un safarix, una losa de piedra con señales evidentes de haber sido hogar de algo, restos ceramicos romanos, tejas y dolianos. Una vasija, entera, en forma de botella emseada [subrayado, quizás anseada], la rompieron, huesos humanos esparcidos entre ellos un craneo.

26 de enero de 1925. Efeméride 1928. Hallazgo de sepulturas ${ }^{24}$

En la Alcudia, con motivo de estar haciendo hoyos para plantar arboles se han encontrado algunas piedras interesantes, sobre todo, sillares con diversas tabores labores. La pieza mas importante es un ataud que conservava los huesos de los dos difuntos, por que son dos los craneos.

Las dimensiones son estas: Longitud 2'17, ancho 47 y 32. Ningun testimonio ni objetos. Piedra franca.

6 de febrero de 1925. Efeméride 1931. Más sepulturas ${ }^{25}$. En la Alcudia han salido tres nuevas cajas de piedra en el mismo punto donde se encontraron la caja el dia 26 de Enero ultimo. El bancal está enfrente de la casa, linde del caminito del jardín.

20 de febrero de 1925. Efeméride 1935. Objeto de vidrio $^{26}$.

En el interior de una de las cajas de piedra, que se encontraron en la Loma, (Ver efemeride n. 1928) han encontrado una especie de violetero o florero de vidrio muy interesante. Afecta la forma adjunta y su estado de conservacion es perfecto. Lo guarda la propietaria $\mathrm{S}^{\mathrm{a}} \mathrm{V}^{\mathrm{da}}$ de Ramos. Mide unos $121 / 2 \mathrm{cms}$.

Hasta aquí la información aportada por las Efemérides perdidas de Pere Ibarra, sin que de momento sepamos si había más noticias sobre enterramientos en ellas.

Como otra información inédita, y en segundo lugar, tenemos los diarios de excavación de Alejandro Ramos de las campañas 1948 a 1954, con datos sobre los enterramientos descubiertos en esos años y algunas precisiones no reflejadas en las memorias, y también existen numerosas fotografías parcialmente ordenadas sobre las necrópolis -varias de ellas ya publicadas en distintas obras de Alejandro y Rafael Ramos-. Pero la mayor sorpresa ha sido encontrar, entre los papeles conservados en el AFA, un croquis de la necrópolis excavada entre 1952 y 1954 en el sector 6-F con hasta diecisiete enterramientos

23. AFA, nota de Pere Ibarra. Referenciada en la Breve nota de mis Efemérides Arqueológicas Illicitanas (Ibarra, 1926, 163): "29 Enero 1918 .- Safarix antiguo en la Hacienda de R. Irles Gomis. Cerámica romana y restos de un hogar".

24. AFA, nota de Pere Ibarra.

25. AFA, nota de Pere Ibarra.

26. AFA, nota de Pere Ibarra. Falta el dibujo que se dice adjunto. numerados -si bien de los diarios se desprende la existencia de algunos otros-, todos alineados E-O, y adaptados a estructuras que parecen anteriores (Fig. 14). En el croquis se indican también los cuatro pozos manantiales excavados por Alejandro Ramos en aquellos años (Ramos, 1958) y así lo publicó Rafael Ramos $(1975,213)$ aunque únicamente referido a esos pozos y obviando toda información sobre una necrópolis para la que no se había precisado siquiera el número de enterramientos excavados.

De los diarios de excavación de Alejandro Ramos se obtiene una información irregular tanto por el detalle con que el autor recogía o despreciaba los datos que la remoción de tierras le proporcionaba, como también en cuanto a la continuidad temporal de las actuaciones en un mismo sector, mediatizadas por las necesidades agrícolas de la finca. Para el caso que ahora interesa hay alguna mención y/o croquis sobre las sepulturas excavadas en el sector 6-F desde que el 4 de abril de 1952 Alejandro Ramos comenzara con cuatro hombres "las excavaciones en el bancal al E. de la finca, que linda con P. Esclapez y camino que va al Borrocat, empezando por hacer una zanja en lo que llamamos la veleta o estribo de la finca, para observar la estratigrafía".

El primer mes se dedicó a esa gran zanja y al descubrimiento y excavación del primero de los pozos manantiales que aparecerían en la zona, y sólo a lo largo de mayo descubrió las primeras tumbas, dos de ellas paralelas: "Comenzamos en el bancal, junto al caminal que va al Borrocat y al este del jardín de frente a la casa. Encontramos la planta de una casa o mejor dicho, de una habitación, de unos $4 \times 8$, con piso de argamasa y los muros, unos 20 a 30 centímetros de altos, con estucos pintados muy bonitos" escribe Alejandro Ramos el 2 de mayo de 1952, y añade un primer croquis el día siguiente. Ampliando las excavaciones al sur de esa habitación, el 8 de mayo descubre un primer "enterramiento, cubierto de losas" alineado E-O con la cabeza a poniente y colocado en decúbito supino, según el correspondiente croquis en planta, y lo interpreta correspondiente al "nivel C" del yacimiento, aunque en una sección aparece en el nivel $B$ y sellado por una capa de argamasa que llegaría hasta la frontera con los estratos alterados por el laboreo agrícola.

Al sur y próximos al anterior aparecieron, entre el 12 y 13 de mayo, otros dos enterramientos también orientados al este, paralelos y separados entre sí por $1^{\prime} 10 m-n^{\circ} 1$ y $n^{\circ} 2$ en la planta general (Fig. 14)-. El más septentrional de $2 \mathrm{~m}$ de longitud, $50 \mathrm{~cm}$ de anchura en la cabecera 
y $40 \mathrm{~cm}$ en los pies, con las paredes y cubierta construidas con losas de $60 \mathrm{~cm}$ de longitud dispuestas transversalmente a la sepultura. El segundo, más pequeño, de 1'80 $\mathrm{m}$ de longitud por $50 \mathrm{~cm}$ de anchura en la cabecera y 40 en los pies, con las paredes construidas con losas de $50 \mathrm{~cm}$ de longitud y la cubierta con otras de $53 \mathrm{~cm}$ de longitud máxima y una disposición análoga. La cubierta de ambos enterramientos coincidía con un nivel de argamasa que regularizaba la zona, y que Alejandro Ramos sitúa en el nivel C, con una moneda de Licinio (307-324) sobre él, mientras que otra capa de argamasa, que corresponde al nivel $B$ del mismo esquema estratigráfico, regularizaba, a una cota superior, los estratos que cubrían las tumbas (Fig. 1).

Tras dedicar el resto del mes a excavar los niveles inferiores de esa zona, y a actividades propias de la finca agrícola que todavía era l'Alcúdia, como las colmenas o arreglar los caminales, no es hasta mediados de septiembre que Alejandro Ramos retoma las excavaciones, cerca y a poniente del extremo meridional de la gran zanja con que empezó el Sector 6-F, y menciona nuevas sepulturas en sus diarios. El 11 de septiembre aparece en un croquis la más occidental de todas -la $n^{\circ} 3$ en la planta general-, perpendicular y a 1'30 $\mathrm{m}$ de distancia de un muro que le queda al este, con 1'60 m de longitud y una cubierta de cinco losas, así como con una tegula dispuesta verticalmente como parte de la pared norte -aunque por la falta de la tercera dimensión en el croquis podría quizás interpretarse como único resto de una perdida superestructura-.

Tras varios días en que el diario registra "nada", el 18 de septiembre indica estar "Los niveles alterados en época romana tardía, como lo demuestran las sepulturas con cubiertas con losas y a los lados, ladrillos. De este nivel hacia abajo, todo removido". El mismo día registra un fragmento de losa de piedra labrada y "un vaso tosco, tardío" en ese nivel, y al día siguiente un croquis muestra las tumbas 4,5 y 6 de la planta general, así como una planta de la zona en que se sitúan los "niveles alterados en época romana", mientras que el 3 de octubre registra "cerámica basta tardía" en el nivel de las sepulturas, así como "dos moneditas (Claudio II)" (268-270).

Tras un nuevo parón, a principios de diciembre Alejandro Ramos regresó a la habitación de $4 \times 8 \mathrm{~m}$ con muros estucados descubierta medio año atrás. Excava una dependencia anexa al norte, con un pavimento sobre el que encuentra una moneda de Constantino I (306-337) al mis-

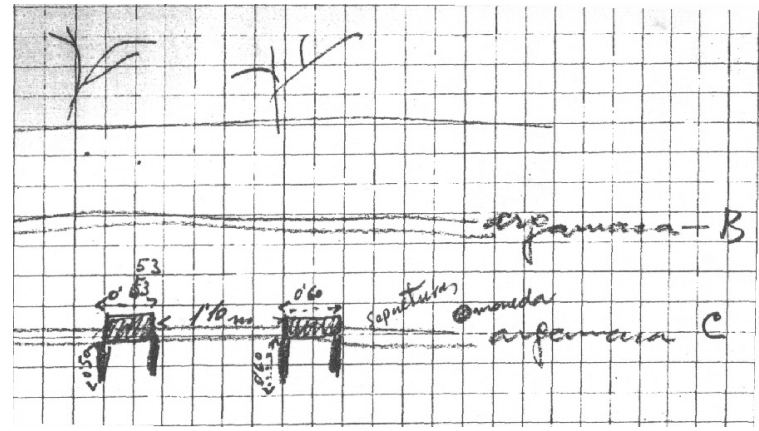

Figura 1: Croquis de A. Ramos de la sección de las tumbas 1 y 2 de la necrópolis del Borrocat.

mo nivel que el de la mencionada habitación, y también la zona inmediata al este, "encontrando el terreno removido, con escasos fragmentos de cerámica y trozos de piso de argamasa, y muchos trozos de tejas planas y curvas" (5-XII-1952), así como diversas paredes de adobe sobre un zócalo de piedra en un nivel inferior.

Entre el 16 y el 28 de febrero de 1953 "Comenzamos a cavar al sur de la calle empedrada, hasta el margen del bancal en que se halla la piscina, rota. Se descubren las paredes que se indican en el croquis de la libreta y varias sepulturas [números 4, 5 y 6 de la planta general]. Las sepulturas, hechas con residuos de materiales, ninguna contiene ajuar. Entre las losas que cubría una de ellas (fotos) hay una pieza así [dibujo]. [...] Es de notar que por bajo de las sepulturas, hasta el nivel $F, y$ a veces dos metros mas hondo del nivel de la tierra virgen, está cavado, no sé con qué fin, y por lo tanto, todo revuelto, apareciendo bajo del todo fragmentos de sigillata y de la cerámica basta de la última época del yacimiento. [...] [dibujo] Junto a los portales, un P.B. [i.e. pequeño bronce], nivel D (?) Constantino". Vemos claramente aquí que la división estratigráfica en niveles artificiales correspondientes a distintas fases cronoculturales del yacimiento conllevaba la eliminación de la lectura correcta del registro estratigráfico, de manera que el propio Alejandro Ramos remarca con un signo de interrogación el hecho de aparecerle un bronce de Constantino I (306-337) en el nivel D que él creía finalizado a mediados del siglo I dC. Óbviamente no se hallaba ante un "nivel D" sino delante de la compleja realidad estratigráfica de los últimos siglos de vida de llici, en que, a tenor de tantas referencias a estar "todo revuelto" quizá debiéramos empezar a suponer grandes operaciones de acarreo y/o regularización de tierras para adaptar el terreno a nuevas necesidades, 
en este caso concreto a la creación de una necrópolis intramuros ${ }^{27}$.

"4 marzo 1953. Se prosigue la excavación, y se descubre la sepultura $n^{\circ} 8$ que cierra a los pies con medio molino. El esqueleto está, por excepción, mirando al norte [debe entenderse en decúbito lateral izquierdo de acuerdo con el croquis, y no un enterramiento orientado al norte]. Nada de ajuar funerario (fotos). Se hallaba la sepultura sobre tierra removida, alterados los niveles, como lo demuestra el hallazgo de un cuello de anforita de tipo visigodo [dibujo] y fragmentos de cerámica de varias épocas. La cruza por debajo una pared y más abajo otra de adobes [...]. La superficie excavada es ésta: [croquis de la planta y la sección]. Después se siguió vaciando la alberca, encontrando junto al piso diez monedas, tan sumamente oxidadas que temo no podamos clasificarlas, lo que será una lástima, pues ellas nos darían la fecha del final de su uso. También han aparecido trozos de vidrio, barro, lucernas, [...]. 5 marzo [...] Al vaciar la balsa, se descubren en su piso, dos sepulturas, en la forma indicada en el croquis precedente". Según dicho croquis, ambas sepulturas -9 y 10 de la planta general-, paralelas y separadas 2'20 m, se orientaban E-O adaptadas a las paredes de la piscina preexistente, cuyo fondo rascan, y medían unos $45 \mathrm{~cm}$ de anchura (Fig. 2).

"7 marzo 1953 - 2 hombres. Continúo las excavaciones junto a las sepulturas abiertas sobre el pavimento romano, excavadas en 1952 [ $n^{\circ}$ 1 y $n^{\circ} 2$ en la planta general]. Al norte de ellas, encuentro otras dos sepulturas [ $n^{\circ} 11$ y $n^{\circ} 12$ ], con análogas características que las otras: Fosa abierta rompiendo el trespol romano, y luego, con losas y piedras de varia clase construyeron unos muretes laterales; cubren estas sepulturas, losas escuadradas o simples piedras. [croquis]. La señalada $x(12)$, tenía las losas del oeste, sobre la cabeza y cuerpo, caídas en el lado norte. Tal vez por eso, las filtraciones de agua de riego hayan sido mayores y hayan contribuido a la descomposición del esqueleto que más que verlo, lo hemos adivinado, pues eran realmente polvo sus huesos. Cribada la tierra he encontrado dos pendientes de cobre [dibujo], uno de ellos con adorno de vidrio; cuentas de collar, de vidrio,

27. En cualquier caso, la mayor parte de las referencias sobre los niveles más antiguos que se desprenden de los diarios de excavación de Alejandro Ramos se omiten aquí por no vincularse, ni temàtica ni cronológicamente, con el tema propuesto, y, por tanto, la cita directa de la información recogida en los mismos no es, ni mucho menos, exhaustiva.

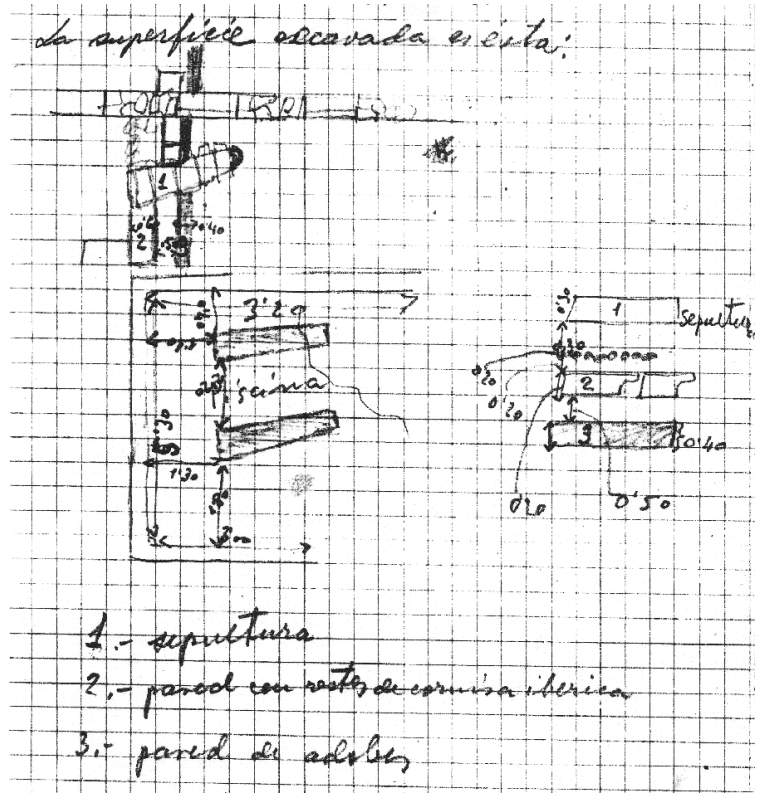

Figura 2: Croquis de A. Ramos de la planta de las tumbas 8,9 y 10 , y la sección de la primera, de la necrópolis del Borrocat.

hueso y ágata, y entre ellos, huesos de pescado perforados, un anillo de cobre, y otro de cinta con sello [dibujo]. Continúo hasta el nivel $\mathrm{E}$, en el que aparece otra pared [...], y bajo de las sepulturas cerámica pintada con figuras animales y humanas, destacando estos fragmentos [...] [dibujos], lucerna, dos monedas de cobre (ases de Jano) [dibujos]."

"9 marzo 1953, 1 hombre Bonifacio. Procedemos a descubrir la sepultura xx (2), o mejor dicho, a vaciarla, puesto que fue descubierta en 1952. En ella encontramos un collar de cuentas de vidrio y una de ágata. En un dedo, seis anillos de cobre. En otro dedo, un anillo de hierro y otro de cobre. Y otro anillo en otro dedo. También dos pequeños bronces [...]."

"10 marzo 1953 - Bonifacio solo. Descubrimos tres sepulturas sin ajuar alguno en ninguna de las tres". Probablemente se refiere a excavar las ya descubiertas $n^{\circ} 1$ y $n^{\circ} 11$ de la planta general, y aquella sin numerar del 8 de mayo de 1952 , la primera que descubrió y que, como la $n^{\circ}$ 2 , podía no haber sido excavada hasta ahora, o bien la $n^{\circ} 13$, hallada en este momento de acuerdo a su numeración aunque nada más se dice al respecto.

El 7 abril "Se excava a poniente de las cuatro sepulturas, dos con ajuar. Sólo encontramos algun fragmento cerámico en nivel $E$ y una fusayola negra." El día 10 "Se descubre o encuentra, al norte de las sepulturas con ajuares, 
otra [dibujo], que indico en el croquis del día 8." Es la $n^{\circ} 14$ de la planta general. El día 11 "Se excava una zona al norte de la sepultura última, y junto a la habitación con restos de estucos. No se encuentra nada."

El 12 de abril excavó la "casita ibérica", una construcción ubicada al este de la tumba $n^{\circ} 14$ y al sur de la habitación con paredes estucadas, a un nivel inferior, hallando numerosos fragmentos de la conocida cerámica Elche-Archena, "todo ello en una casa con paredes de adobe, sobre un murete de piedra". El día 18 también halló numerosos fragmentos cerámicos en los "niveles $D$ y E", e incluye un croquis de la "casita ibérica" en que se mezclan muros pertenecientes a distintas épocas y direcciones: de adobes, estucados, etc. Cabe destacar la inclusión de un croquis de los distintos niveles excavados en que $\mathrm{B}$ y $\mathrm{C}$ aparecen marcados por sendos pisos de argamasa, separados por unos $25 \mathrm{~cm}$, de 12 y 13 $\mathrm{cm}$ de grosor respectivamente, mientras que a $D$ corresponderían las paredes de adobes, relacionadas con un nivel de paso de arcilla verdosa y gravillas. El día 25 de abril finalmente excava la tumba 14, cubierta por tres losas muy grandes o bien sillares: "esqueleto completo y bien conservado. Sin ajuar".

El 20 de mayo "Se rompe el piso de la habitación romana que conservaba en la pared estucos pintados. Bajo de ella se descubren restos de piso, con ladrillos, en la forma que indica el croquis precedente y fotografías. ¿Estará esta construcción relacionada con la necrópolis?". Comienza así Alejandro Ramos la excavación del nivel inferior del edificio que, en las memorias publicadas, será interpretado como monumento funerario, y adjunta un croquis de las primeras fases de excavación así como otro posterior en que se muestra ya excavado todo el conjunto (Fig. 3).

El 21 de mayo "se rompe el piso de la habitación romana al oeste de la anterior. Bajo de él, y sobre piso de gravillas, encontramos dos botellas pintadas, sin asas, o sea, a falta de ellas por estar rotas, una lucerna, cucharilla de hueso y asa o cogedor de bronce [dibujos]". El día 25 "se excava el compartimento $B$ del croquis precedente. No encontramos nada debido a que dicho lugar había sido ya excavado. En la cata, se rompió el muro oeste; allí debieron encontrar una sepultura cuyo esqueleto fue luego enterrado allí, amontonando los huesos". Cabe preguntarse aquí si nos hallamos ante excavaciones antiguas o bien ante unas mucho más antiguas frecuentaciones y saqueos de la necrópolis cuando algunas de las tumbas aún debían ser visibles, a lo largo de

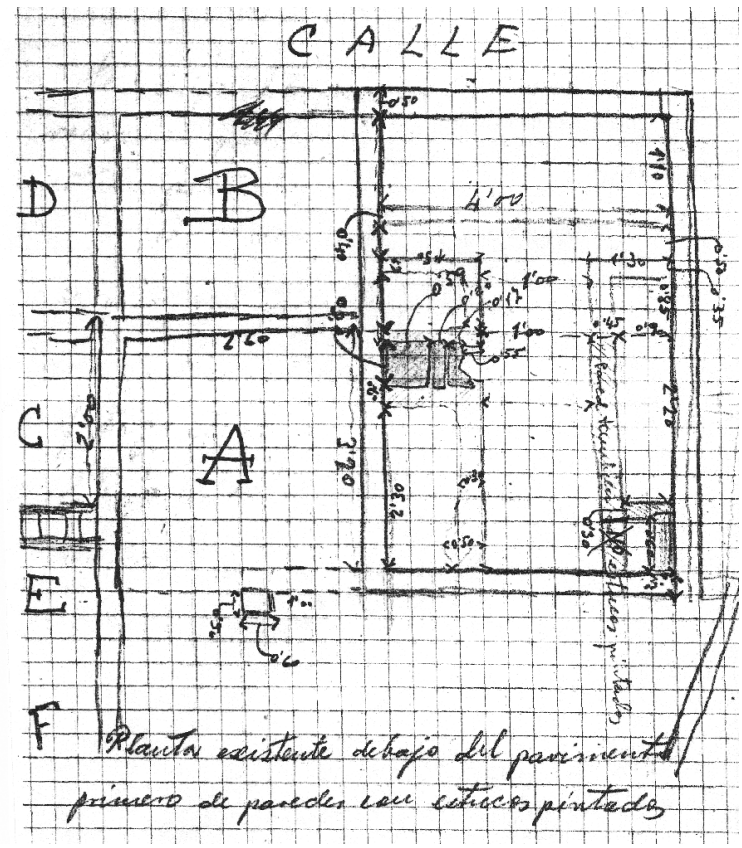

Figura 3: Croquis de A. Ramos del posible mausoleo del Borrocat excavado en 1953-1954.

los muchos siglos que median entre el abandono urbano de llici y su aprovechamiento agrícola.

Las excavaciones de 1953 acabaron el 30 de mayo, cuando "en lugar $D$, se encuentran los niveles alterados, con rotura de las paredes, indicio de haberse practicado allí alguna cata. Se encuentran algunos fragmentos de cerámica de toda clase y entre ella, un fragmento griego y una ampollita sin cuello ni pie [dibujos].

El 4 de enero de 1954 Alejandro Ramos continuó las excavaciones en la calle, al norte de la habitación estucada, encontrando los días siguientes diversas paredes de adobe "sobre el piso firme", que parecen marcar una pervivencia de la calle desde época ibérica pero ligeramente desplazada en época romana, quizá como consecuencia de la reorganización urbana que acompañó a la fundación de la colonia y la centuriación de su territorio. En cualquier caso, el día 14, "en el lado 0 . de la calle, al iniciar una nueva zona de excavación, continuación de la anterior, encontramos dos grupos de losas, tal vez sepulturas, cuya posición, así como los niveles allí existentes reproducimos en la página siguiente [croquis]". El nivel A del croquis corresponde a las tumbas -números 17 y 18 en estos croquis, pero 16 y 17 en la planta general que no muestra la $n^{\circ} 16-$, cuyas losas de cierre oriental -lo único visible pues la excavación avanzaba al oeste a partir del talud-testigo originado por la antigua excavación de la calle, y no desde la 


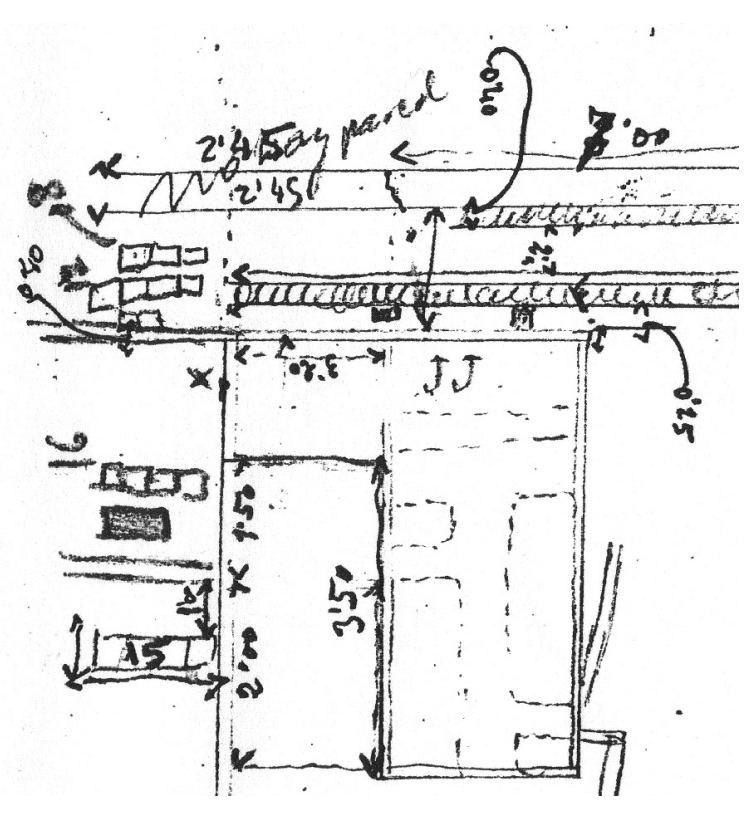

Figura 4: Croquis de A. Ramos de las tumbas 15, 16, 17 y 18 de la necrópolis del Borrocat, el posible mausoleo y la calle septentrional.

superficie del terreno- lo cortan para casi llegar a unas gravillas que, a $18 \mathrm{~cm}$, delimitan un nivel $B$, separado a su vez por $30 \mathrm{~cm}$ de un nivel $C$ marcado por un piso de cantos rodados de 15 cm de grosor.

Con la ayuda de diversos croquis, el diario continúa explicando que el 20 de enero se limpió la calle y se delimitaron los distintos niveles, y que "se acaba de excavar al N. de la alberca con dos sepulturas" los niveles inferiores a la tumba $n^{\circ} 8$. El día 21 "se continúa la excavación al $\mathrm{O}$. de la calle, profundizando hasta descubrir las sepulturas allí encontradas. En este nivel, B, apareció parte de una llave de hierro, un tapón de yeso, de ánfora, parte de una lucerna grande y algunos tiestos corrientes". El 22 de enero se excava la tumba $n^{\circ} 16$, paralela a $1 \mathrm{~m}$ al norte de la tumba $n^{\circ} 15$ aunque no aparezca en la planta general, con una longitud de 1'80 m y una cubierta compuesta por cuatro losas regularmente talladas, cuyas medidas eran, de este a oeste e indicando primero el lado que cubría la anchura de la tumba: $56 \times 34,70 \times 36,64 \times 56$ y $56 \times 48$ $\mathrm{cm}$. El mismo día se excavan las tumbas 17 y 18 , con longitudes de 1'50 m y 1'17 m, respectivamente, ambas enterramientos infantiles sin ajuar (Fig. 4). La mayor presentaba los huesos desechos mientras que de la menor pudo conservarse el cráneo en una caja de cartón. El día 23 "se prosigue la excavación bajo de las sepulturas" 17 y 18, encontrando diversos restos cerámicos de variadas épocas (Fig. 5).

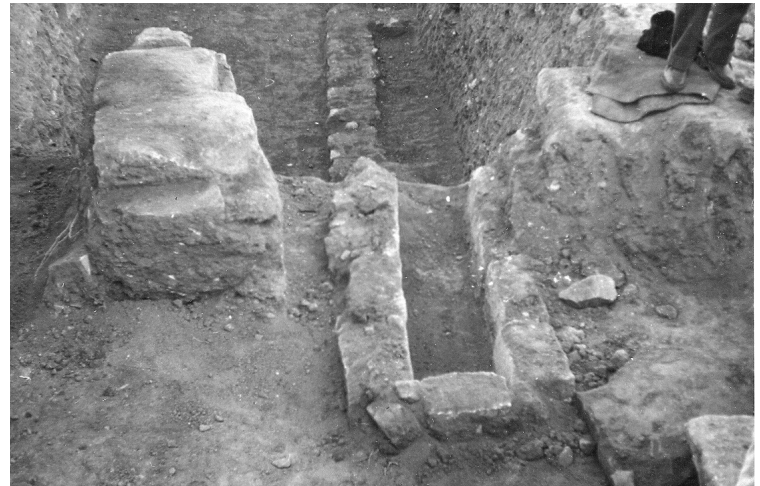

Figura 5: Tumbas 17 (excavada) y 18 de la necrópolis del Borrocat, infantiles, desde el Oeste.

El 26 de enero "en el lugar señalado $X$ en el croquis del dia 14 de enero, [la esquina nororiental del espacio en que la planta general representa el $2^{\circ}$ pozo manantial], y en el piso de este estrato $\mathrm{E}$, sobre el que estaban las tres ánforas, resto del empedrado del piso y una pequeña construcción con sillarejos" que delimita un espacio de $30 \times 28 \mathrm{~cm}$. Al día siguiente, "a 1'10 $\mathrm{m}$ [por debajo] de la loseta base de la ornacina [sic] (?) una vasija, con el borde roto, conteniendo los huesos de un niño (?)". A pesar de la falta de datos sobre profundidades y relaciones estratigráficas, este hallazgo se relaciona difícilmente con la necrópolis, y más bien parece algún tipo de ritual fundacional de un edificio anterior, quizá de época ibérica, pero ahí queda apuntado por la inmediatez a otras dos tumbas infantiles.

El 29 de enero tres operarios de Alejandro Ramos llegan al suelo virgen de la zona excavada los últimos días y descubren un círculo de tierra removida que resultó ser el segundo pozo manantial. "En él, hasta dos metros de profundidad del piso virgen y cinco escasos del nivel actual del bancal, encontramos muchos fragmentos de estuco de pared y techo, con pinturas al fresco (?), algunos con flores muy bonitos" así como muchos otros objetos de cobre, hueso, mármol y cerámica variada, y una moneda de Treboniano Galo (251-254) muy cerca del fondo. Tras varios días explorando esa zona, en la parte nororiental del sector 6-F el 19 de febrero comienza la excavación de "unos hoyos a modo de silos primitivos, utilizados luego, en época romana, como vertederos", con "muchas escamas de pescado y otros restos de peces, conchas y otros animales" y, muy próximo a ellos, el 22 de marzo se empieza a excavar el tercer pozo manantial romano, que corta a uno anterior ibérico, más ancho y profundo, por lo que el romano refuerza con 


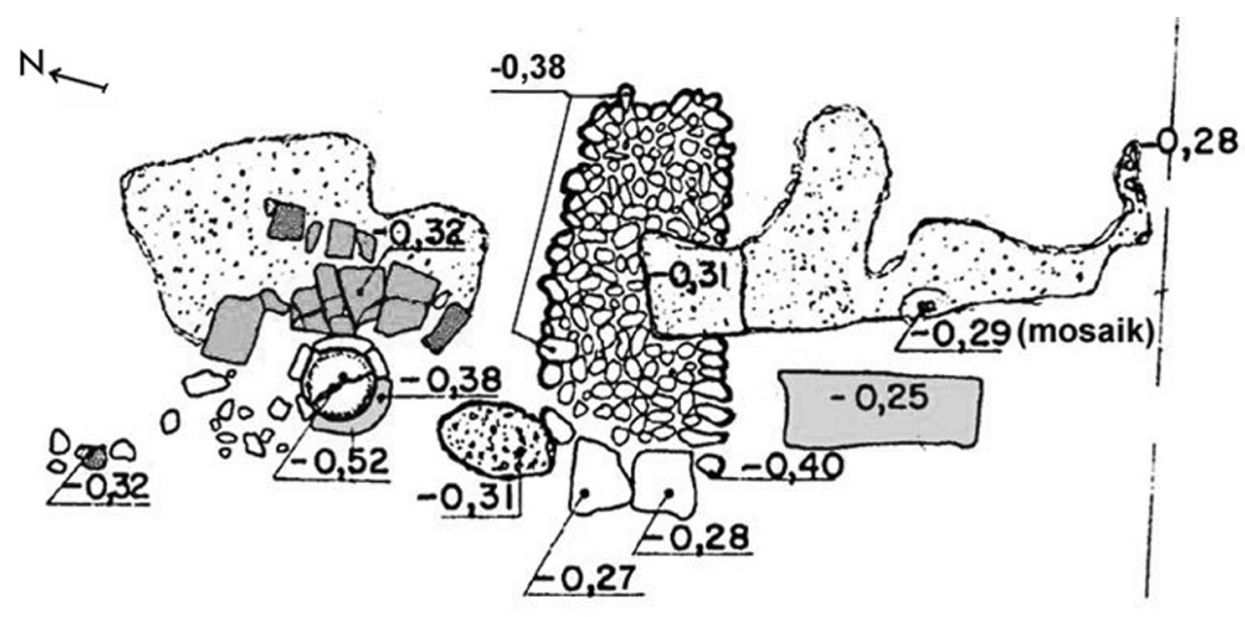

Figura 6: Ángulo S-O de la planta de la basílica tomada por Th. Hauschild y L. De Frutos en 1971, coloreada según el esquema: Amarillo = piedra/sillar; rojo = ladrillo; azul = mármol.

tegulae el lado sudeste de contacto con el relleno del anterior. En el relleno del pozo romano "cerámica romana tardía, como en los manantiales 1 y 2 [...] varios clavos de hierro, algunos de ellos con restos de la madera en que estaban clavados" y un par de monedas: de Gordiano III (238244) y Filipo el Árabe (244-249).

Tras una larga interrupción ${ }^{28}$, el 24 de septiembre se reanuda la excavación junto al caminal que va al Borrocat, y el día 27 "da la sensación de que el terreno ha sido removido ya que salen mezcladas las cerámicas", al tiempo que se descubre el último de los cuatro "pozos manantiales", separado apenas $3 \mathrm{~m}$ al oeste y en la misma habitación que el $n^{\circ} 3$ y el pozo ibérico, excavado los días siguientes.

El 1 de octubre, en el departamento S -la dependencia al norte de la calle y al oeste de la habitación con los pozos 3 y 4 de la planta general-, aparece "junto a la pared, y junto a una gran piedra, enfrente del molino, el esqueleto de

28. La excavación del pozo ibérico se interrumpe por las lluvias que la vuelven imposible y el 12 de abril se traslada al sudoeste de la basílica reexcavada en 1948, con una serie de croquis y dibujos de los materiales allí hallados, $y$ un esqueleto infantil en el nivel $F$ que Alejandro Ramos plantea como "sacrificio?", de nuevo a demasiada profundidad y muchos pavimentos de la superficie como para relacionarlo sin problemas con áreas de necrópolis cercanas, en este caso la ad sanctos próxima al ábside de la basílica. En septiembre se retoma la excavación del pozo ibérico, el cual presenta huecos en su relleno de hasta 3'90 m, síntoma de una rápida colmatación y posterior asentamiento desigual del material de relleno, bastante homogéneo hasta llegar a los $36 \mathrm{~m}$ de profundidad en que aflora el agua y deben parar los trabajos. un niño pequeño". Este esqueleto, orientado surnorte y adaptado a la esquina suroriental de ese departamento $\mathrm{S}$, aparecía flanqueado por la propia pared del este a su derecha y por una gran piedra a su izquierda, mientras que la cabecera la conformaba la pared sur. Posterior a la habitación y probablemente contemporáneo al resto de enterramientos de la zona, supone el tercer enterramiento infantil aparecido en este sector norte de la necrópolis, relativamente cerca de las tumbas 17 y 18. Los días 8 y 9 de octubre se continuó la excavación desde ese punto hacia el este, hacia la casa de la loma, donde daba "la sensación de que aquí fué donde hizo una de sus zanjas Albertini, pues en los croquis que publicó señala una de sus catas aproximadamente en este lugar. Salen tiestos romanos junto con ibéricos y trozos de piso y estucos, todo mezclado". Ese último día "asentado sobre la tierra virgen, o sea, en el nivel inferior, encontramos una basa de columna octogonal, de grandes dimensiones [dibujo]", quizás propia de los momentos fundacionales de la colonia, pero las lluvias obligaron nuevamente a cambiar de escenario y volver a la basílica para hallar nuevos restos de canceles o celosías.

De este modo, las últimas actuaciones constatadas en el sector 6-F las tenemos el 16 de diciembre, cuando Alejandro Ramos vuelve a sondear "un trozo más de la muralla que hay al E de la Alcudia, junto a la Veleta", aunque el día 23 se ve nuevamente obligado a excavar la zona al suroeste de la basílica, y también el 7 de enero de 1955, cuando tres hombres "se dedican a descubrir y limpiar el trozo de muralla al E, junto al algarrobo de la Veleta. Los niveles alterados 

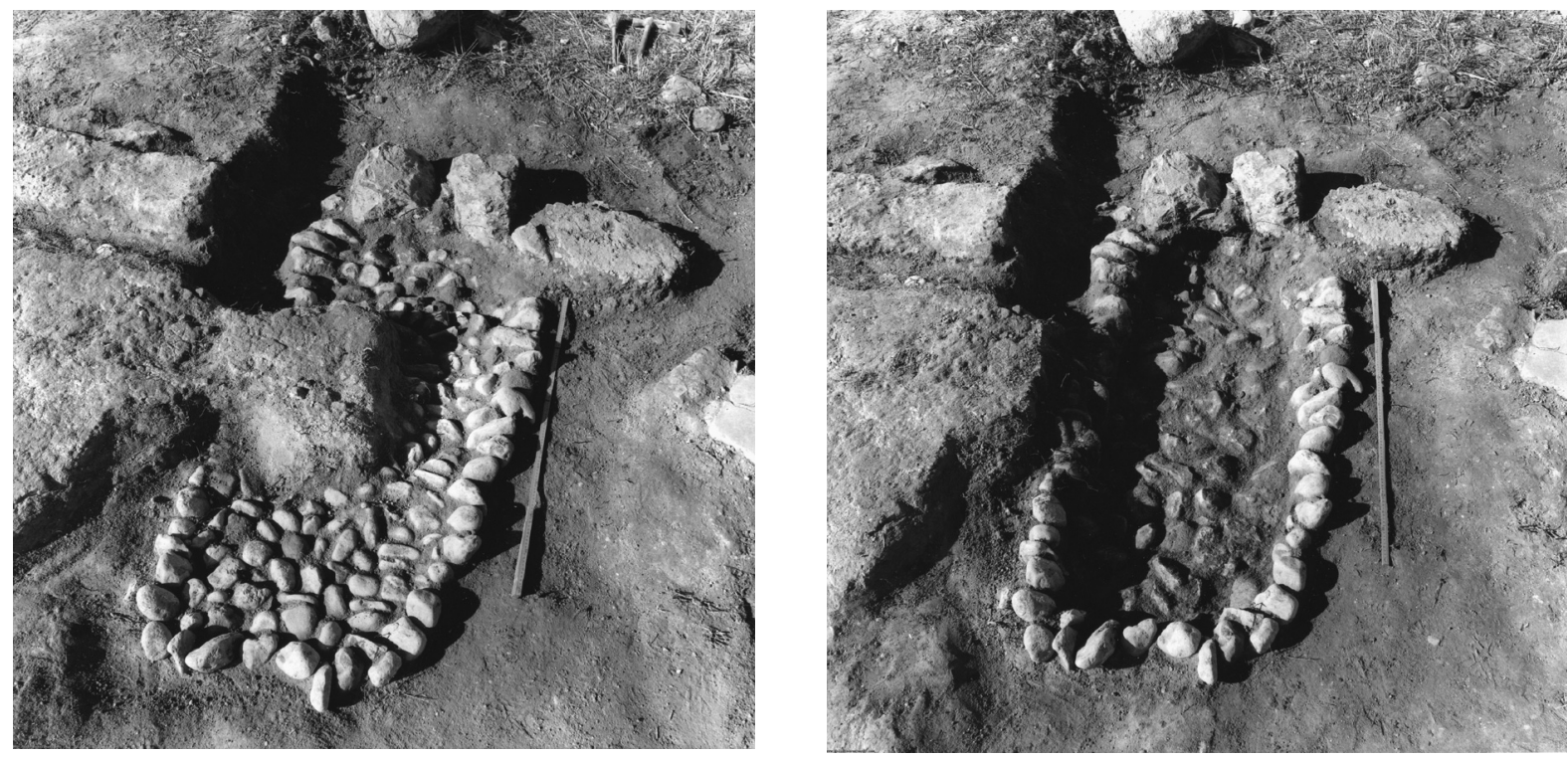

Figura 7 a y b: Fosa sellada por la argamasa que acogió al mosaico (Fotos Th. Hauschild).

por excavación en época romana, probablemente. Entre las cerámicas de época visigoda, a dos metros de profundidad se encontró una figurita de vidrio que parece la virgen con el niño".

Y así obtenemos una visión que, si bien más pobre de lo que querríamos, enriquece mucho -número y disposición de las sepulturas, relación de éstas con algún elemento de cultura material, algunos croquis planimétricos de plantas y secciones, etc.- la lacónica versión que se desprendía de las memorias de excavación.

Por otra parte, en 1971 un equipo del Instituto Arqueológico Alemán, compuesto por los arqueólogos Helmut Schlunk y Theodor Hauschild y el dibujante Laureano de Frutos, visitó dos días l'Alcúdia con el objeto de precisar cierta información sobre la planta de la basílica. Tras comprobar que el mosaico yacía -tal y como se había arrancado del suelo en 1949- apilado contra las paredes del almacén del Museo y sin posibilidad de estudiarlo en su conjunto, levantaron sobre los restos visibles del edificio basilical una planta con cotas en la que se reflejó alguna tesela aún in situ así como la argamasa que sirvió de cama al mosaico y varias estructuras aún visibles: restos de paredes, del ábside y las bases de los espigones en que se aguantaban los canceles (Schlunk y Hauschild, 1978, 9, lám. 3). Ésta es la única planta con cotas con que cuenta la investigación actual (Fig. 6) y la única también anterior a la recreación que se hizo del edificio a finales de los años ochenta, recreciendo unos muros y obviando otros en beneficio de una imagen más acorde con la que planteaba su excavador Ra- fael Ramos, y que ha sido publicada después (Ramos Molina, 1997, Fig. 23).

El descubrimiento en el AFA de cuatro fotografías de la basílica de Alejandro Ramos, marcadas con la fecha 1971, en las que se veía una fosa de tendencia rectangular orientada de este a oeste en el ángulo sudoeste del edificio -y nunca comentada en sus publicaciones-, me hizo volver a la planta de la basílica publicada por Helmut Schlunk y Theodor Hauschild en 1978 y comprobar que sí marcaban aquella fosa que, en un primer momento, permitió sugerir un recorte del pavimento de mosaico (Lorenzo, 2005, 145146). Pero aquellas fotografías de Alejandro Ramos coincidían en el tiempo con la expedición del Instituto Arqueológico Alemán, y en las propias tomadas por Theodor Hauschild se aprecia claramente cómo la argamasa que sirve de cama al mosaico sella la parte superior de la fosa (Fig. 7 a y b), tal y como también se observa en la planta entonces tomada, siendo por tanto claramente anterior al mosaico. Es en las fotografías de Alejandro Ramos que la fosa ya aparece excavada (Fig. 8), pero sin que se sepa qué había en su interior ni nada mencione en la memoria de aquella campaña (Ramos y Ramos, 1976), ni en su diario de excavación de 1971.

Finalmente, en 2003 Eduardo López y Sergio Llorens dirigieron una intervención de urgencia en las parcelas Camí del Borrocat I y II, colindantes con el yacimiento de l'Alcúdia a levante, y un primer informe apareció en el CD Actuaciones Arqueológicas en la Provincia de Alicante correspondiente a ese año (Tendero et alii, 2004). La 


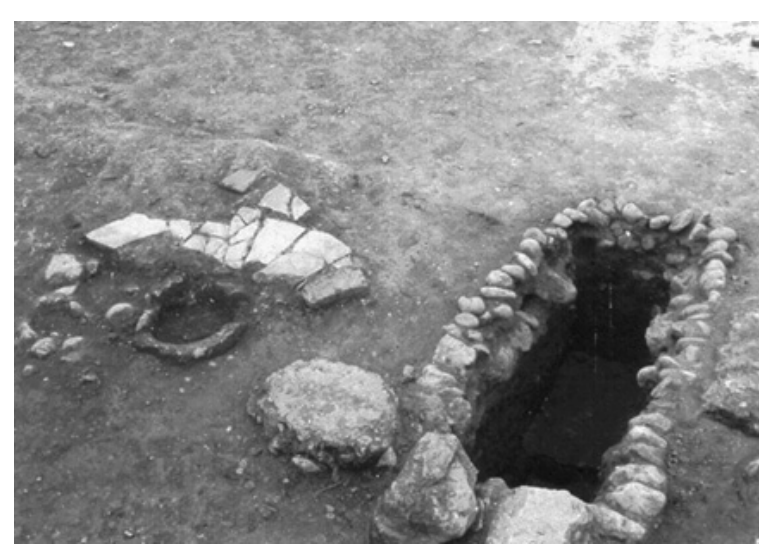

Figura 8: Fosa anterior ya excavada en 1971 (Foto A. Ramos).

intervención consistió en excavar mecánicamente una serie de zanjas paralelas para documentar la existencia y entidad de los posibles restos arqueológicos y evaluar el impacto de las obras a efectuar en ambas parcelas. Del informe publicado y de toda la información generada por esa intervención de urgencia nos interesa la existencia de una inhumación segura, y otras dos que los excavadores apuntan como probables, situada la primera a escasos metros de la zona en que Alejandro Ramos descubrió la gran necròpolis del sector 6-F, y de la que sin duda debió formar parte.

\section{LAS NECRÓPOLIS ILICITANAS EN LA AN- TIGÜEDAD TARDÍA}

A partir de toda esta información defenderé en las páginas siguientes la existencia de cinco necrópolis para llici en la Antigüedad tardía (Fig. 9). Dos de ellas se ubicaban intramuros y debían modificar la trama urbana imperial: una primera y principal en la parte centro-oriental de la loma, con un gran número de enterramientos y quizás organizada en torno a un mausoleo, y otra ubicada en un sector aparentemente marginal de la ciudad, organizada en torno al ábside de la basílica paleocristiana. Por otra parte, en el área periurbana ${ }^{29}$ de llici se localizan tres necrópolis: Una de larga tradición romana inmediata al norte del yacimiento, con un

29. De acuerdo con el criterio de Ricardo González Villaescusa $(2001,127)$, las necrópolis extramuros pueden dividirse entre las ubicadas en un área periurbana, la localización por excelencia de las necrópolis urbanas entre 1 y $2 \mathrm{~km}$ de distancia al centro, o bien en un área suburbana entre los 2 ' 5 y los $5 \mathrm{~km}$ que engloba una serie de necrópolis que no deben confundirse con las propiamente urbanas aunque sí se desarrollan bajo el influjo de la ciudad. número importante de enterramientos y variada tipología de tumbas, y posiblemente vinculada a la principal via de comunicación del territorium ilicitano, la via Augusta. Otra a $1500 \mathrm{~m}$ al sur de l'Alcúdia probablemente también vinculada a la via de entrada a la ciudad. Y aún una tercera que, ubicada más al norte que la primera, a unos 1000 $\mathrm{m}$ de la loma, puede que perdurase en época islámica y que, peor conocida, dejaremos para el final. Varias concentraciones menores y alguna sepultura aislada repartidas a lo largo de los principales ejes de la centuriatio completan el paisaje funerario tardío de $\mathrm{Ilic}^{30}$.

\subsection{Necrópolis del Torrero $\left(38^{\circ} 14^{\prime} 30 » \mathrm{~N}, 0^{\circ} 41^{\prime} 47 » \mathrm{~W}\right)$}

En un sentido norte-sur analicemos primero la necrópolis periurbana documentada a mediados del siglo XIX por Aureliano Ibarra, quien suponía que "[...] por aquel sitio, se dilataba una

30. "In the case of the villa sites in the (centuriated) Campo de Elche, the location of sites given in the two principal sources (Ramos Fernandez 1975; 1976) are often conflicting and illustrate the need for modern, accurate, survey in this area. Indeed, though a few villa sites were located from these sources, I was forced to abandon hope of finding and mapping sites in the area by this process" (Reynolds, 1993, 45). Para solucionar este problema se facilitan aqui unas coordenadas básicas de latitud y longitud, obtenidas a partir del programa Google Earth para cada una de las localizaciones, y poder simplificar así algunas dobles citas anteriores sobre la hoja 893 de la Dirección General del Instituto Geográfico y Catastral, de más compleja consulta, aunque muy interesante en su edición de 1949 por la eliminación de la red viaria contemporánea. La referencia facilitada tan sólo es aproximada por la imposibilidad de ubicar con precisión alguna necrópolis excavada hace 150 años como la del Torrero, o la falta de datos como en el caso de la del Campo de Experimentación Agrícola.

Por otra parte tenemos los hallazgos aislados referenciados por Pere Ibarra en función de la propiedad en que aparecían $-\mathrm{y}$, luego, citados por Alejandro Ramos (1953)-. Éstas han podido ser localizados sobre un Bosquejo Planimétrico del término municipal de Elche en que se indican los nombres de las casas o haciendas rurales, confeccionado por el Instituto Geográfico y Estadístico a una escala 1:25000, sin fecha (aunque se marca que la copia costaba 10 pts), y conservado en el AHME sin referencia pues aún está pendiente de restaurar y catalogar. Debo agradecer la posibilidad de consultarlo y fotografiarlo a su director el Dr. Rafael Navarro Mallebrera. Las siguientes coordenadas hacen, por tanto, referencia a la casa y no tanto a los bancales y tierras en que aparecían las sepulturas: $\mathrm{H}^{\mathrm{a}}$ de Torregrossa $\left(38^{\circ} 15^{\prime} 00^{\prime \prime} \mathrm{N}, 0^{\circ} 42^{\prime}\right.$ 39" W); El Pilar (38 15' 23" N, 0 41' 13" W); H $\mathrm{H}^{\mathrm{a}}$ de Porter

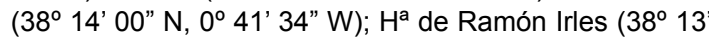
$\left.57^{\prime \prime} \mathrm{N}, 0^{\circ} 41^{\prime} 40^{\prime \prime} \mathrm{W}\right)$; $\mathrm{H}^{\mathrm{a}}$ de Espinosa (38 $13^{\circ} 14^{\prime \prime} \mathrm{N}, 0^{\circ} 40^{\prime}$ $37^{\prime \prime} \mathrm{W}$ ); y Ha de Guilló (38 12' 05” N, 0 40’ 36” W). 


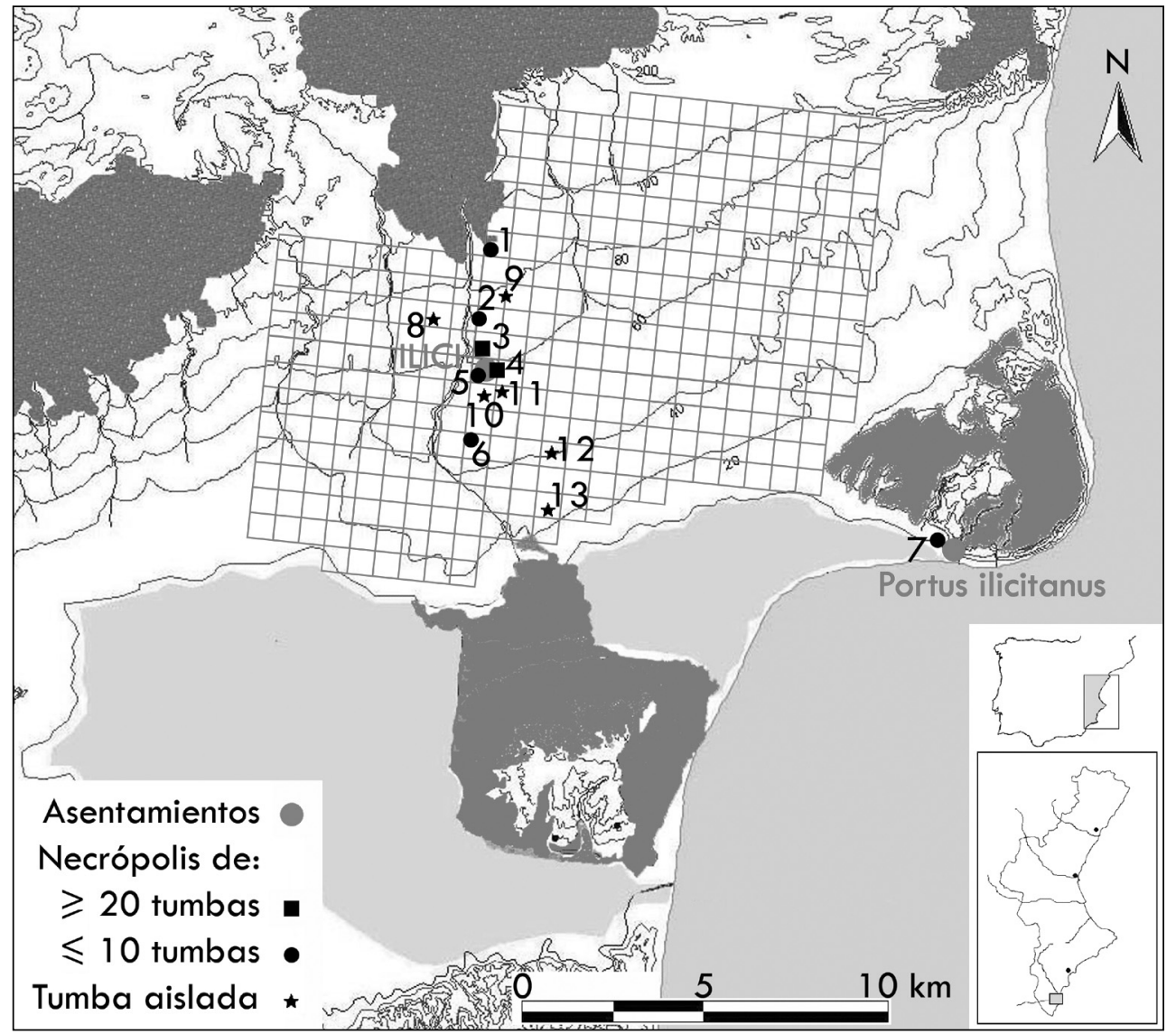

Figura 9: Hallazgos y yacimientos localizados en el mapa. 1: Sepulturas en c/Velarde. 2: Necrópolis del Campo de Experimentación Agrícola. 3: Necrópolis del Torrero. 4: Necrópolis del Borrocat. 5: Necrópolis de la basílica. 6: Necrópolis del Tio Peix. 7: Sepulturas en Santa Pola. 8: Tumba en $\mathrm{H}^{\mathrm{a}}$ Torregrossa. 9: Tumba en El Pilar. 10: Tumba en $\mathrm{H}^{\mathrm{a}}$ Porter. 11: Tumba en $\mathrm{H}^{\mathrm{a}}$ R. Irles. 12: Tumba en $\mathrm{H}^{\mathrm{a}}$ Espinosa. 13: Tumba en $\mathrm{H}^{\mathrm{a}}$ Guilló.

de las principales vías de la ciudad, por cuanto por aquella parte se establecieron los sepulcros" (Ibarra, 1879, 167). Efectivamente, pese a la parquedad en la descripción -"inmediatamente que descendemos de la Alcudia, hácia el norte de ésta" (Ibarra, 1879, 167)-, en parte precisada por las Efemérides 147 y 247 de Pere Ibarra (vid. supra), el área de necrópolis podría coincidir con la que fue principal via de entrada a la ciudad, como ya supuso Alejandro Ramos (1953, 329-330), aquella via Augusta que conformaba el cardo maximus de la centuriación ilicitana (Gozálvez, 1974, 102-103).

Esta necrópolis podría caracterizarse por una larga utilización pues su excavador indica que "contigüo donde aparecían los modestos enterramientos ya mencionados, [...] hallamos vasos ó urnas de tierra cocida, conteniendo cenizas y ánforas cortadas longitudinalmente, en el interior de las que se hallaban restos humanos" (Ibarra, 1879, 168). Dicha descripción ha permitido a Ricardo González Villaescusa (2001, 399) proponer la existencia de una necrópolis de incineración "probablemente altoimperial" en la que destacaría un hypogeum parecido a uno de Cartagena, pues así considera (González, 2001, 384-385) la cámara subterránea que, por la descripción, la planta y la sección, el propio excavador (Ibarra, 1879, 169-171 y Lám. XIII) ya interpretó, con reservas, como un monumento funerario (Fig. 10) -"cripta" para Alejandro Ramos (1953, 330) y Paul Reynolds (1993, figura 58)-, que fue posteriormente desmontado y vendidos los sillares que lo componían, lo que da idea de su entidad. El mantenimiento de una necrópolis en esta zona desde época imperial estaría, por otra parte, refrendado por la propia existencia de la principal vía de acceso, que condicionaría la pervivencia del enterramiento tal y como resulta común en las ciudades romanas.

La existencia de una fase imperial permite clasificar esta necrópolis dentro de las periurbanas y no intramuros puesto que, pese al desconocimiento actual sobre la extensión y delimitación de la llici romana -que teóricamente podría desbordar la extensión estricta de l'Alcúdia en 

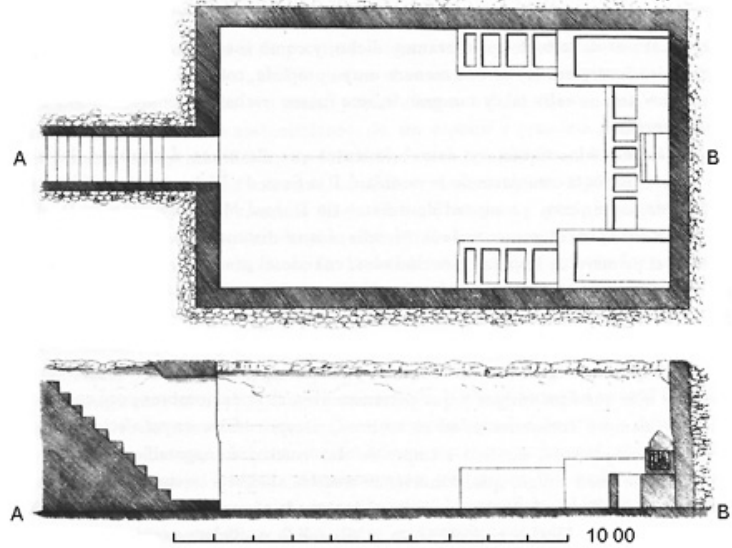

Figura 10: Hipogeo altoimperial de la necrópolis del Torrero, según dibujo de $\mathrm{A}$. Ibarra.

cualquier dirección-, nunca hubiera podido darse una necrópolis altoimperial en el interior de la ciudad, y sí en cambio en sus inmediaciones. De manera que, indirectamente, podemos limitar el perímetro norte de la ciudad romana al contorno aproximado de la loma en ese punto, recordemos que el más alto y quizás aprovechado como defensa y atalaya, si bien parece probable que la colonia desbordase ampliamente el pequeño altozano en el resto de puntos cardinales, como apuntan las muchas evidencias arqueológicas aparecidas en los últimos 150 años.

En una fase tardía de la necrópolis las inhumaciones parecen la norma, y podemos establecer diversos tipos de enterramiento según la descripción de su excavador:

Tipo 1. Tumbas rectangulares realizadas con sillares desbastados, con lajas de $2 \times 0,80$ $\mathrm{m}$ y $40 \mathrm{~cm}$ de grueso como laterales y otras dos colocadas en pie y cabecera que encajan en sendas ranuras de las laterales. Los cuerpos se depositan -desconocemos posición o ajuar- en cajas de madera, y la cubierta la conforman tres ladrillos de $90 \mathrm{~cm} 2$ y $8 \mathrm{~cm}$ de ancho cada uno, con digitaciones en forma de aspa en su superficie, y todo bajo una capa de cal y guijarros de unos $45 \mathrm{~cm}$.

Tipo 2. Tumbas de tendencia rectangular con paredes de mampostería. Como en el caso anterior, los cadáveres se depositan -desconocemos posición o ajuar- en cajas de madera, y la cubierta la conforman también tres ladrillos con digitaciones y la misma capa de cal y guijarros.

Tipo 3. Sarcófagos de tendencia rectangular realizados en un único bloque en el que se talla una cavidad destinada a alojar un cadáver del que también desconocemos posición o ajuar.
Una gran losa de piedra, que ocupa toda la extensión del sarcófago, forma la cubierta.

Como paralelos constructivos cercanos, y para los dos primeros tipos identificados, en l'Almoina de València se constatan unos infrecuentes "enterraments amb coberta de tègules planes en fosses recobertes de calç" (Blasco et alii, 1994, 91), datados a partir del siglo V. Por su parte, la capa de cal y guijarros puede relacionarse con las cubiertas de encachados de la necrópolis del Corralón en Los Belones (Cartagena), de los siglos IV-VII (Antolinos y Vicente, 2000), así como con algunas de las tumbas de la necrópolis del Camino del Monastil en Elda, de la segunda mitad del siglo $\mathrm{VI}$, pues "algunas de ellas presentan un sellado superior mediante pequeñas piedras trabadas con abundante cal" (Segura y Tordera, 2000, 264). También recuerda a la cubierta tumular de opus caementicium de algunas sepulturas de la necrópolis valenciana de la Boatella (Albiach y Soriano, 1996a), de los siglos III-V, y al tipo $F$ de la necrópolis occidental de Valentia (Rosselló y Ruiz, 1996), de los siglos III-IV. Exclusivamente para el tipo 2, las tumbas presentan un fuerte parecido con el tipo B de la necrópolis de San Antón en Cartagena ${ }^{31}$, de mediados del siglo IV al VI (Berrocal y Laiz, 1995), así como con el segundo tipo de sepulturas de la necrópolis del Camino del Monastil, de la segunda mitad del siglo VI (Segura y Tordera, 2000), que se orientan norte-sur -desconocemos la orientación de las excavadas por Aureliano Ibarra-, y, en menor medida, al grupo A de la necrópolis de La Molineta (Mazarrón), de los siglos V-VII (Amante y García, 1990; López y Amante, 1991).

Para el tipo 3 -toscos sarcófagos de piedra de tradición romana también presentes en otros lugares del yacimiento y relativamente comunes a partir de los siglos II-III cuando el mundo romano recupera la inhumación-, como paralelos más cercanos tenemos la desaparecida necrópolis de Las Torres, con cerca de 30 individuos y varios sarcófagos en l'Albufereta (Alicante) (Reynolds, 1993, 50-51), así como dos sarcófagos monolíticos "del período de la decadencia romana" que fueron hallados en El Monastil (Elda) en los años veinte, aunque actualmente están desaparecidos (Márquez y Poveda, 2000, 182).

31. "Fosas rectangulares revestidas en sus paredes por muretes de mampostería, con ladrillos, cantos rodados o piedras medianas trabados con mortero de cal. El fondo está compuesto por piedras medianas [...]. Su cubrición se realiza en horizontal, con ladrillos del tipo bipedalis o tégulas" (Berrocal y Laiz, 1995, 173). 
Complementando la información anterior, de acuerdo con la Efeméride 247 de Pere Ibarra, del 3 de junio de 1900, otros tres enterramientos, uno de ellos femenino, aparecieron "muy a la superficie" en el mismo terreno. Estos cuerpos... ¿estarían enterrados en una fosa simple o ataud de madera, o bien una estructura de mamposteria sencilla pasó desapercibida a los trabajadores que los encontraron? En el segundo supuesto no parece claro adscribirlos a ninguno de los tipos descritos por Aureliano Ibarra, puesto que nada se dice de cubierta de ladrillos o capa de argamasa, y los cuerpos aparecieron enteros -y por tanto ni saqueados ni desprovistos de cubierta- en el momento de su hallazgo. Creo que debemos considerar, pues, un cuarto tipo de enterramiento más sencillo - ¿y más tardío también?-que los anteriores.

Como otro ejemplo de la pérdida de información sufrida, Aureliano Ibarra $(1879,168)$ habla de algunos descubrimientos efectuados en la misma zona con anterioridad a sus propias excavaciones: "Unos labradores [...] encontraron en los vários [monumentos, es decir, tumbas] que descubrieron, monedas y otros efectos, y en particular, en uno, que debió ser digno de mayor estudio y conservación, no sólo hallaron aun restos del esqueleto, sino tambien una espada y otros objetos, los que, dado su estado y el poco cuidado que de ellos tuvieron, se destruyeron bien pronto. Pero lo más doloroso, es que, ni rastro pudimos hallar, de una piedra que cubría aquel sepulcro, y la cual, decían, contenía una inscripción, pues la hicieron mil añicos [...]". Por tanto, no sólo había tumbas con ajuares complejos, incluso con armas -o herramientas- metálicas, sino que también las había, una al menos, con lápidas grabadas con inscripciones -reaprovechadas $\mathrm{u}$ originales- como cubierta y muchos otros datos irremediablemente perdidos.

En cualquier caso, con la información disponible obtenemos para esta primera necrópolis, en su fase tardía, una cronología aproximada de finales del siglo III o principios del IV a finales del siglo $\mathrm{VI}$ que la incluye en la plena tradición romano-cristiana. Una necrópolis de larga tradición, probablemente vinculada a la principal entrada norte de la ciudad desde la via Augusta, y en un terreno que estaba "muy obstruido de la obra antigua y piedras" (Pere Ibarra, efeméride 247), lo que quizá indique la existencia de construcciones adyacentes a la necrópolis altoimperial que fueran amortizadas en época tardía, o tal vez una expansión urbana o un carácter monumental de algunas de las tumbas, aunque sin más datos que los ofrecidos por estos antiguos testimonios y apenas información sobre los cuerpos y los ajuares, la ordenación del espacio o la relación de la necrópolis con su entorno más inmediato, debemos movernos en el pantanoso terreno de la conjetura.

\subsection{Necrópolis del Tío Peix $\left(38^{\circ} 13^{\prime} 26 » N, 0^{\circ} 42^{\prime} 05 » W\right)$}

De la segunda necrópolis periurbana teníamos una notícia por Alejandro Ramos $(1953,347)$ pero ahora la conocemos gracias al testimonio original de Pere Ibarra, en sus Efemérides 1221 y 1294 referidas a los años 1916 y 1917, quien menciona un grupo indeterminado de sepulturas aparecidas al sur de l'Alcúdia en el bancal de una casa propiedad de Agustín Agulló "el Peix". Allí aparecieron cuatro sencillos sarcófagos cubiertos con lajas de piedra de $10 \mathrm{~cm}$ de grosor y compuestos cada uno por dos sillares labrados y ensamblados. Si bien los cuatro mostraban 20 $\mathrm{cm}$ de profundidad para alojar el cadáver, dos de ellos disponían de un hueco de $35 \times 170 \mathrm{~cm}$, y se cubrían con tres lajas, mientras que otros dos sarcófagos eran de menores dimensiones, probablemente enterramientos infantiles, con un hueco de $38 \mathrm{~cm}$ en la cabecera y $27 \mathrm{~cm}$ en los pies por sólo $122 \mathrm{~cm}$ de largo, y se cubrían con dos lajas, una de las cuales parece un elemento de prensa reutilizado. También cita "varias otras" sepulturas realizadas con lajas, el suelo, y diversas hiladas de losas, las paredes, y en conjunto se conservaban suficientes restos óseos para poder identificar una orientación unánime de todas las inhumaciones suroeste-nordeste, con la cabeza hacia "la Cartagena".

Asociados al grupo de sarcófagos y otras sepulturas, destaca la aparición de unos fragmentos de piedra labrada "del mismo estilo que cierta ventana calada que se halló en la excavación de la Alcudia por Albertini. Son una columnita a modo de parteluz y el arranque de los arquitos y un trozo con ambas superficies labradas diseñando parte de unas alas o pliegue de ropaje" que nos remiten inexorablemente a los famosos canceles o celosías de la basílica ${ }^{32}$. Un

32. E incluso, por la comparación de esta descripción de Pere Ibarra con las fotografías publicadas sobre los canceles de la basílica, cabe preguntarse si los fragmentos hallados en 1916 no serían "traspapelados" cuando la reorganización póstuma del material de Pere Ibarra, y actualmente se incluyan erróneamente en las propuestas de reconstrucción de los fragmentos realmente identificados en la basílica por Eugène Albertini en 1905 (Albertini, 1906 y 1907) y por Alejandro Ramos a mediados del siglo XX. 


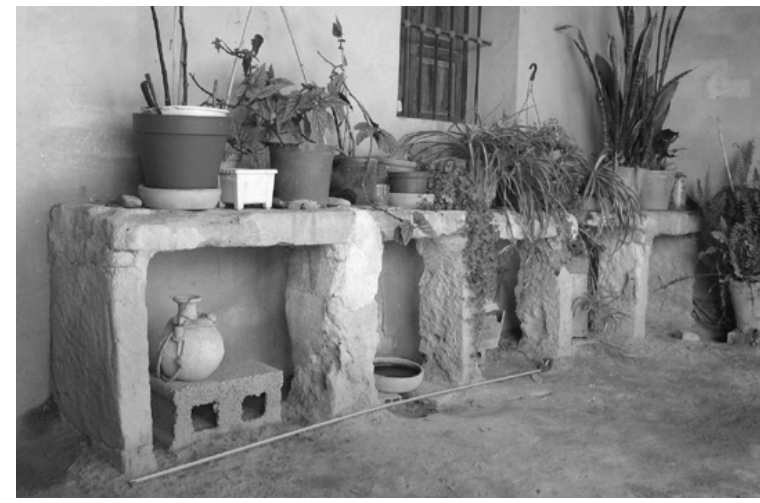

Figura 11: Losas de las cubiertas de la necrópolis del Tio Peix reutilizadas como banco. (El flexómetro marca $2 \mathrm{~m}$ ).

tercer fragmento de un pequeño friso con estrías triangulares, hallado entre el "enorme montón de piedras sueltas y tejas rotas", así como "muchos trozos de cantería y no pocos tiestos de tejas [...] curvadas" aparecidos el año siguiente junto a otro sarcófago en el mismo lugar, refuerza la hipótesis de una cierta monumentalización de este grupo de sepulturas que, desaparecido entonces por la alteración del terreno con fines agrícolas, quizá podría relacionarse con la continuación del camino principal que partía de llici hacia el sur, con cierta probabilidad la propia via Augusta.

En el mes de agosto de 2007 he localizado la casa "de Agustín Agulló" a que hace referencia Pere Ibarra en la partida rural de Daimés, con la grata sorpresa de descubrir, al lado de la puerta principal, un pequeño banco construido con algunas de las losas y otros materiales edilicios descubiertos en 1916-1917, allí empleados tal y como testimonian sus últimos habitantes ${ }^{33}$, quienes pudieron precisar la aparición de los restos en un bancal a poniente de la casa y su reutilización actual a mediados de la década de 1920 (Fig. 11). Las medidas aproximadas de las cinco

33. La casa llamada de Diego Sempere pasó a poder de Agustín Agulló Blasco, conocido como "el Tio Agustino", "el Peix" o "el Tio Peix", como herencia por su matrimonio con Teresa Sempere, hija del anterior propietario, y, posteriormente al descubrimento de las tumbas, los padres de la actual ocupante fueron allá a vivir y hacerse cargo de las tierras. Desde aquí mi mayor agradecimiento a los señores Magdalena García Vicente y su hijo Vicente Mollà García, los últimos habitantes de una hermosa construcción tradicional del Camp d'Elx que quizá sea la última en mantener un suelo de tierra apisonada tanto en la porchada como en el interior. Su sorpresa ante la antigüedad de las piedras que conformaban el banco decorado con plantas que llevaban viendo allí toda la vida sólo fue superada por mi alegría al descubrirlas y la posibilidad de fotografiarlas y medirlas. losas horizontales, de izquierda a derecha según la fotografía, son $86 \times 48 \times 10 ; 65 \times 46 \times 10 ; 67 \times$ $48 \times 10 ; 81$ x $48 \times 10$; y $72 \times 53 \times 10$. Las medidas aproximadas de las losas (primera y última) y bloques verticales (resto), colocados como columnas sustentantes de las anteriores, son, de nuevo de izquierda a derecha: $52 \times 46 \times 10 ; 60$ x $30 \times 20 ; 60 \times 24 \times 13 ; 59 \times 27 \times 12 ; 58 \times 2812$; y $57 \times 50 \times 7$.

Por lo que respecta a su orientación nortesur, con la cabeza a Cartagena, cabe recordar que tanto las tres construcciones funerarias como las ocho tumbas en fosa, de unos dos metros de longitud y cubiertas de tegulae planas o a doble vertiente, de la necrópolis de Orriols (Valencia) se orientaban norte-sur de acuerdo a su ubicación inmediata y paralela a una bifurcación de la via Augusta cercana ya a Valentia, quedando en primer plano para el viajero los mausoleos y en segundo término las tumbas en fosa (Albiach y Soriano, 1996b). Para el conjunto se propone una cronología general de principios del siglo III hasta el IV, y sólo en los momentos finales, que coinciden con la construcción del mausoleo principal, cambia la orientación de los enterramientos de dicha construcción -sepulcros de plomo separados por muretes y cubiertos por losas- para encararse al este. De manera análoga, para la necrópolis del Tio Peix, aunque desconozcamos la distribución espacial de sus distintos enterramientos, podríamos explicar la orientación norte-sur como la adaptación a la escenografía de una via romana preexistente. En cualquier caso la cronología sigue siendo un problema puesto que si se trata de tumbas de un momento anterior al siglo IV en que parece generalizarse la orientación este-oeste, que será la canónica del cristianismo incipiente, no parece claro relacionarlas con los restos ornamentales que remiten a la decoración de la basílica de Ilici en el siglo VII de dominio visigodo.

Si relacionamos la presencia de este conjunto de sepulturas con la centuriación ilicitana, en el sentido de localizar el cardo máximo que tradicionalmente se asocia a la propia via $A u$ gusta a su paso por la colonia -las dos opciones más lógicas son los ejes norte-sur que flanquean la antigua llici, la continuación de la calle Filet de Fora y carretera a Dolores al oeste y el camino del Borrocat al este-, la ubicación de las sepulturas a poniente de los $38^{\circ} 13^{\prime} 26$ » $\mathrm{N}$ y $0^{\circ}$ 42' 01» W, coordenadas de la casa de Agustín Agulló, nos acerca más al eje marcado por Filet de Fora e inicio de la carretera a Dolores. Y en cualquier caso las sepulturas a poniente de la casa parecen relacionarse por distancia con el 

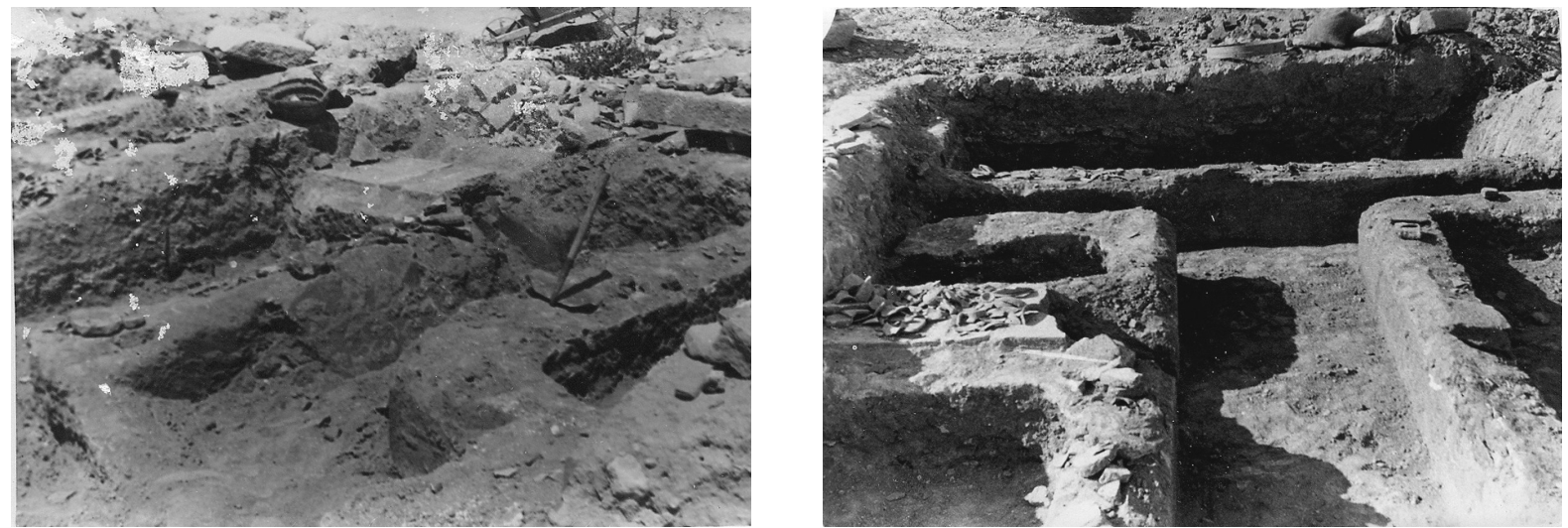

Figura 12 a y b: Fases de la excavación del posible mausoleo (Foto A. Ramos).

tercer decumano al sur de l'Alcúdia, quizás expuestas a la mirada de los viajeros cerca de la confluencia entre éste y el cardo máximo. Pero sin más precisiones sobre la ubicación exacta de la necrópolis, ni la organización espacial de las tumbas, de momento sólo puede apuntarse que tal vez la via Augusta no discurría al este de Ilici, por el actual camino del Borrocat, como parecería más lógico por la cercanía a un vial directo al Portus llicitanus, sino a poniente de la colonia al menos hasta un par de centurias más al sur, de acuerdo con la información aportada por esta desaparecida necrópolis.

\subsection{Necrópolis del Borrocat, en l'Alcúdia $\left(38^{\circ} 14^{\prime} 22 » \mathrm{~N}, 0^{\circ} 41^{\prime} 38\right.$ » $\left.\mathrm{W}\right)$}

Vistas ya las dos necrópolis periurbanas más cercanas a la loma entremos en la llici tardía, sede episcopal los siglos VI-VIII, para examinar las dos únicas necrópolis intramuros conocidas hasta el momento. Primero la ubicada "en las tierras sitas al sur del caminal que conduce al camino del Borrocat y al linde de la finca" (Ramos, 1956, 112 ), es decir, el sector 6-F del yacimiento en la terminología acuñada por Alejandro Ramos.

"En una zona próxima a lo que sería el centro neurálgico de la ciudad, lo que refuerza su carácter tardío y probablemente cristiano" (González, 2001, 401), a esta necrópolis pueden adscribirse hasta 30 inhumaciones seguras, de acuerdo con las memorias y diarios de excavación de Alejandro Ramos, algunas Efemérides de Pere Ibarra y dos excavaciones de los años 2002 y 2003, si bien es cierto que podemos suponer muchas más en el contexto del avance progresivo de las áreas funerarias en los suburbios y el interior de las ciudades a lo largo de la Antigüedad tardía -un fenómeno vinculado a la expansión del culto a los mártires cristianos y sus reliquias en diferentes basílicas suburbiales e intramuros (Godoy, 2005), aunque al estado actual de la investigación en llici tan sólo podemos precisar el carácter cristiano del conjunto de la necrópolis ad sanctos de la basílica-. En cualquier caso, no hay espacio ahora para tratar de las transformaciones urbanas de la llici tardoantigua y la aparición de las necrópolis intramuros, apuntando tan sólo la evidencia de una amortización concienzuda de antiguos lugares de hábitat en el sector oriental de la loma que ocupará la necrópolis del Borrocat ${ }^{34}$, así como de la colmatación de antiguos pozos a finales del siglo III ${ }^{35}$ y el acarreo de materiales para regularizar la nueva superficie funeraria en un momento aún indeterminado.

En esta necrópolis el primer elemento a remarcar es la existencia de una construcción cuya "obra es de un cemento bien enlucido en las paredes y el piso", con cuatro espacios principales a manera de receptáculos cuadrangulares comunicados por un pasillo en forma de L, y el posible aprovechamiento de los intersticios resultantes mediante una cubierta con ladrillos para la cual sólo contamos con un testimonio (Fig. 12 a y b). Alejandro Ramos $(1962,91)$ lo consideró un monumento funerario, mientras que Ricardo González Villaescusa (2001, 401-402) lo identi-

34. "The rather patchy knowledge of the archaeology of the town does tell us that a cemetery was built in the late 3rd or $4^{\text {th }}$ centuries within the town walls (Site 92.I) in an area of houses and street abandoned by the mid $3^{\text {rd }}$ century $A D "$ (Reynolds, 1993, 9). (La cursiva es mía).

35. Inerpretado tradicionalmente como testimonio de la destrucción de la ciudad por los francos en el siglo III (Ramos Fernández, 1966 y 1975, 212-225), "el contenido de los pozos manantiales de llici parece hoy una colmatación consciente de un sistema hidráulico que había dejado de funcionar" (Abascal, 2004, 93). 
fica como un mausoleo, aunque también se ha supuesto que se trate de sólidas dependencias de etapas anteriores reaprovechadas como lugar de enterramiento (Tendero y Lara, 2004, 132). Ambas opciones no están reñidas puesto que una estructura ya existente puede ser convertida en mausoleo y distribuida en un nivel inferior como lugar de enterramiento y otro superior para funciones tales como el acceso o la representatividad social ${ }^{36}$. En cualquier caso la decoración afectaba a ambos niveles, de acuerdo con la nota "pared también con estucos pintados" observable en el correspondiente croquis (Fig. 3) para una de las inferiores.

El análisis de las fotografías de Alejandro Ramos de aquella excavación permite constatar, además, la existencia de seis columnas a lo largo de su pasillo central (Fig. 13), lo que refuerza la idea de un segundo nivel al que las columnas -reales o de obra- servirían como soporte, y quizás entonces los ladrillos horizontales no serían sino parte del piso superior. De ser el caso, en el croquis realizado a pie de excavación (Fig. 3) se intuye la presencia de un escalón en el extremo suroriental o final de la $L$, quizá el último resto del acceso al nivel inferior. Desgraciadamente no conocemos la posición de ningún cadáver pues este -de momento probable- mausoleo se halló saqueado, sin restos óseos ni ajuares (Ramos, 1962, 91).

Para el resto de tumbas, de acuerdo con la información ya citada de los diarios de excavación de Alejandro Ramos, 19 sepulturas -15 individuales, 1 doble y 3 infantiles- se organizaban regularmente y con suficiente espacio entre ellas como para pensar en algún tipo de señalización exterior, puesto que en ningún caso recortan ni se solapan a otras anteriores (Fig. 14), y sólo una sin numerar se hallaba desplazada, amontonados sus huesos (vid. Diario 25-V-1953). Todas, salvo una de las infantiles paralela a un muro

36. Recordemos al respecto el mausoleo de Orriols en Valencia, con unas medidas de 4’40 x 3,80 m y una datación entre finales del siglo III y principios del IV, cuyas "inhumaciones, que aparecieron a 1'80 metros de profundidad de la rasante de la calle, se realizaron con sepulcros de plomo, separadas por muretes y cubiertas por losas. Por encima de éstas D. José Llorca encontró restos humanos, por lo que plantea la hipótesis de que el mausoleo tuviera dos pisos" (Albiach y Soriano, 1996b, 125). En 1995 en los alrededores se localizó una necrópolis, con un par de construcciones funerarias, una de 1'38 x 2'86 m y otra peor conservada, de 2'76 x 3'36 m y ocho tumbas de unos $2 \mathrm{~m}$ de longitud y entre 48 y $60 \mathrm{~cm}$ de anchura, con cubierta de tegulae, con una cronología general de principios del III hasta el IV.

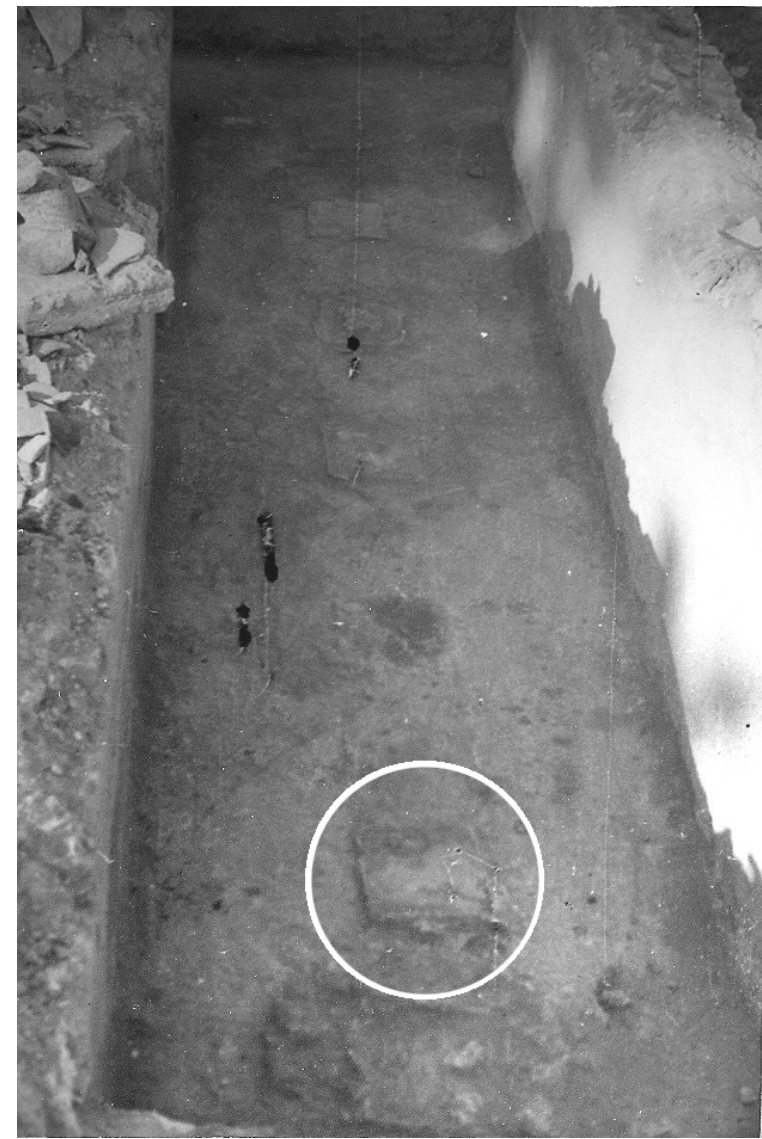

Figura 13: Restos de la columnata (remarcada la primera de las 6 columnas) del pasillo del posible mausoleo del Borrocat (Foto A. Ramos).

norte-sur, se orientaban Este a Oeste, con la cabeza al Oeste cuando fue posible identificarla, y tan sólo dos de las inhumaciones individuales de adultos -números 2 y 12-disponían de ajuar.

Según lo indicado el 7 de marzo de 1953 las doce primeras sepulturas se definían como: "fosa abierta rompiendo el trespol romano, y luego, con losas y piedras de varia clase construyeron unos muretes laterales; cubren estas sepulturas, losas escuadradas o simples piedras". Tanto los croquis como las descripciones del resto de enterramientos concuerdan con lo dicho, así como lo hace la memoria de excavación cuando precisa: "todas ellas construídas con losas de sillería los lados y cubiertas con otras iguales" (Ramos, 1962, 91). Sin embargo, Alejandro Ramos publicó más tarde que "como tapadera en algunas ocasiones se utilizaban ladrillos de grandes dimensiones, de forma cuadrada" y que "también las había abiertas en un gran bloque de piedra en el que habían hecho el hueco suficiente para alojar el cadáver, siendo en este caso la tapadera de una sola pieza" (Ramos, 1970, 74), datos que en ningún caso aparecen en sus dia- 


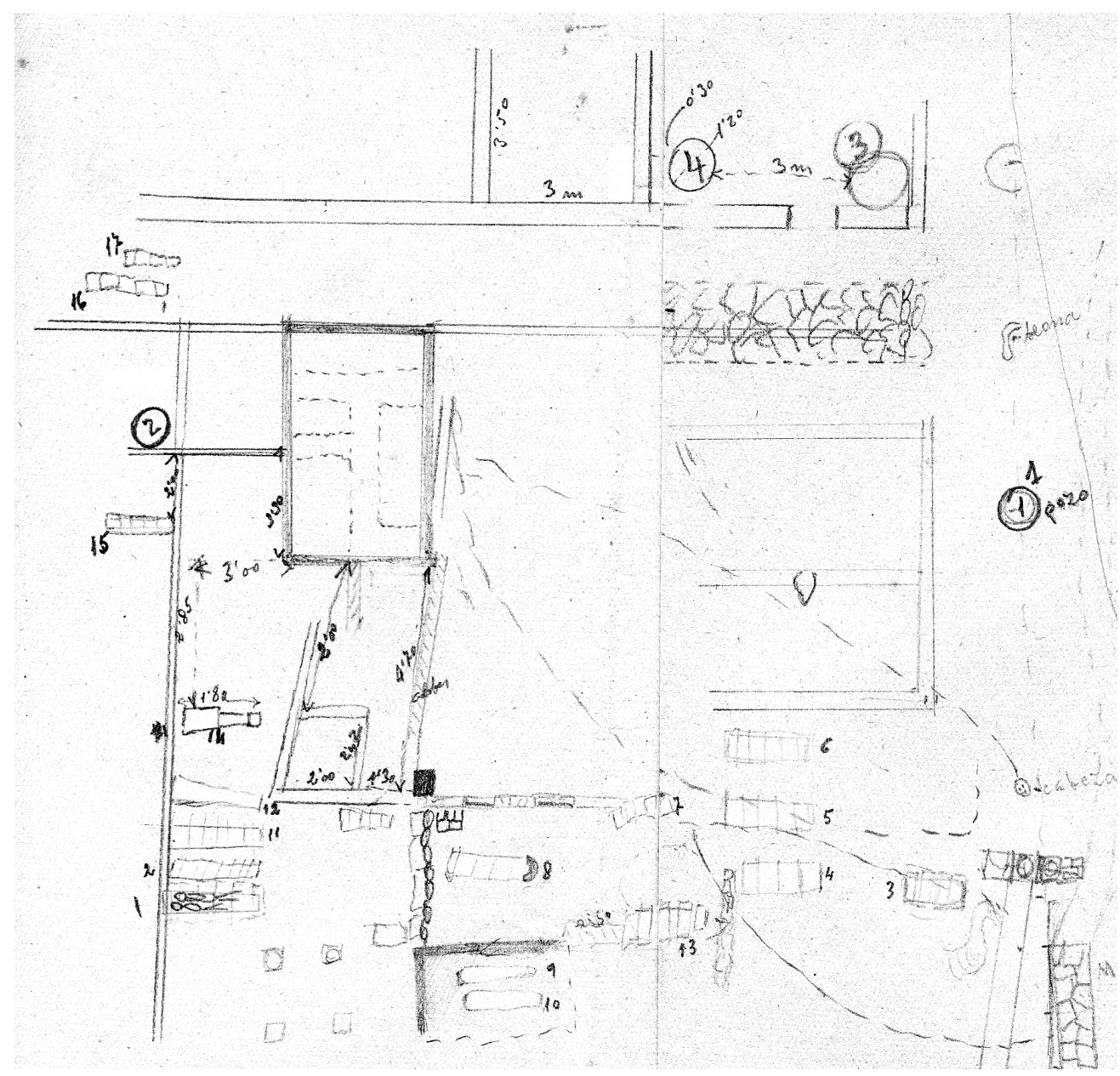

Figura 14: Croquis de A. Ramos de la excavación en 1952-1954 de la necrópolis del Borrocat, con las 20 tumbas que mencionan sus diarios remarcadas en amarillo.

rios. Más adelante llegó a hablar de aparecer "cubiertas muchas de ellas por ladrillos rojos cuadrados, salvo una de ellas labrada la caja en piedra en una pieza así como la tapadera a dos vertientes" (Ramos, 1974, 152). Si estas referencias posteriores no son un error de Alejandro Ra- mos al compilar dos obras de carácter general, así heredado por la bibliografía actual (vid. Reynolds, 1993, 65; González, 2001, 402), entonces deben ser el resultado del descubrimiento y la excavación en años posteriores de nuevas sepulturas cubiertas con ladrillos y no con losas, y
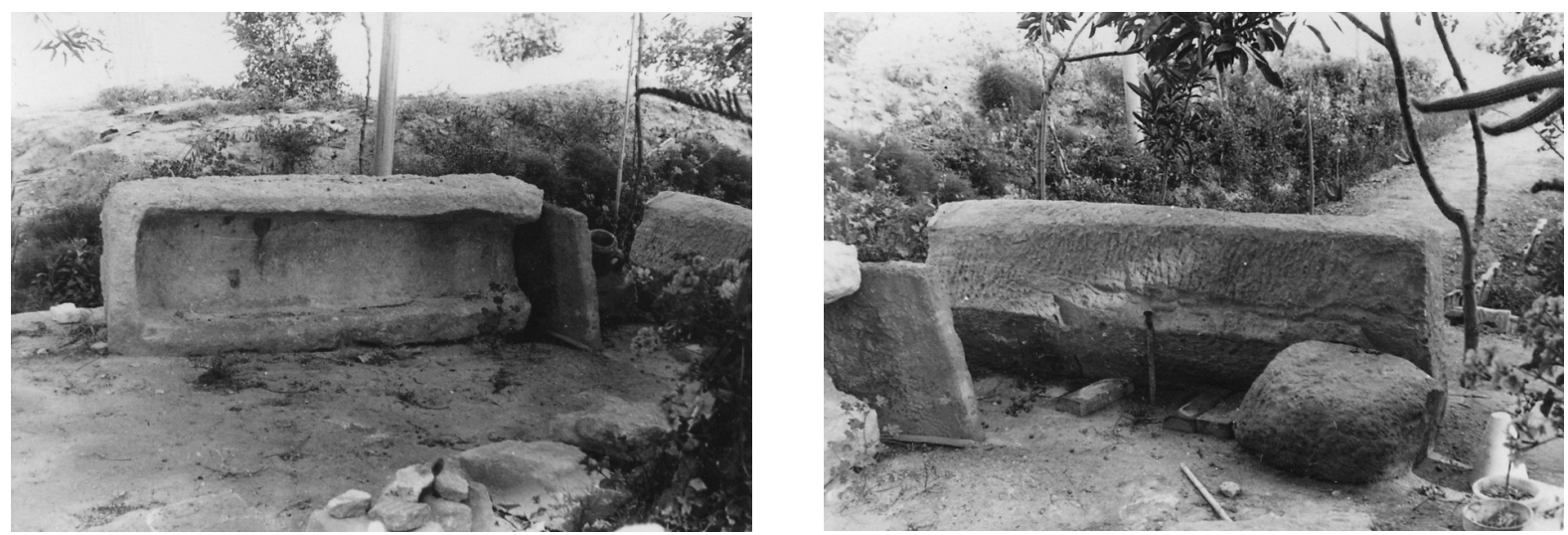

Figura 15 a y b: Sarcófago con cubierta a dos aguas de la necrópolis del Borrocat (Fotos A. Ramos). 


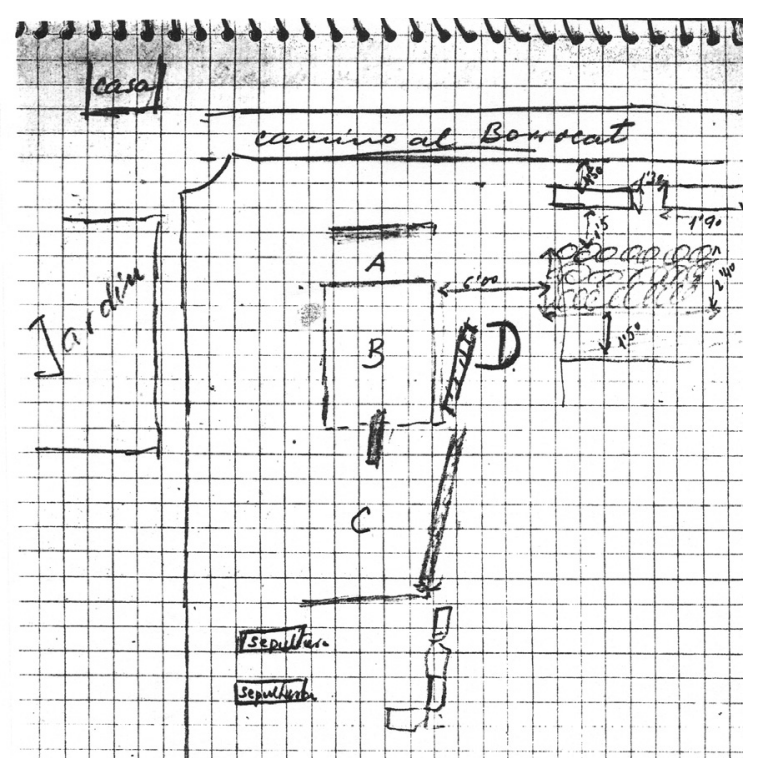

Figura 16: Croquis de A. Ramos de la ubicación de las excavaciones de 1952-1954 respecto de su casa y jardín, en que "B" representa el posible mausoleo.

nunca mencionadas. Pero, además, se incide en la existencia de un sarcófago, de aparición confusa para Ricardo González Villaescusa ${ }^{37}$, que bien podría tratarse de alguna de las "cajas de piedra" halladas en 1925 que Alejandro Ramos conoció durante años en el jardín de su madre (Fig. 15 a y b).

37. "Se trata de un hallazgo de cierta magnitud ya que es uno de los escasos ejemplos del País Valenciano de sarcófagos monolíticos trabajados en un único bloque de piedra arenisca y con tapa. Fruto de las excavaciones realizadas en los años 40 por A. Ramos Folqués, las circunstancias de su hallazgo son confusas pues, si bien es cierto que debió encontrarse en las campañas de 1945-1946, no hemos podido recoger la referencia bibliográfica que lo confirme; así, las memorias de excavaciones realizadas en La Alcudia publicadas en el Noticiario Arqueológico Hispánico de esas fechas -volúmenes III, IV y V del N.A.H.no recogen datos de este enterramiento, aunque, por el contrario, sólo lo hacen de la necrópolis visigoda. Será en una publicación más moderna, donde $\mathrm{A}$. Ramos hará referencia al cementerio paleocristiano de la Alcudia. En su Historia de Elche [...] al describir el sarcófago que nos ocupa hace alusión a un monumento funerario que ya había sido descrito en la memoria de 1953 [...], pero en ella no se hace referencia al sarcófago. Sin embargo, los problemas no terminan aquí; en la publicación citada [...] no se identifica el ajuar [...] Sin hacer alusión a una soberbia y excepcional pieza de vidrio que años más tarde aparecerá siempre asociada a este enterramiento [...]. Años más tarde, en una publicación sobre el vidrio romano de la provincia de Alicante se recoge esta pieza [...] dudando de su pertenencia a la necrópolis de los siglos IV-V d. de C. por razones de coherencia cronológica, ya que un paralelo de la misma aparece en un contexto bien diferenciado, fechado en el siglo VII[...]" (González, 2001, 401).

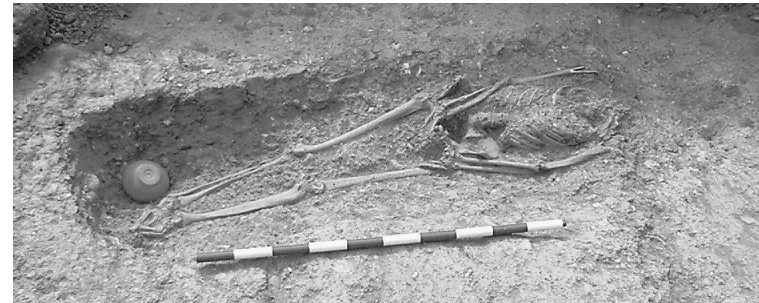

Figura 17: Enterramiento en fosa simple de la necrópolis del Borrocat. (Foto Alebus SL).

En efecto, por las Efemérides 1928, 1931 y 1935 de Pere lbarra, referidas a principios de 1925 , sabemos que en un bancal "enfrente de la casa, linde del caminito del jardín", es decir, a pocos metros de las sepulturas más occidentales excavadas en 1952-1953 (Fig. 16), aparecieron cuatro "cajas de piedra". Uno de los sarcófagos medía 217 x $47 \mathrm{~cm}$, y $32 \mathrm{~cm}$ de profundidad, con dos enterramientos y ningún ajuar, mientras que sólo en uno de los otros tres se halló un ungüentario de vidrio de unos $12^{\prime} 5 \mathrm{~cm}$ de altura muy bien conservado $^{38}$. De más difícil interpretación como sarcófagos son las dos "sepulturas de piedra", una de ellas con esqueleto y un anillo de plata como ajuar, aparecidas en 1897 (vid. Efeméride 126) a $8 \mathrm{~m}$ al oeste de la entonces "casita de la loma", cuyo jardín supuso en 1952-1953 el límite oeste de las excavaciones -por tanto distanciada unos $30 \mathrm{~m}$ de las tumbas más occidentales del sector 6-F, pero tan sólo a 10-15 m de los sarcófagos aparecidos delante de "villa Illice" en 1925-.

También tenemos dos inhumaciones en fosa simple. Una es un esqueleto aparecido en 2002 en el hipocausto de las Termas Orientales, que, contra la opinión de sus excavadores ${ }^{39}$, sí podría tratarse de un enterramiento más de esta gran necrópolis tanto por la orientación del cuerpo como por su localización. La otra es la do-

38. Los $12^{\prime} 5 \mathrm{~cm}$ de altura que proporciona Pere Ibarra (efeméride 1935) para este "violetero o florero de vidrio" aparecido en 1925 en un sarcófago no permiten identificarlo con el famoso ungüentario que menciona la nota 37 (Fig.19) (publicado por primera vez en: Ramos, 1953, figura 21), aunque quizá expliquen el recuerdo familiar de Alejandro Ramos del objeto guardado por su madre y la errónea atribución del unguentario más alto a otro o al mismo sarcófago, el de cubierta a dos aguas.

39. "Entre el material de derrumbe encontrado en el interior de este hypocaustum aparecieron restos de un esqueleto humano orientado de este a oeste que más que enterrado parece haber quedado atrapado entre los escombros en el momento de la destrucción del edificio", indican Rafael y Alejandro Ramos (Tendero y Pastor, 2003). 


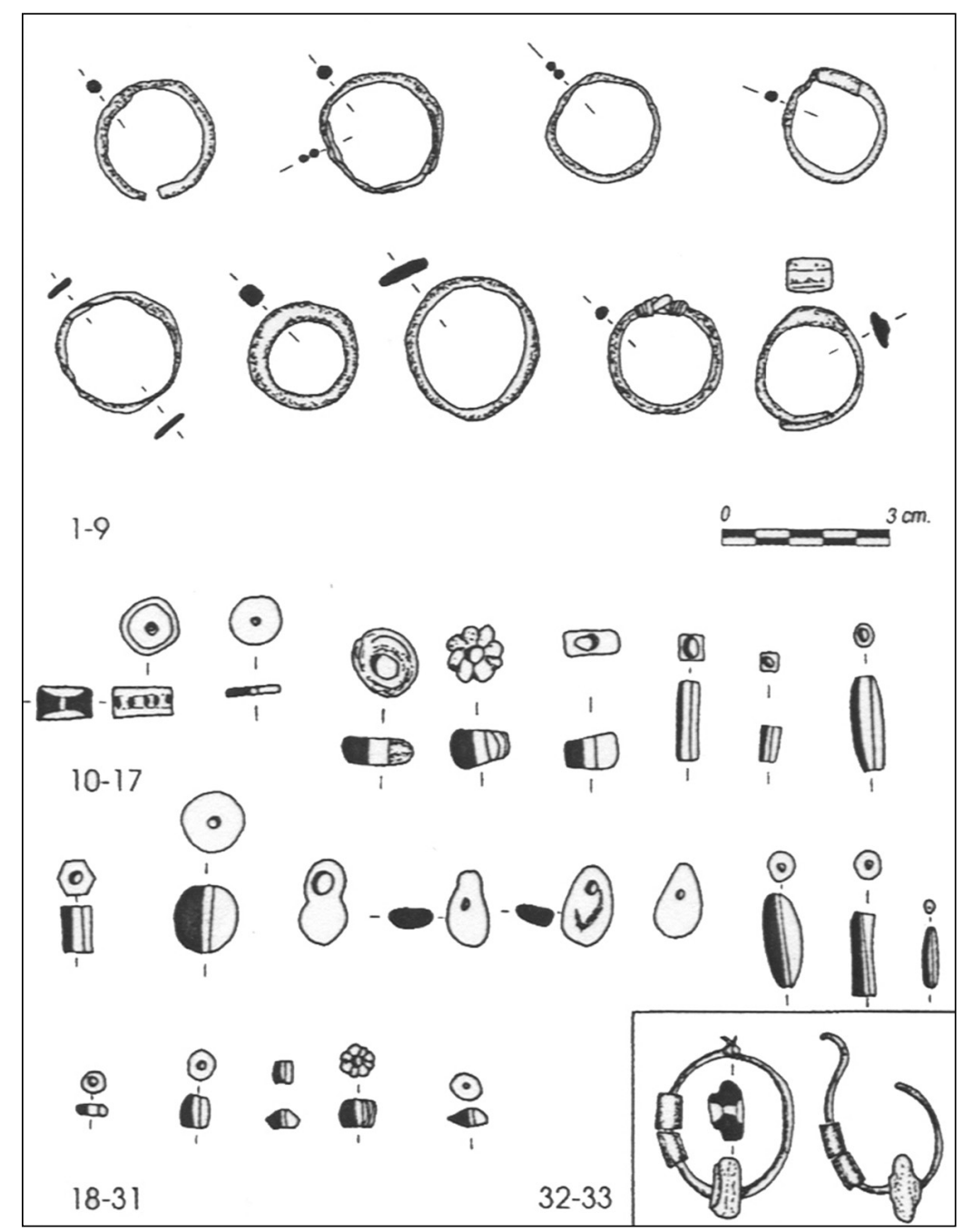

Figura 18: Ajuares de las sepulturas 2 y 12 de la necrópolis del Borrocat dibujados por R. González Villaescusa (2001).

cumentada en 2003 por el equipo de Alebus SL inmediata al sector 6-F de l'Alcúdia pero en el exterior del yacimiento, sin piedras que la delimiten ni superestructura alguna que la identifique como tal, con un enterramiento individual en decúbito supino y un ajuar a los pies consistente en una pequeña escudilla cerámica que contenía un ungüentario de vidrio (Fig. 17).

Con esta información obtenemos cinco tipos de tumbas, ordenadas de acuerdo a la monumentalidad o entidad de sus materiales constructivos:

Tipo 1. Posible mausoleo organizado como cripta con un pasillo en forma de $L$ para acceder a los huecos destinados a las sepulturas, así como con un nivel superior - $i$ al nivel de la circulación?- decorado con estucos pintados.

Tipo 2. Sarcófagos toscos compuestos "por un gran bloque de piedra en el que habían hecho el hueco suficiente para alojar el cadáver, siendo en este caso la tapadora de una sola pie- za" (Ramos, 1970, 64). Corresponden a este tipo las cuatro "cajas de piedra" aparecidas "enfrente de la casa, linde del caminito del jardín" en 1925 (vid. Efemérides 1928, 1931 y 1935), una de ellas con un ungüentario de vidrio como ajuar. Un único caso es un enterramiento doble.

Tipo 3. Tumbas de tendencia rectangular construidas mediante losas de piedra laterales y cubiertas por otras iguales. El cadáver siempre en decúbito supino y sin ajuares salvo dos excepciones con collares, sortijas y pendientes (Ramos, 1962, 91). Un único caso es un enterramiento doble.

Tipo 4. Tumbas de tendencia rectangular construidas mediante losas de piedra laterales y cubiertas por ladrillos cuadrados. Posición del cadáver y ajuares desconocidos (Ramos, 1970, 74; y 1974, 152).

Tipo 5. Tumbas de fosa simple, sin piedras que la delimiten ni superestructura alguna que la identifique como tal, con un enterramiento indivi- 
dual en decúbito supino y un sencillo ajuar a los pies.

Los sarcófagos monolíticos sin ningún tipo de decoración ${ }^{40}$ del tipo 2 son perfectamente equiparables al tipo 3 de la necrópolis del Torrero de amplia distribución temporal, mientras que Ricardo González Villaescusa $(2001,403)$ indica que la cubierta a doble vertiente con los extremos suavizados del polémico ejemplar expuesto en el Museo Monográfico de la Alcudia (vid. nota 37) es propia de los siglos IV-V y usual en cementerios ad sanctos ${ }^{41}$. En cualquier caso el individuo allá enterrado (o actualmente expuesto) era un hombre de unos 25-30 años del tipo mediterráneo robusto (González, 2001, Apéndice III.3).

Por otra parte, las sepulturas cubiertas por losas del tipo 3 coinciden con el tipo A de la necrópolis de San Antón en Cartagena, de mediados del siglo IV al VI (Berrocal y Laiz, 1995, 173), así como con las sepulturas 9 y 14 de la necrópolis del Corralón en Los Belones (Cartagena), de los siglos IV-VII (Antolinos y Vicente, 2000, 327). El revestimiento de las paredes con "lajas de piedra" es equiparable al Tipo II genérico de la cuenca del Vinalopó, de los siglos V-VII (Segura y Tordera, 1999).

La cubierta con ladrillos del tipo 4, dudosa para esta necrópolis como se ha expuesto, podría encontrar los mismos paralelos que el tipo 2 de la necrópolis del Torrero, de los siglos IV$\mathrm{VI}$, mientras que las sepulturas en fosa simple coinciden con el subtipo 1. A sin cubierta de la cuenca del Vinalopó, de los siglos V-VII (Segura y Tordera, 1999, 535).

40. Dos sarcófagos visigodos hallados a mediados del siglo XIX en el campo de Arjonilla (Jaén), uno conservado en el Museo Arqueológico de Jaén y otro aprovechado como mesa de altar en la parroquia de Arjonilla (García Bellido, 1973), muestran en su desarrollo un parecido formal razonable con la "placa de cancel" localizada en l'Alcúdia (Ramos, 1974), la cual, por cierto, únicamente muestra decoración en una de sus caras. Pero el fragmento en cuestión parece, por los restos de argamasa conservados, tratarse realmente de restos de un cancel visigodo, por lo que de momento no hay ningún sarcófago decorado en l'Alcúdia -el del siglo II con el motivo del rapto de Proserpina en bajorrelieve sabemos seguro que no llegó y naufragó en las costas del Portus ilicitanus, y no hay más testimonios al respecto-.

41. En el estado actual de la investigación sobre esta necrópolis del Borrocat y la entidad y características del posible mausoleo no puede hablarse de un martyrium -y Ricardo González Villaescusa no lo hace- que organizase una distribución de las tumbas ad sanctos, aunque sí de una cierta organización de las mismas en derredor de dicho edificio.

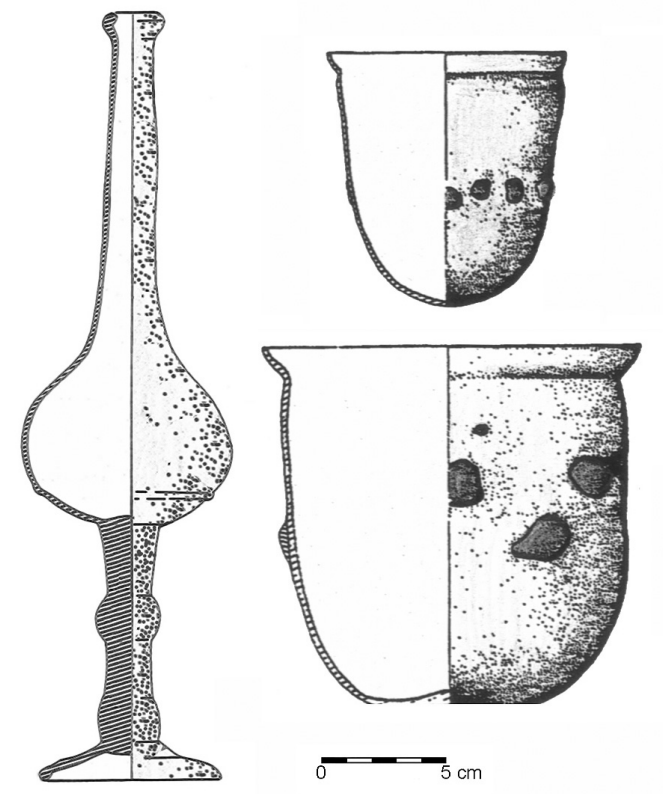

Figura 19: Ajuar tradicionalmente asociado al sarcófago con cubierta a dos aguas de la necrópolis del Borrocat, dibujado por M.D. Sánchez de Prado (2004).

Por tanto, en atención a unos paralelos amplios de los siglos III-VIII, o más reducidos del IV a los siglos VI-VII para el tipo 3, así como diferentes paralelos de los siglos IV-V para los ajuares (Fig. 18) (González, 2001, 403), para esta necrópolis intramuros del Borrocat puede suponerse una cronología más o menos contemporánea a la periurbana del Torrero, lejos de las primeras consideraciones como visigoda (Ramos, 1956, Lám. CIX), si bien no puede descartarse una fase visigoda en el siglo $\mathrm{VII}^{42}$ de acuerdo con los análisis actuales (Sánchez de Prado, 1984, 85; 2004, 221) de las piezas de vidrio tradicionalmente interpretadas como ajuar del sarcófago con cubierta a doble vertiente (Fig. $19)^{43}$. Recogiendo las palabras de Ricardo González Villaescusa $(2001,403)$ "la ubicación del

42. La Ilici tardía se encuentra en una zona alejada del poder real visigodo antes del momento de la conquista bizantina en 554, y totalmente fuera de la órbita toledana desde entonces hasta la caída de Carthago Spartaria hacia el 625. En el futuro habrá que localizar los enterramientos, sin duda privilegiados, de las nuevas autoridades, y quizá se documente la existencia de fases distintas dentro de los mismos espacios, o bien de nuevos emplazamientos, al estilo de las necrópolis de l'Almoina de València, que tanta bibliografía han generado.

43. Basándose en la comunicación personal de Rafael Ramos, Paul Reynolds (1993, 65 y figura 64a-c) atribuye el ungüentario y los dos cuencos de vidrio al sarcófago. 
cementerio, la tipología del sarcófago y del resto de las sepulturas así como la presencia de ajuares de adorno personal, son factores que creemos que nos situan en torno a los siglos IV y $\mathrm{V}$ d.de.C.", al menos para los momentos iniciales de la necrópolis.

Una última reflexión para esta necrópolis, al margen de la preparación previa del terreno y la mayor extensión ya apuntadas, obliga a tratar el posible saqueo de parte de las tumbas constatadas y la desaparición de muchas otras por causa de las remociones en época tardía que suponía Alejandro Ramos en las anotaciones correspondientes a mayo de 1953 y septiembreoctubre de 1954. Tanto el posible mausoleo (Ramos, 1962, 91) como un esqueleto sin numerar hallado en la habitación B (Fig. 3) adyacente al mismo ${ }^{44}$ aparecieron saqueados, y de la tumba $\mathrm{n}^{\circ} 12$ se dice que parte de la cubierta apareció caída a un lado y el esqueleto desecho -aunque, paradójicamente, es una de las dos únicas en que se halló ajuar, si bien al cribar la tierra-. Por tanto, por la disposición regular que presentan las tumbas conservadas, puede pensarse que muchos de los espacios vacíos entre ellas en realidad estaban ocupados por sepulturas que fueron saqueadas, perdiendo la cubierta y aquellos otros elementos que, al favorecerse la desaparición del esqueleto, ya no permitieron a Alejandro Ramos identificar las piedras allí revueltas como fosas o sepulturas ${ }^{45}$.

\subsection{Necrópolis de la basílica, en l'Alcúdia $\left(38^{\circ} 14^{\prime} 15 » \mathrm{~N}, 0^{\circ} 41^{\prime} 44 » \mathrm{~W}\right)$}

La otra única necrópolis intramuros constatada hasta ahora en l'Alcúdia, tratada en segundo lugar por su aparente menor entidad y posterior cronología, es la descubierta por Alejandro Ramos en 1950 al ampliar las operaciones a levante de la basílica pavimentada de mosaico reexcavada el año anterior. Aunque "la incertidumbre rodea las circunstancias exactas del hallazgo" y

44. "Allí debieron encontrar una sepultura cuyo esqueleto fue luego enterrado allí, amontonando los huesos" (Diario A.Ramos, 25-V-1953).

45. Un ejemplo muy actual de saqueo importante, pero que no afecta a la totalidad de las tumbas, lo hallamos en la basílica septentrional del conjunto paleocristiano de Francolí en Tarragona (López Vilar, 2006), en la que los excavadores proponen una distribución de las tumbas por el espacio cementerial a partir del análisis de la ocupación del mismo por las tumbas conservadas y por los restos de las saqueadas, pero también del vacío dejado por otras totalmente desaparecidas.

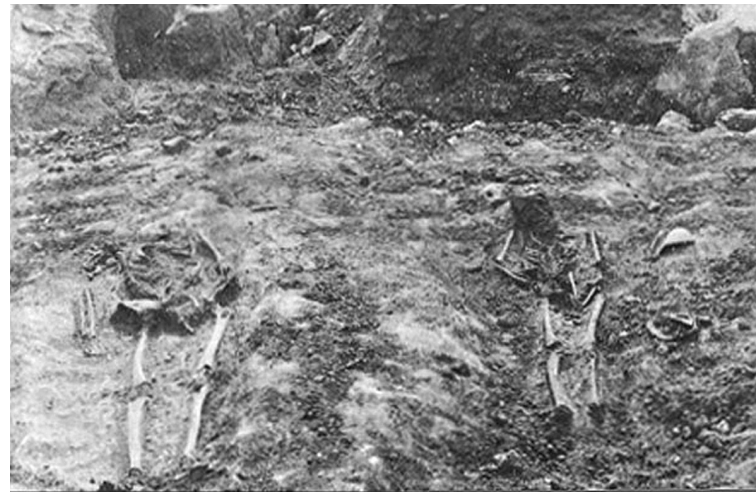

Figura 20: Tumbas en fosa simple de la necrópolis de la basílica (Ramos, 1956, lámina CIX).

"la bibliografía aporta datos que, si bien no son contradictorios, ofrecen algunas dudas de coherencia textual" (González, 2001, 404), siguiendo la descripción de su excavador tenemos unos enterramientos caracterizados por una gran simplicidad, sin "restos ni huellas de madera, clavos ni otros indicios de cajas o féretros para su enterramiento" (Ramos, 1956, 107), mientras que "los esqueletos se hallaban sobre la tierra, en dirección este-oeste, estando la cabeza al este" (Ramos, 1972, 171). Prácticamente no había ajuares "pues sólo se han encontrado fragmentos de vasijas muy bastas" (Ramos, 1956, 107) y un par de pendientes (Fig. 18, 32 y 33), y todas las fosas eran de reducidas dimensiones (Fig. 20).

De acuerdo con estos datos, y con los proporcionados por los diarios de excavación, Alejandro Ramos descubrió hasta cinco sepulturas inmediatas al ábside de la basílica cristiana, una de ellas doble con un adulto y un niño (Fig. 21), orientadas con la cabeza al este. Esta disposición extraña y minoritaria, tanto para el contexto de la cuenca del Vinalopó (Segura y Tordera, $1999,535)$ como de manera general -por ejemplo tan sólo supone el 1 '71 \% de las 485 tumbas excavadas del cementerio meridional de Empúries (Nolla, 1995, 103)-, resulta coherente con una organización orientada, no a Jerusalén ni al sol naciente, sino hacia la sacralidad que del propio ábside se suponía emanaba: una necrópolis ad sanctos. Los enterramientos de este tipo -en torno o incluso dentro de las iglesias- resultan bastante comunes a lo largo de los siglos IV al VIII (Palol, 1967; Puertas, 1975; Godoy, 1995) pese a las prohibiciones conciliares existentes.

Por otra parte, el propio Alejandro Ramos $(1956,107)$ ya sugirió una mayor extensión para esta necrópolis pues observó que los enterramientos conservados, "todos ellos deteriorados 
seguramente a causa de las labores agrícolas, dada su proximidad a la superficie", se habían "conservado por hallarse entre árboles viejos", considerándolos tan sólo "parte de una necrópolis visigoda destruída por las labores agrícolas". No hay duda de que la necrópolis ad sanctos se vió muy afectada por las actividades agrícolas a que se dedicó el yacimiento la primera mitad del siglo XX, y que sufrió la aparición de las rejas mecanizadas que perfectamente podían roturar el terreno a una profundidad superior a los 10-25 $\mathrm{cm}$ en que se encontraban las tumbas. El hecho mismo de que las pocas excavadas se encontrasen al amparo de aquellos "árboles viejos" es una prueba indirecta de la probable destrucción de muchas otras que no gozaron de dicha protección, y conservamos testimonios aislados de enterramientos a unos $50 \mathrm{~m}$ al este de los anteriores $^{46}$.

Sobre la cronología, puede asegurarse que esta necrópolis no corresponde al tipo de las de Herrera del Pisuerga (Palencia) o Castiltierra (Segovia), como mantuvo inicialmente Alejandro Ramos (1956, 107), sino que su disposición resulta muy diferente a aquellas grandes extensiones de tumbas. Con ello nos quedamos sin el único argumento cronológico esgrimido por su excavador -siglos VI-VII-, aunque de manera genérica ha sido ubicada entre los siglos V-VIII (Gutiérrez, 1988, 333; Segura y Tordera, 1999, 534). Como paralelos cercanos, las cinco tumbas de fosa sim-

46. "Próximo al lugar donde fue hallado el busto de la Dama, o sea al noroeste, y a $100 \mathrm{~m}$. de aquel lugar", donde "se hallaban casi al descubierto restos de paredes" (Ramos, 1966, 75) Alejandro Ramos encontró, en una perforación del signinum que conformaba el suelo de una habitación, un conjunto formado por "dos pondus de barro cocido, una anforita y cuatro vasijas incompletas, todas ellas de barro basto de color amarillento. Junto a estas vasijas un esqueleto humano". Años después, Josep Gisbert interpretó el hallazgo como un contexto funerario, y para la anforita vió «indudables paralelismos con las del interior de la Península Ibérica de cronología visigoda" (Gisbert, 1986, 207), con una datación en el siglo VII, aunque sin descartar la segunda mitad del VI, de plena influencia visigoda. Si tenemos en cuenta que la basílica se encuentra a $158 \mathrm{~m}$ "al Oeste del punto mismo en que fue hallado el famoso busto" (Ibarra Ruíz, 1906, 121), y dicho hallazgo apareció "próximo al lugar donde fue hallado el busto de la Dama, o sea al noroeste, y a $100 \mathrm{~m}$. de aquel lugar" (Ramos, 1966, 75), no tendríamos más que unos 50 ó $60 \mathrm{~m}$ de distancia al ábside, y podría tratarse de un enterramiento que, al perforar el signinum, quedó protegido del arado y, por tanto, nos daría testimonio de una gran extensión para la necrópolis asociada a la basílica, aunque podríamos también hallarnos ante un enterramiento aislado $u$ otro grupo de sepulturas desaparecido y no vinculado con las tumbas ad sanctos.

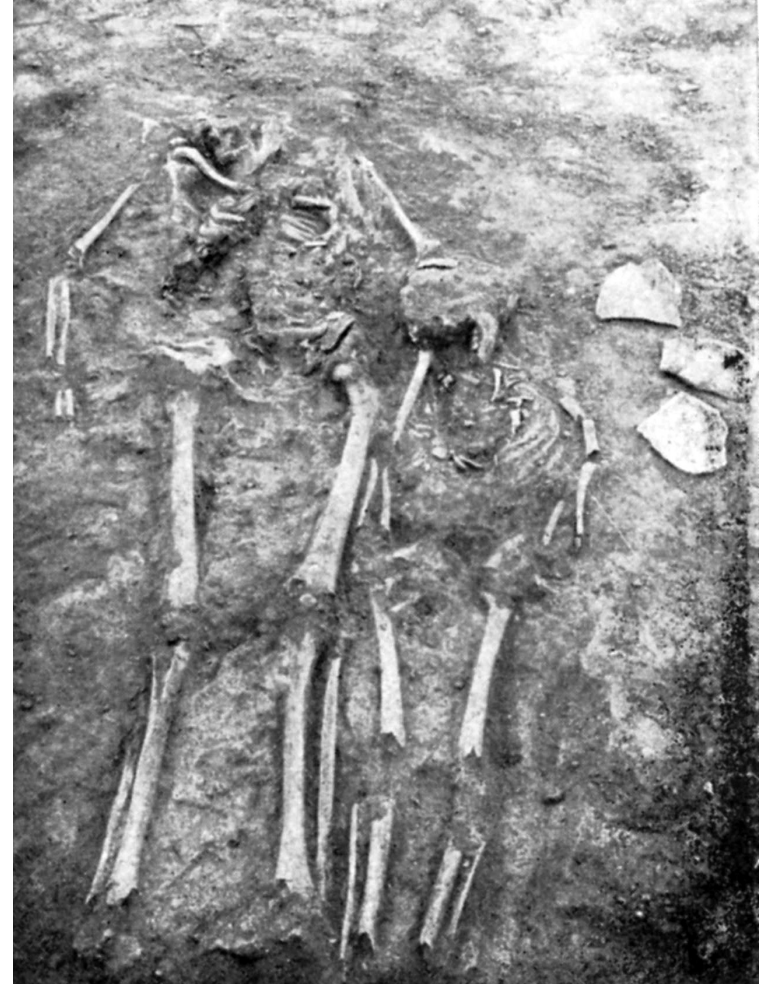

Figura 21: Tumba doble de la necrópolis de la basílica (Ramos, 1956, lámina CIX).

ple $^{47}$ coinciden con el Subtipo 1.A sin cubierta de la cuenca del Vinalopó, de los siglos V-VII (Segura y Tordera, 1999, 535). Por otra parte, los pendientes "en forma de aro y con un adorno perforado de pasta vítrea" (Ramos, 1956, 107) hallados junto a la cabeza de uno de los cadáveres, se han datado, a partir del estudio de paralelos formales, en los siglos VI-VII (González, 2001, 405), una cronología que Ricardo González Villaescusa $(2001,405)$ extiende al conjunto de la necrópolis ad sanctos, reforzada además por alguna pieza cerámica quizás aparecida en alguna de las tumbas así como por el tipo de enterramiento, lo que corrobora la primera suposición de Alejandro Ramos.

47. Aunque en las memorias publicadas nada se dice al respecto (Ramos, 1955 y 1962), sino más bien todo lo contrario -»[...] sin que hayamos encontrado vestigio alguno de sepulturas construídas con piedras» (Ramos, 1970, 70)-, Juan Carlos Márquez y Antonio Poveda $(2000,195)$ -quizá por comunicación personal de los excavadoresindican que en los alrededores de la basílica "se hallaron sepulturas en fosa y sarcófagos monolíticos con cubierta a dos aguas y elementos de adorno personal en los enterramientos" (la cursiva es mía). Podría tratarse de un error debido a la existencia de sarcófagos en la Necrópolis del Torrero (Ibarra, 1879, 167-168), o en la del Borrocat (Efemérides de Pere Ibarra; Ramos, 1962, 91; 1970, 64), que hubiesen sido traspapelados. 
Con esta datación nos hallamos ante una doble interpretación, ya que llici formó parte de la Spania bizantina desde mediados del siglo VI hasta la conquista visigoda de Cartago Spartharia y su zona de influencia (ca. 625). De pertenecer al siglo $\mathrm{VI}$, o principios del VII, la necrópolis correspondería a la fase bizantina de Ilici, mientras que si pudiera ubicarse en momentos más avanzados del siglo VII debiéramos relacionarla con la fase visigoda de la ciudad y quizás relacionar su existencia ad sanctos con las reformas efectuadas en la propia basílica -introducción de canceles y celosías de clara factura visigoda (Schlunk, 1948)- en este momento.

Sobre la fosa documentada en el ángulo interior sudoeste de la basílica, inmediatamente anterior a la pavimentación musiva del edificio -pues la argamasa que acogió al mosaico cuajó directamente sobre las piedras que formaban su cubierta (Figs. 6 y 7)-y, por tanto, contemporánea a la propia conformación de la basílica como tal, la inexistencia de restos documentados en su interior así como su pequeño tamaño, de aproximadamente un metro y medio, no nos permite catalogarla como un enterramiento - ¿quizás infantil? - sin dejar un espacio a la duda, quedando a la espera de algún otro descubrimiento futuro que aclare la cuestión. No obstante, algunas sepulturas de cubiertas intactas excavadas de antiguo en l'Alcúdia -vid. las efemérides de Pere Ibarra- o por Alejandro Ramos en el sector 6-F, no conservaban tampoco resto óseo alguno, o bien éstos se encontraban en tan mal estado que fue imposible recuperarlos -"algunos vestigios" (Ibarra, 1879, 168)-, por lo que no resultaría extraño que esta nueva fosa fuese realmente una tumba. De ser así, las fosas delimitadas con cantos rodados y mampostería en otras necrópolis cercanas se desarrollan a lo largo de los siglos IV-VI (Soriano, 1989, 410), aunque en este caso podemos relacionarla claramente con el momento de la construcción del pavimento de mosaico, probablemente a lo largo de la segunda mitad del siglo IV (Lorenzo, 2005), y desvincularla del resto de enterramientos ad sanctos por ubicación, tipo constructivo y cronología ${ }^{48}$.

48. La imagen de un enterramiento infantil en un ángulo del edificio que sus padres pensaban destinar a basílica cristiana, realizada en el instante previo a la pavimentación con el famoso mosaico, de manera sencilla y sin señalizar su situación pero obteniendo el mismo resultado de lograr un lugar privilegiado de enterramiento, viene clara a la mente. Pero al estado actual de la investigación no resulta más que una elucubración que no puedo evitar reproducir aquí, aún a riesgo de ultrapasar la línea de lo científico.

\subsection{Necrópolis del Campo de Experimenta- ción Agrícola ( $\left.38^{\circ} 15^{\prime} 07 » \mathrm{~N}, 0^{\circ} 41^{\prime} 51 » \mathrm{~W}\right)$}

Gracias al testimonio de Alejandro Ramos en su Mapa arqueológico del término municipal de Elche ${ }^{49}$, sabemos que "en la carretera de Dolores apareció un cementerio de incineración donde las urnas se encontraban alineadas a ambos laterales de una avenida de grava sobre un firme de tierra" (González, 2001, 121). La información sobre dicha necrópolis de incineración se completa en el mismo artículo (Ramos, 1953) con una referencia a la presencia de "muchos esqueletos en la misma posición, es decir, con la cabeza a poniente, del lado derecho, mirando al mediodía", con lo que ya tenemos urnas funerarias cerámicas de tradición ibérica, urnas de plomo de plena concepción romana y bastantes esqueletos en decúbito lateral derecho aunque

49. "Los numerosos hallazgos de urnas cinerarias del período hispánico cubren un terreno que se extiende en línea paralela al Vinalopó, desde las inmediaciones de Elche hacia La Alcudia y cruzando ésta en dirección al Puerto Illicitano. De la mayor parte de estos yacimientos tenemos solamente la noticia escueta del hallazgo de las urnas, hallazgos casi siempre casuales que tuvieron lugar al trazar la carretera de Elche a Dolores o al efectuar labores agrícolas; pero hay dos yacimientos de los cuales hemos podido reunir varios datos sobre la situación y circunstancias ambientales. Estos son: el Campo de Experimentación Agrícola de Elche y La Alcudia.

En cuanto al primero sabemos que fueron halladas las urnas formando dos hileras teniendo entre ellas un paso o camino de unos cinco metros de anchura de gruesa grava sobre arena; respecto al segundo, al Norte del promontorio de La Alcudia y junto al lugar donde se hallara la cripta, fueron encontradas varias sepulturas, según nos relata Ibarra Manzoni, quien, en presencia de estos monumentos, recordó las vías romanas a cuyos lados se levantaban los monumentos funerarios. Expuestos estos antecedentes y dado que la dirección de la línea de urnas parece dirigirse a este punto de La Alcudia donde probablemente terminara el cardo máximo de la población romana, ¿será muy aventurado suponer se tratase de una vía de las características de las romanas, con los enterramientos a los lados? $Y$ esto supuesto, y teniendo en cuenta que las edificaciones y enterramientos romanos se encuentran frecuentemente construídos sobre otros de culturas anteriores, ¿será no menos atrevido pensar que esta línea de urnas, con vía en medio, fuera la necrópolis de la Illici ibérica? Todavía no hacemos afirmaciones, pero sentamos hipótesis que creemos de algún fundamento y esperamos ver ratificadas por descubrimientos posteriores." (Ramos, 1953, 329-330). 
la "ausencia de datos impide fijar la cronología de éstos" 50 .

En los papeles de Alejandro Ramos conservados en el AFA se conserva un apunte manuscrito "según datos facilitados por el labrador en 7 enero 1938" en el que intuyó la posibilidad de hallarse ante una necrópolis islámica, si bien luego no se decidió a publicarlo. Se observan dos croquis, como si uno fuese la puesta en limpio del anterior, indicando el que parece primero unos "enterramientos de inhumación árabe (?) siglo IV (?)", mientras que el segundo se muestra más impreciso y apunta "necrópolis romana o árabe (?) de inhumación". También se habla de "enterramientos en urna siglo I de JC", se remarca la existencia de un camino de tierra de unos cinco metros de ancho, paralelo a la carretera a Dolores, y se indica que "hay que tener en cuenta que en la necrópolis había varios niveles con enterramientos". Otro documento de carácter personal, como es una carta de su hermana Paula, aporta nueva información sobre los enterramientos y algunas de las urnas allí aparecidas, así como sobre el camino de grava, siendo ella la primera persona en suponerlo "la carretera de Illice"51.

50. "Campo de Experimentación Agrícola.- Junto a la carretera de Dolores, apareció una urna cineraria de plomo y otras de barro gris. Este yacimiento es de gran interés por los datos suministrados. De época romana son urnas de plomo conteniendo ungüentarios de vidrio; otras de barro, de grandes dimensiones con vasos de perfumes, a veces con decoración pintada. Un platito de terra sigillata y un gran bronce de Augusto. Todo ello junto a muchos esqueletos en la misma posición, es decir, con la cabeza a poniente, del lado derecho, mirando al mediodía. La ausencia de datos impide fijar la cronología de éstos. Las urnas antes mencionadas aparecieron en hileras a uno y otro lado de una avenida de grava sobre afirmado de tierra." (Ramos, 1953, 344-345).

51. Carta iniciada el 12 de octubre de 1935 de Paula Ramos a su hermano Alejandro, probablemente conservada por éste junto a varios otros papeles de trabajo por hacer referencia a los hallazgos del Campo de Experimentación Agrícola. Su hermana le envía un cacharrete, que "se ha encontrado en el campo de experimentación, ese que hay yendo a llice, pues están cavando un trozo de terreno para poder regarlo y en las excavaciones, se han encontrado una serie de esqueletos, con la particularidad de que todos estan colocados sobre el lado derecho y mirando al mediodia, es decir la cara al sur y la cabeza a poniente. Unos sobre otros, separados solo por tierra pero no mucha, cosa de un palmo o dos. A los pies de uno de esos cadáveres, me dicen que se encontraron 16 cacharritos como este, unos mas grandes y otro mas pequeño. Yo he visto unos cuantos enteros y en dos de ellos he observado que el cuello es de color negruzco. Te pinto la figura 1 [dibujo] para que te des cuenta de lo que le falta al que te mando. Dicen también que se han encontrado algunas ollas, pero que al quererlas sacar se rompieron todas. Pude ver un trozo de olla y creo que es
A partir de la información proporcionada por Paula Ramos sabemos que existía una superposición de enterramientos, separados unos de otros por tan poca tierra - "uno o dos palmos"que las inhumaciones posteriores, "a medio metro del nivel del bancal de olivos" de profundidad, parecen obviar la existencia de las más antiguas, aunque no se habla de cortes ni intromisiones. De un esqueleto se dice que apareció relacionado con una urna que contenía 16 ungüentarios de vidrio, ubicada a los pies o en la cabeza, y es la única referencia sobre posibles ajuares, aunque

igual barro que esa negra que tienes en casa con huesos de ave y un huevo dentro. También me dijo el hombre que me enseñó todo eso, que en otras ocasiones se han encontrado ollas y que una vez se encontraron una de plomo y que D. Pedro Ibarra dijo que eso era cuando la guerra contra illice que debía estar allí el ejército sitiador. De los esqueletos que he visto unos 7 u 8, los hay que estan a medio metro del nivel del bancal de olivos y otros mas bajo. Me dijo mi informador que también se había encontrado ahora una moneda de cobre, pero que todo lo había recogido el ingeniero y que había dicho que no tocasen nada ni siguiesen cavando. Por eso no me traje una botellita de esas enteras y tuve que conformarme con esa. Creo que todo lo que se han encontrado antes y ahora se lo han llevado al museo de Alicante. A Rafael, que estuvo ayer tarde en mi campo se lo dije y dice que si el ingeniero es Torres, que vería si puede recoger una entera. Y nada mas. Si Rafa tiene la maquina y me la deja vere si puedo hacer una foto de los cadáveres si estan aún como los vi. = [otro día] Supongo te habrá dicho la mamá que se encontraron otro trozo de estatua de marmol que es de la del hercules que se encontraron en el fondo. Ayer por la tarde fui con Concha a ver eso de los cadaveres y ya los habían desecho los chiquillos a pedradas desde afuera, pero dotoreando aquello vi que donde estan cavando salia una capa de grava gruesa y al ver que me interesaba por ella, me dijo uno de los que hay alli que eso era una zona que tiene unos 4 metros de ancha, y que seguía hacia unas palmeras que señaló, y que por lo que pude apreciar, es hacia Illice, pues según me enseñó otro trozo donde también habia salió hace años, dice la misma capa, y pienso yo que sería la carretera de Illice. En lo de los cadáveres, tenían cavado sacando restos unos 12 a 15 metros y que creen que deben seguir por bajo de los olivos, lo mismo que esa capa de grava, que va paralela al tajo de los cadaveres. Según me dijo ese de ayer, el cadaver en que se encontró la olla y botellines, era muy grande, y los cacharros salieron a la cabeza y no a los pies como digo antes. Yo, perito en la materia e historiador pulcro y de fama, pienso que es nuestro antiguo conocido Amilcar Vapor (digo Barca) que se le ocurrió ahogarse en la rambla, y que lo enterrarían allí donde enterraron a otros de su ejército. Claro está que puedo equivocarme en estas suposiciones. Salvador me ha dicho que el cacharrete que es mas gordo que lo partido y un poco mas grande es dificil mandártelo por correo sin que te llegue hecho trizas, así que le quito un trocito y te lo mandaré por si quieres estudiar el barro, y si te interesa, no lo rompas ni lo pierdas para poderlo pegar al cacharro cuando regreses [...]". 
parece más lógico pensar que la urna corresponde a un enterramiento de incineración anterior que mucho más tarde quedó adyacente a una de las fosas en que se inhumaron los cadáveres en decúbito lateral derecho. En cualquier caso los 7 u 8 esqueletos vistos por ella -aunque debían ser más y "seguir por bajo de los olivos"- se hallaban dispuestos a lo largo de la via pavimentada con grava y tierra, de 4 ó 5 metros de ancha según las diferentes versiones de los dos hermanos, sin interrumpirla en ningún momento, sino organizados a su lado. La historiografía actual, desde las aportaciones de Vicente Gozálvez (1974), ha confirmado aquella intuición de Paula Ramos y lo más lógico es pensar que nos hallamos ante la via Augusta en el tramo más cercano a su entrada en llici (Reynolds, 1993, 67), a ambos lados de la cual se organizó una necrópolis romana de incineración en época altoimperial, así como una posterior de inhumación que, probablemente por la posición de los cuerpos, Alejandro Ramos sospechó podría ser musulmana.

Característica básica del ritual islámico es la inhumación en decúbito lateral derecho, orientado el cadáver este-oeste -en sentido perpendicular a la Qibla, esto es con la cabeza a poniente mirando a la Meca-, en una fosa directamente excavada en el suelo y sin ningún tipo de ajuar funerario aparte del triple sudario. Puesto que las necrópolis islámicas o maqâbir heredan la localización extramuros, cercanas a las puertas que se abren en la muralla y también junto a los caminos de acceso a la madina, por todo ello cabe apuntar la posibilidad de que los momentos fina-

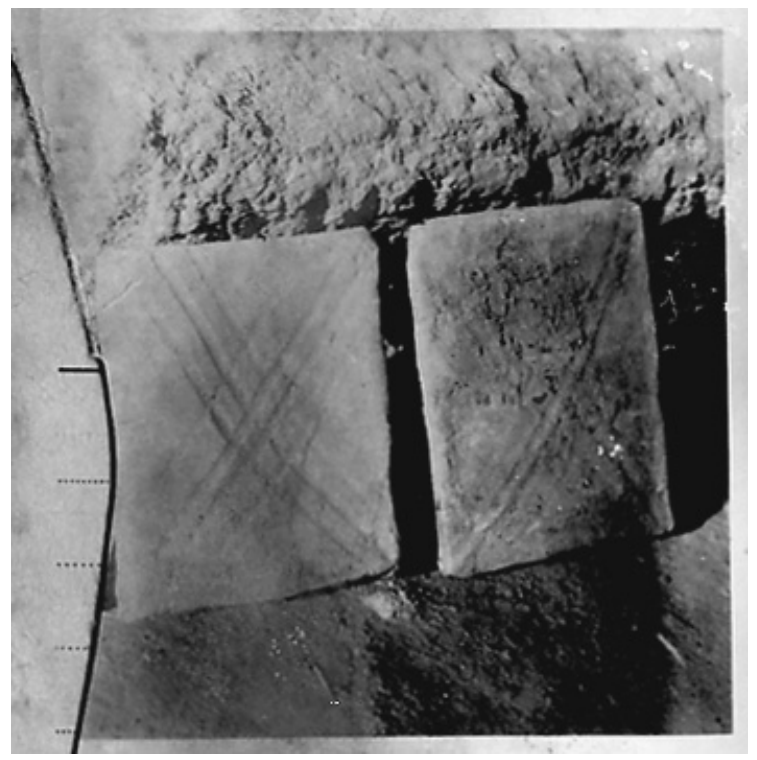

Figura 22: Ladrillos que cubrían las tumbas de la c/ Velarde (Foto P. Ibarra). les de utilización de la necrópolis del Campo de Experimentación Agrícola correspondan a una maqbara. De poderse demostrar en un futuro la adscripción islámica de estas inhumaciones, quedaría aún la duda, por su posición equidistante, de si pertenecerían a la llš que menciona la Cora de Tudmir, ubicada en l'Alcúdia en el siglo VIII (Gutiérrez, 1998), o bien a la otra IIš del siglo $X$ que nacerá en el solar de la vila murada medieval (López Seguí et alii, 2004).

\subsection{Enterramientos aislados}

Complemento a las cinco necrópolis presentadas disponemos de referencias sobre conjuntos funerarios menores o hallazgos aislados tanto en la loma de l'Alcúdia como en los alrededores, pertenecientes a muy distintas cronologías $^{52}$. Por razones de espacio se reseñan sólo aquellos de probable adscripción tardía.

El hallazgo de mayor entidad es el conjunto de enterramientos aparecido en agosto de 1909 en la calle Velarde (vid. Efeméride 656 de Pere Ibarra). Los cadáveres, en número desconocido y sin ningún ajuar, aparecieron a una profundidad de $3 \mathrm{~m}$, superpuestos en filas de tres en tres - ¿seis? ¿nueve?- y "aislados con tejas romanas puestas de plano", un dato que quizá debamos interpretar como cubierta o bien como preparación de la fosa con ladrillos dispuestos planos, pues no se trata de tegulae a juzgar por una fotografía del AFA que indica "Velarde" (Fig.

52. Como muestra un par de referencias sobre enterramientos de época ibérica y romana:

"Al E. del huerto de la Coronela, en propiedad de D. José Torregrosa se ha hallado una hermosa urna funeraria de vidrio azul, encajada muy ingeniosamente en el hueco practicado para contenerla en el interior de un gran cubo de piedra, cubierto de una sólida losa, dentro de la cual se hallaban restos humanos y un As romano de bellísima conservación: y al O. mismo de Elche, antes de llegar al cementerio, en propiedad de nuestro tio, $D$. Juan Ibarra, otro notable enterramiento, consistente en una gran vasija de barro cocido, dentro de la que se conservaban cenizas y restos humanos, en unión del hierro de una lanza, la hoja doblada y rota, al parecer de una espada, el trozo de un gran cuchillo, fragmentos de dos vasijas de metal, con asas movibles, ingeniosamente colocadas, para que aquellas se mantuviesen en equilibrio" (Ibarra, 1879, 207-208).

Alejandro Ramos $(1953,347)$ precisa la primera información con el dato de tratarse del cruce con el canal de Riegos de Levante, en la Coronela, hallándose un tesorillo de 27 semis republicanos y "una urna funeraria de vidrio, encajada en un cubo de piedra cubierto con sólida losa, dentro de la cual había huesos y un as romano". 
$22)^{53}$. La proximidad del conjunto al eje de la centuriación marcado por la calle Filet de Fora, el cual se caracteriza por organizar las necrópolis del Campo de Experimentación Agrícola y del Tio Peix, nos permite relacionar también estas sepulturas de Velarde con la principal via de acceso a llici, la via Augusta, a unos $2500 \mathrm{~m}$ de distancia de la colonia.

En la propia loma Pere Ibarra da la noticia, esta vez no referenciada como Efemérides, de dos importantes enterramientos hallados a finales del siglo XIX que no podemos localizar con claridad. El primero en 1887, una tumba "cerca, muy cerca de la gran "piscina»", "enclavada en el centro de la antiquísima ciudad, como atestiguan los cercanos restos de edificios, columnas, etc.", tal y como la publicó Bernardo Morales (1888, $112)^{54}$. El segundo enterramiento lo registró personalmente Pere Ibarra el 15 de agosto de 1895, de acuerdo al segundo documento transcrito al hablar de las Efemérides perdidas, al que remito para no repetir la descripción.

Muy cerca de l'Alcúdia, en la Hacienda de Porter apareció en 1907 (vid. Efeméride 562) una sepultura asociada a un par de monedas de bronce -una de Filipo el Árabe (244-249)-, y a una inscripción en mármol. Y por la misma zona, junto a un partidor de la tercera elevación de Riegos de Levante cercano al camino del Borrocat, se descubrió en 1914 (vid. Efeméride 1120) a "1 $\mathrm{m}$ del piso del bancal" una sepultura de 2'35 m de longitud, $50 \mathrm{~cm}$ de anchura y $50 \mathrm{~cm}$ de profundidad, con muros laterales de mampostería, ladrillos cuadrados de $23 \mathrm{~cm}$ en la base, y una cubierta con ladrillos de $63 \mathrm{~cm}$ de lado, con restos óseos pero sin ajuar.

53. Alejandro Ramos indica $(1953,348)$ que los esqueletos de Velarde estaban separados con "tejas romanas de plomo", lo que debemos interpretar como un error de la imprenta sobre una anotación original "de plano", en referencia a la posición horizontal de las tegulae.

54. "Cinco sillares dispuestos en órden y formando la cubierta de la sepultura (de una longitud de 2,40 m., siendo el de cada sillar 1,33 m.) Quitados los sillares, en los que no vimos inscripción ó dibujo alguno, apareció un grueso muro, compuesto de dura y compacta argamasa, y colosales ladrillos de barro antiguo, pero de ordinaria labor, recubierto exteriormente de mamposteria; formaba este muro, sobre el cual tenian asiento los sillares, una cavidad rectangular de 2,33 $\mathrm{m}$. largo, 0,60 m. ancho y 0,75 m. de profundidad; su piso era de calicanto durísimo. Se encontraron en ella huesos humanos [...] de las extremidades [...]. Encontróse ademas un plato de barro saguntino con sencillos dibujos, y una moneda de cobre tan deteriorada y borrosa, á causa de la humedad y el tiempo, que fue imposible distinguir su busto y leyenda, perdiendose de este modo tan precioso dato" (Morales, 1888, 112).
En la Hacienda de Ramón Irles ${ }^{55}$ aparecieron en 1918 (vid. Efeméride 1381) una serie de restos arquitectónicos y estructuras interpretables como dependencias agrícolas, de una villa u otra construcción, junto a los cuales se documentó un craneo y otros restos humanos. En la Hacienda de Ramón Espinosa en Carmadet apareció en 1905 (vid. Efeméride 464) una sepultura cuyas paredes las formaban sillares de entre $1 \mathrm{~m}$ y 1 '20 $\mathrm{m}$ de longitud asentados sobre una capa de preparación de cantos rodados, con dos "vinagreras" de bronce como único ajuar destacado. Y finalmente, el hallazgo más curioso se produjo en 1915 en la Foia (vid. Efeméride 1206), en tierras de Francisco Guilló, quien descubrió una gran sepultura cubierta por cinco losas de cantería, cuyo cadáver aún conservaba la vestimenta -que se deshizo en el momento del descubrimiento-, y zapatos "de grandes tacones", y que parecía asociarse a una moneda de oro.

Por su parte, en el Mapa arqueológico del término municipal de Elche Alejandro Ramos menciona la existencia en El Pilar (Atzavares Alt) ${ }^{56}$, propiedad de Vicente Asencio, de una "sepultura formada con losas de barro", probablemente tegulae, así como de "sepulturas romanas" en la Hacienda de Ruiz (Ramos, 1953, 352), y de cerámica ordinaria de época romana, tejas y un esqueleto en la Hacienda de Torregrossa en Algorós (Ramos, 1953, 354). También proporciona información sobre Santa Pola, aunque estos hallazgos no pueden considerarse pertenecientes a las necrópolis própiamente ilicitanas, y "tenemos noticias de que $\mathrm{D}$. José Belda Domínguez, en el

55. La Hacienda de Porter pertenece en 1907 a Ramón Irles Candela, mientras que en 1918 se habla de un Ramón Irles Gomis, por lo que este segundo caso no se refiere a la $\mathrm{H}^{\mathrm{a}}$ Porter, sino que Pere Ibarra explicita $\mathrm{H}^{\mathrm{a}}$ de $\mathrm{R}$. Irles y, además, en la Breve nota de mis Efemérides Arqueológicas Illicitanas (Ibarra, 1926, 163) menciona el segundo apellido para despejar dudas. Paul Reynolds (1993, 60) identifica la $\mathrm{H}^{\mathrm{a}}$ de Ramón Irles Gomis con la Casa de les Teules, ubicada inmediata al sur de l'Alcúdia y origen de uno de los mosaicos actualmente expuestos en el Museo Monográfico de La Alcudia. En este caso, la cercanía entre las dos casas permite suponer un cierto parentesco entre ambos individuos.

56. Aunque nada vuelve a decirse de este hallazgo, y Paul Reynolds $(1993,67)$ lo considera "unlocated", Rafael Ramos $(1975,27)$ habla de otro "El Pilar" localizado en Elche que Paul Reynolds equipara con dudas al topónimo "el Bosquet", el cual tampoco puede ubicar (Reynolds, 1993, 68) si bien es un topónimo actualmente desaparecido que se localiza precisamente en la frontera entre Elche y la partida de Atzavares Alt, por lo que bien podría tratarse de la casa El Pilar de Vicente Asencio en que apareció la sepultura mencionada. 


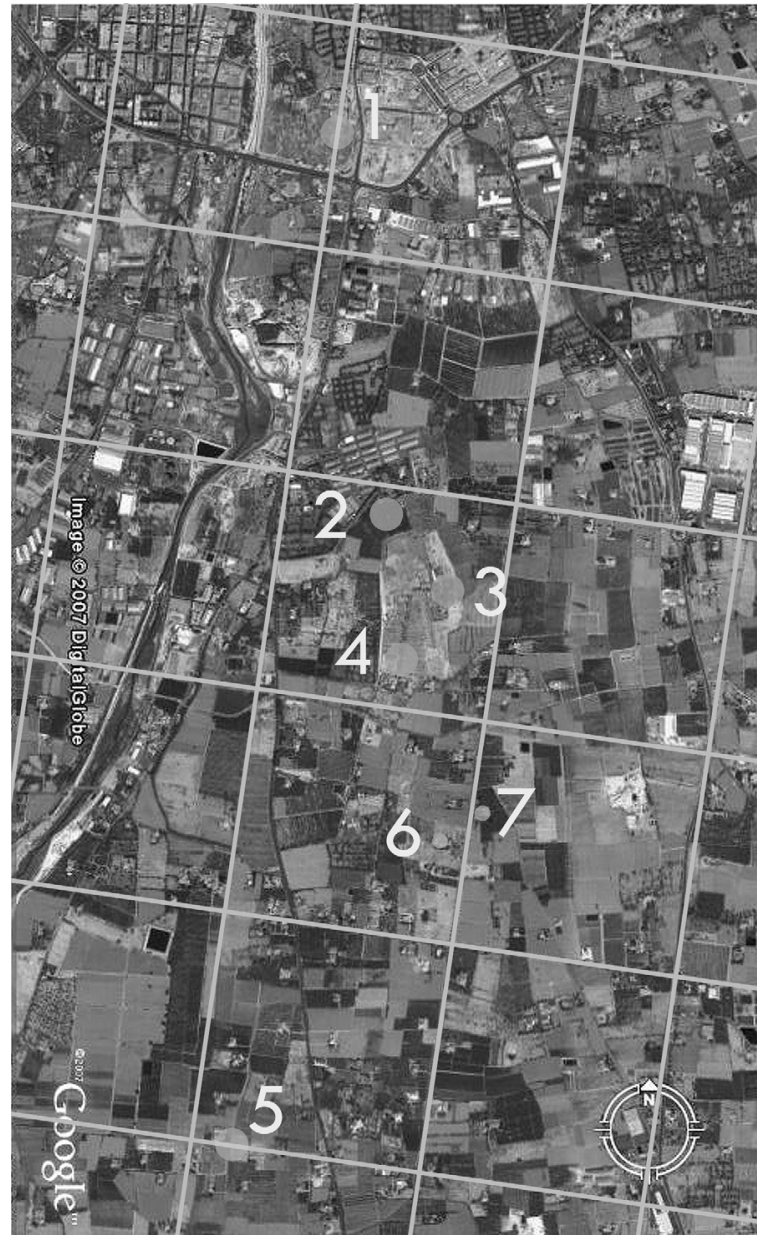

Figura 23: Fotografía aérea de las cinco necrópolis constatadas y los hallazgos aislados más próximos a l'Alcúdia d'Elx. 1: Necrópolis del Campo de Experimentación Agrícola; 2: $\mathrm{Ne}$ crópolis del Torrero; 3: Necrópolis del Borrocat; 4: Necrópolis de la basílica; 5: Necrópolis del Tio Peix; 6: Tumba en $\mathrm{H}^{\mathrm{a}}$ de R. Irles; y 7: Tumba en $\mathrm{H}^{\mathrm{a}}$ de Porter.

año 1935, hizo algunas calicatas en los alrededores del cementerio de aquella localidad, encontrando cuatro sepulturas que fueron clasificadas por dicho señor como pertenecientes al período visigótico" (Ramos, 1953, 353), si bien Paul Reynolds (1993, 55-56) encuadra dichas tumbas con otra también ubicada al oeste del cementerio viejo de Santa Pola que data en la primera mitad del siglo III.

\section{CONCLUSIONES}

A partir de la arqueología bibliográfica -feliz expresión acuñada por Jesús Moratalla a la hora de tratar de la realidad de l'Alcúdia ibérica (vid. Lucentum, 2005)-, este trabajo deduce y recupera unas 85 inhumaciones correspondientes a la
Ilici tardía (Fig. 24 a y b) ${ }^{57}$, entendida ésta como la vieja ciudad romana y el territorio circundante. Dejando a un lado los hallazgos aislados, algunos de ellos, como las sepulturas de la calle Velarde, de cierta entidad, la mayoría de tumbas puede agruparse en cinco necrópolis dentro de un radio de $1500 \mathrm{~m}$ con origen en la loma de l'Alcúdia (Fig. 23), dos de ellas claramente intramuros y alterando tanto el urbanismo anterior como los principios legales y culturales clásicos.

La necrópolis de incineración altoimperial del Torrero, ubicada extramuros en las proximidades de la puerta norte de llici o, al menos, en el tramo final del cardo máximo de la centuriación ilicitana a su llegada a la colonia, una via que conocía otra necrópolis de incineración a escasos $1000 \mathrm{~m}$ al norte de la loma, evolucionó a una de inhumación entre los siglos III-IV al VI, casi contemporánea en tiempo y tipos de enterramiento a la gran necrópolis intramuros del Borrocat que ocupó el sector centro-oriental de la loma, alterando y amortizando una zona de hábitat anterior que había vivido importantes reformas en la segunda mitad del siglo III, y cuyas numerosas tumbas se organizaban alineadas y en torno a un monumento funerario. Quizás contemporáneo a estas dos, el conjunto menor de la necrópolis del Tio Peix se ubicaba cerca del eje que ya había visto las dos necrópolis al norte, probablemente la propia via Augusta pero ahora a $1500 \mathrm{~m}$ al sur de la loma, con una posible reutilización o monumentalización en el siglo VII, cuando el nuevo poder visigodo vió

57. Una última reflexión sobre los distintos testimonios conservados nos presenta unos primeros hallazgos siempre de gran entidad, especialmente muchos sarcófagos monolíticos o formados con sillares. Avanzado el siglo $X X$ se descubren numerosas sepulturas formadas de mampostería o lajas de piedra y cubiertas también por losas más o menos trabajadas. Pero, salvo los casos recuperados cerca de la basílica en 1950, no es hasta los primeros años del siglo $\mathrm{XXI}$ que se documentan las primeras fosas simples sin cubierta ni paredes de piedra o señalización alguna, y a una de ellas la cuchara de la pala le arrancó el cráneo mientras que de la otra apenas se sabe más que su aparición en un relleno. De no haber sido tan llamativos los sarcófagos que las remociones de tierra y plantaciones de finales del siglo XIX pusieron al descubierto en l'Alcúdia, ¿se habría enterado Pere lbarra? Sólo aparecieron sarcófagos, ¿o bien los restos de tumbas "de menor entidad" pasaron desapercibidos para los hombres que, azada en mano, trabajaban aquella loma llena de piedras raras? $Y$ cuando excavaciones posteriores han constatado tantas sepulturas construídas con losas, ¿cuántos enterramientos en fosa simple no habrán pasado desapercibidos ante las nuevas generaciones de trabajadores? ¿Cuántas sepulturas no se habrán perdido ya en la loma para la investigación histórica? Y... ¿cuántas más aparecerán?. 
Total aproximado: 85

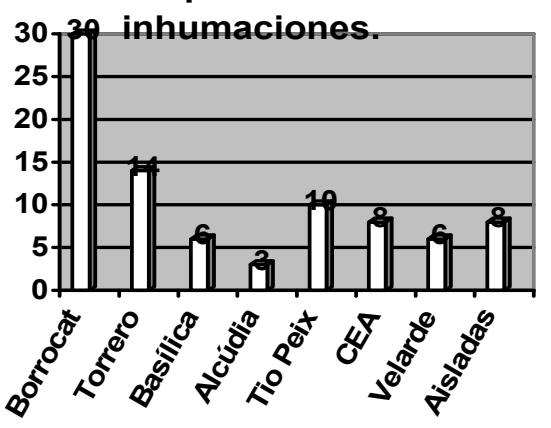

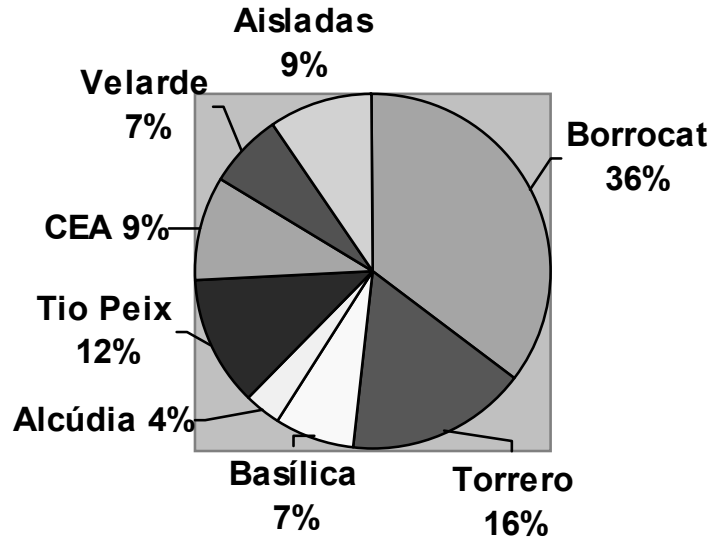

Figura 24 a y b: Distribución absoluta y porcentual de las sepulturas tardías de Ilici recuperadas en este trabajo.

surgir, o quizá crecer, otra necrópolis intramuros, ahora ad sanctos de la vieja basílica pavimentada de mosaico que vivía reformas internas en ese momento. Con la dominación islámica, a caballo de la desaparición urbana de llici y la aparición de la IIš medieval, se recuperó la antigua necrópolis septentrional de incineración del Campo de Experimentación Agrícola y las inhumaciones laterales del nuevo rito compartieron el viejo espacio de las urnas enterradas.

\section{NOTA}

Las figuras $1,2,3,4,14$ y 16 son croquis de los diarios de A. Ramos. La 5, 8, 12, 13 y 15 son fotografías suyas, y la 22 de P. Ibarra, todo ello conservado en el AFA y consultado por cortesía de sus descendientes y de la FUIA «La Alcudia». La 6 es parte de una planta cedida por el Instituto Arqueológico Alemán de Madrid, mientras que la $7 a$ y b son fotografías de Th. Hauschild allí conservadas (D-DAI-MAD-R-213A-71-12 y D-DAI-MAD-R-214-71-01). La 17 es una fotografía cedida por Alebus SL. La 10 ya la publicó A. Ibarra (1879, lámina xiii), la 18 R. González Villaescusa $(2001,403)$, la 19 M.D. Sánchez de Prado (2004, 218-221), y la 20 y 21 A. Ramos (1956, lámina CIX). Finalmente, la 9, sobre una base cartográfica facilitada por Ignacio Grau, 23 y 24 son creación, y la 11 fotografía, del autor.

Roberto Lorenzo de San Román
Passeig de Fora Muralla, 12
17004 Girona
rlaurentius@gmail.com

\section{BIBLIOGRAFÍA}

ABAD CASAL, L. y ABASCAL PALAZÓN, J.M., 2003: "Las necrópolis" y "Ritos funerarios paganos" en Romanos y visigodos en tierras valencianas, 245-257, València.

ABAD CASAL, L. y HERNÁNDEZ PÉREZ, M., 2004 (coords.): Iberia, Hispania, Spania. Una mirada desde llici, Alicante.

ABAD CASAL, L., MORATALLA JÁVEGA, J. y TENDERO PORRAS, M., 2000: "Contextos de Antigüedad Tardía en las Termas Occidentales de La Alcudia (Elche, Alicante)",
Anales de Prehistoria y Arqueología de la Universidad de Murcia, 16, 133-147.

ABASCAL PALAZÓN, J.M., 1991: "La muerte en Roma: fuentes, legislación y evidencia arqueológica", Arqueología de la muerte: metodología y perspectivas actuales [Fuenteovejuna, 1990], 205-245, Córdoba.

ABASCAL PALAZÓN, J.M., 2004: "Colonia Iulia llici Augusta", Iberia, Hispania, Spania. Una mirada desde Ilici, 79-94, Alicante.

ALBERTINI, E., 1906: "Fouilles d'Elche”, Bulletin Hispanique, VIII, n.4, 333-362.

ALBERTINI, E., 1907: "Fouilles d'Elche (Suite et fin)", Bulletin Hispanique, IX, n.2, 109-127.

ALBIACH DELSCALS, R. y SORIANO SÁNCHEZ, R., 1996a: "El cementerio romano meridional: Nuevos y viejos datos", Saitabi, 46, Dossier: Necròpolis valencianes, 101-122.

ALBIACH DELSCALS, R. y SORIANO SÁNCHEZ, R., 1996b: "El cementerio romano de Orriols", Saitabi, 46, Dossier: Necròpolis valencianes, 123-145.

AMANTE SÁNCHEZ, M. y GARCÍA BLÁNQUEZ, L., 1990: "La necrópolis tardorromana de la Molineta, Puerto de Mazarrón (Murcia). Calle Santa Teresa, n.36-38", Arte y Poblamiento en el SE Penínsular durante los últimos siglos de civilización romana: Rafael Méndez Ortiz in memoriam. Antigüedad y Cristianismo, V, 449-470.

ANTOLINOS MARÍN, J.A. y VICENTE SÁNCHEZ, J.J., 2000: "La necrópolis tardoantigua de El Corralón (Los Belones, Cartagena)", V Reunió d'Arqueologia Paleocristiana Hispànica [Cartagena, 1998], 323-332, Barcelona.

ARCE MARTÍNEZ, J., 1988: Funus imperatorum. Los funerales de los emperadores romanos. Madrid.

ARCE MARTÍNEZ, J., 2005: Bárbaros y romanos en Hispania (400-507 A.D.), Madrid.

BERROCAL CAPARRÓS, M.C. y LAIZ REVERTE, M.D., 1995: "Tipología de enterramientos en la necrópolis de San Antón en Cartagena", IV Reunió d'Arqueologia Paleocristiana Hispànica [Lisboa, 1992], 173-182, Barcelona.

CASTAÑO GARCÍA, J., 2002: Els germans Aurelià i Pere Ibarra. Cent anys en la vida cultural d'Elx (1834-1934), Alicante.

GARCÍA BELLIDO, A., 1973: "Sarcófagos visigodos de Arjonilla”. XII Congreso Nacional de Arqueología [Jaén, 1971], Zaragoza.

GISBERT SANTONJA, J., 1986: "Las cerámicas de cronología visigoda en las necrópolis del País Valenciano". II Coloquio sobre Cerámica Medieval del Mediterraneo Occidental [Toledo, 1981], 207-215, Madrid. 
GODOY FERNÁNDEZ, C., 1995: Arqueología y liturgia. Iglesias hispánicas (siglos IV al VIII). Colección Publicacions de la Universitat de Barcelona, 12, Barcelona.

GODOY FERNÁNDEZ, C., 2005: "Les ciutats d'Hispania sota la protecció dels sants màrtirs. Transformacions del concepte espai religiós entre l'antiguitat tardana i l'edat mitjana”. VI Reunió d'Arqueologia Cristiana Hispànica. Les ciutats tardoantigues d'Hispania: Cristianització i topografia [València, 2003], 63-72, Barcelona.

GONZÁLEZ VILLAESCUSA, R., 2001: El mundo funerario romano en el País Valenciano. Monumentos funerarios $y$ sepulturas entre los siglos I a. de C. - VII d. de C, MadridAlicante.

GONZÁLEZ VILLAESCUSA, R., 2003: "La arqueología funeraria en las necrópolis del levante peninsular", Cursos sobre el patrimonio histórico, 7, [Reinosa, 2002], 249-266, Santander.

GOZÁLVEZ PÉREZ, V., 1974: "La centuriatio de Ilici". Estudios sobre centuriaciones romanas en España, 101-113, Madrid.

GURT ESPARRAGUERA, J.M. y RIBERA LACOMBA, A., 2005 (coords.): VI Reunió d'Arqueologia Cristiana Hispànica. Les ciutats tardoantigues d'Hispania: Cristianització i topografia [València, 2003], Barcelona.

GUTIÉRREZ LLORET, S., 1988: "El poblamiento tardorromano en Alicante a través de los testimonios materiales. Estado de la cuestión y perspectivas", Arte y Poblamiento en el SE Penínsular durante los últimos siglos de civilización romana: Rafael Méndez Ortiz in memoriam, Antigüedad y Cristianismo, V, 323-337.

GUTIÉRREZ LLORET, S., 1998: "Ciudades y conquista: el fin de las civitates visigodas y la génesis de las mudûn islámicas del sureste de Al-Andalus", Genèse de la ville islamique en Al-Andalus et au Maghreb occidental, 13757, Madrid.

GUTIÉRREZ LLORET, S., 2004: "Ilici en la Antigüedad Tardía. La ciudad evanescente”, Iberia, Hispania, Spania. Una mirada desde Ilici, 95-110, Alicante.

IBARRA MANZONI, A., 1879: Illici, su situación y antigüedades... Ed. Antonio Reus. Alicante. [Ed.facsímil 1981, Institut d'Estudis Alacantins, II, 14, Alicante].

IBARRA RUIZ, P., 1906: "Antigua basílica de Elche", Boletín de la Real Academia de la Historia, XIXL, 119-132.

IBARRA RUIZ, P., 1926: Elche, materiales para su historia. Ensayo demostrativo de su antigüedad e importancia histórica, Ed.Ruíz de Lara-Ajuntament d'Elx, Cuenca.

LÓPEZ CAMPUZANO, M. y AMANTE SÁNCHEZ, M., 1991: "La necrópolis de la Molineta: aproximación a la historia social y económica en el puerto de Mazarrón (Murcia) durante la Antigüedad Tardía", Arte, Sociedad, Economía y Religión durante el Bajo Imperio y la Antigüedad Tardía: Homenaje al Profesor Dr. D. José Blázquez Martínez al cumplir 65 años, Antigüedad y Cristianismo, VIII, 471496.

LÓPEZ VILAR, J., 2006: Les basiliques paleocristianes del suburbi occidental de Tarraco. El temple septentrional i el complex martirial de Sant Fructuós, 2 vols, Serie Documenta, 4, Tarragona.

LÓPEZ SEGUÍ, E., GÓMEZ MARTÍNEZ, M.I., PASTOR MIRA, A., TENDERO FERNÁNDEZ, F. y TORREGROSA GIMÉNEZ, P., 2004: "Elche medieval: La evolución de su sistema defensivo", De la medina a la vila: Actas II Jornadas de Arqueología Medieval [Petrer-Novelda, 2003], 33-58, Alicante.

LORENZO DE SAN ROMÁN, R., 2005: "La basílica-sinagoga de l'Alcúdia d'Elx (1905-2005). Problemes i estat de la qüestió 100 anys després", Lucentum, XXIII-XIV, 127-155.
LORENZO DE SAN ROMÁN, R., 2006: L'Alcúdia d'Elx a l'antiguitat tardana: Anàlisi historiogràfica $i$ arqueològica de l'llici dels segles V-VIII, Alicante.

MÁRQUEZ VILLORA, J.C., 1996: "La cristianización preislámica de las comarcas alicantinas. Balance y estado de la cuestión", El espacio religioso y profano en los territorios urbanos de Occidente (siglos V-VII) [La Sede de Elo. 1400 años de su fundación, Elda, 1991], 375-395.

MÁRQUEZ VILLORA, J.C. y POVEDA NAVARRO, A., 2000: "Espacio religioso y cultura material en llici (ss.IV-VII dC)". V Reunió d'Arqueologia Paleocristiana Hispànica [Cartagena, 1998], 185-198, Barcelona.

MOLINA VIDAL, J. y POVEDA NAVARRO, A., 1995: "El nivel de abandono de un sector del foro de Ilici", XXIII Congreso Nacional de Arqueología [Elche, 1994], 141-154, Elche.

MORALES SAN MARTÍN, B., 1888: "Sepulcro romamo (sic) en Illici”, El Archivo, II, 111-113.

NOLLA BRUFAU, J.M., 1995: "Els cementiris tardo-antics de la Neàpolis emporitana”, IV Reunió d'Arqueologia Paleocristiana Hispànica [Lisboa, 1992], 99-105, Barcelona.

PALOL SALELLAS, P. De, 1967: Arqueología cristiana de la España romana. Siglos IV-VI, Madrid-Valladolid.

POVEDA NAVARRO, A., 2000: "El obispado de llici", Los origenes del cristianismo en Valencia y su entorno, Grandes temas arqueológicos, 2, 85-92.

POVEDA NAVARRO, A., 2005: "Aproximación al urbanismo de Ilici Augusta durante la Antigüedad tardía”, VI Reunió d'Arqueologia Cristiana Hispànica. Les ciutats tardoantigues d'Hispania: Cristianització $i$ topografia [València, 2003], 323-341, Barcelona.

PRIEUR, J., 1986: La mort dans l'antiquité romaine, Rennes.

PUERTAS TRICAS, R., 1975: Iglesias hispánicas (siglos IV al VIII). Testimonios literarios, Colección Temas de Arte, Madrid.

RAMOS FERNÁNDEZ, R., 1975: La ciudad romana de Illici. Institut d'Estudis Alacantins, II-8. Alicante.

RAMOS FERNÁNDEZ, R., 1995: "Noticia sobre la basílica paleocristiana de Illici”, XXI Congreso Nacional de Arqueología [Teruel, 1991], 1231-1233, Zaragoza.

RAMOS FOLQUÉS, A., 1953: "Mapa arqueológico del término municipal de Elche (Alicante)", Archivo Español de Arqueología, XXVI, 323-354.

RAMOS FOLQUÉS, A., 1955: "Elche (Alicante). La Alcudia (Campañas 1940 a 1948)". Noticiario Arqueológico Hispánico, II, 107-133.

RAMOS FOLQUÉS, A., 1956: "Memoria de las excavaciones practicadas en La Alcudia de Elche (Campañas 1949 a 1952)", Noticiario Arqueológico Hispánico, III i IV, 102-113

RAMOS FOLQUÉS, A., 1958: "Unos pozos manantiales de época romana en la Alcudia de Elche", Archivo Español de Arqueología, XXXVI, p.234-249.

RAMOS FOLQUÉS, A., 1962: "Excavaciones en La Alcudia. Memoria de las Campañas 1953 a 1958”, Noticiario Arqueológico Hispano, V (1956-61), 91-97.

RAMOS FOLQUÉS, A., 1970: Historia de Elche, vol.I, Elche.

RAMOS FOLQUÉS, A., 1972: "Un cancel visigodo en La Alcudia de Elche", Pyrenae, 8, 167-172.

RAMOS FOLQUÉS, A., 1974: El cristianismo en Elche, 22, Alicante.

RAMOS FOLQUÉS, A. y RAMOS FERNÁNDEZ, R., 1976: Excavaciones en La Alcudia de Elche durante los años (1968 a 1973), Excavaciones Arqueológicas en España, 91, Madrid.

RAMOS MOLINA, A., 1997: La Planimetría del yacimiento de La Alcudia de Elche, Alicante.

RAMOS MOLINA, A. y TENDERO PORRAS, M., 2000: "Dos nuevos conjuntos termales en Ilici (La Alcudia, Elche)", 
Termas romanas en el Occidente del Imperio [Gijón, 1999], 245-250, Gijón.

RAMOS SÁINZ, M.L., 2003: "Las prácticas funerarias en la Hispania romana. Síntesis de su ritual", Cursos sobre el patrimonio histórico, [Reinosa, 2002], 7, 175-205, Santander.

REYNOLDS, P., 1993: Settlement and pottery in the Vinalopó Valley (Alicante, Spain), a.d. 400-700, British Archaeological Reports Internacional Series, n.588, Tempvs Reparatvm, Oxford.

RIBERA LACOMBA, A. y SORIANO SÁNCHEZ, R., 1996 "Los cementerios de época visigoda", Saitabi, 46, Dossier: Necròpolis valencianes, 195-230.

RIPOLL LÓPEZ, G., 1996: "La arquitectura funeraria de Hispania entre los siglos $\mathrm{V}$ y VIII: Aproximación tipológica", Spania. Estudis d'Antiguitat Tardana oferts en homenatge al profesor Pere de Palol i Salellas, Publicacions de l'Abadia de Montserrat, Sèrie II-lustrada, 12, 215-224, Barcelona.

ROSSELLÓ MESQUIDA, M. y RUIZ VAL, E., 1996: "La necrópolis occidental de la Valencia Romana”, Saitabi, 46, Dossier: Necròpolis valencianes, 147-168.

SÁNCHEZ DE PRADO, M.D., 1984: "El vidrio romano en la provincia de Alicante", Lucentum, III, 79-100.

SÁNCHEZ DE PRADO, M.D., 2004: "El vidrio en llici. La funcionalidad del objeto". Iberia, Hispania, Spania. Una mirada desde llici, 213-222, Alicante.

SCHLUNK, H., 1948: "El arte de la época paleocristiana en el Sudeste Español. La sinagoga de Elche y el martyrium de
La Alberca", III Congreso Arqueológico del Sudeste español [Murcia, 1947], 335-379, Murcia.

SCHLUNK, H. y HAUSCHILD, Th., 1978: Hispania Antiqua. Die Denkmäler der frühchristlichen und westgotischen Zeit, Madrid.

SEGURA HERRERO, G. y TORDERA GUARINOS, F., 1999: "La Antigüedad tardía en la cuenca del río Vinalopó (Alicante): El panorama funerario de los siglos V-VII dC.", XXIV Congreso Nacional de Arqueología [Cartagena, 1997], vol.IV, 531-542, Murcia.

SORIANO SÁNCHEZ, R., 1989: "La Necrópolis de la Boatella: Elementos para su cronología", Saguntum, 22, 393-411.

SORIANO SÁNCHEZ, R., 1996: "Las necrópolis bajo-imperiales. Nuevas aportaciones", Saitabi, 46, Dossier: Necròpolis valencianes, 169-179.

TENDERO FERNÁNDEZ, F. y PASTOR MIRA, A., 2003 (Eds.): $C D$ Actuaciones arqueológicas en la Provincia de Alicante 2002, Alicante.

TENDERO FERNÁNDEZ, F., GUARDIOLA MARTÍNEZ, A y PÉREZ GARCÍA, A., 2004 (Eds.): CD Actuaciones arqueológicas en la Provincia de Alicante 2003, Alicante.

TENDERO PORRAS, M. y LARA VIVES, G., 2004: "Urbanismo". Iberia, Hispania, Spania. Una mirada desde Ilici, 125-132 Alicante.

TOYNBEE, J.M.C., 1971: Death and burial in the roman world, Londres.

VIVES GATELL, J., MARÍN MARTÍNEZ, T. y MARTíNEZ DÍEZ, G. 1963: Concilios visigóticos e hispanorromanos, Barcelona-Madrid. 